\title{
An Autoantigen Profile of Human A549 Lung Cells Reveals Viral and Host Etiologic Molecular Attributes of Autoimmunity in COVID-19
}

Julia Y. Wang ${ }^{1 *}$, Wei Zhang ${ }^{2}$, Michael W. Roehrl ${ }^{1}$, Victor B. Roehrl ${ }^{1}$, and Michael H. Roehrl ${ }^{3,4 *}$

${ }^{1}$ Curandis, New York, USA

${ }^{2}$ Department of Gastroenterology, Affiliated Hospital of Guizhou Medical University, Guizhou, China

${ }^{3}$ Department of Pathology and ${ }^{4}$ Human Oncology and Pathogenesis Program, Memorial Sloan Kettering Cancer Center, New York, USA

*Correspondence: julia@curandis.com, roehrlm@mskcc.org

Running title: Autoantigen Profile and Autoimmunity in COVID-19

Keywords: COVID-19, autoimmunity, autoantigens, lung 


\section{Abstract}

We aim to establish a comprehensive COVID-19 autoantigen atlas in order to understand autoimmune diseases caused by SARS-CoV-2 infection. Based on the unique affinity between dermatan sulfate and autoantigens, we identified 348 proteins from human lung A549 cells, of which 198 are known targets of autoantibodies. Comparison with current COVID data identified 291 proteins that are altered at protein or transcript level in SARS-CoV-2 infection, with 191 being known autoantigens. These known and putative autoantigens are significantly associated with viral replication and trafficking processes, including gene expression, ribonucleoprotein biogenesis, mRNA metabolism, translation, vesicle and vesicle-mediated transport, and apoptosis. They are also associated with cytoskeleton, platelet degranulation, IL-12 signaling, and smooth muscle contraction. Host proteins that interact with and that are perturbed by viral proteins are a major source of autoantigens. Orf3 induces the largest number of protein alterations, Orf9 affects the mitochondrial ribosome, and they and $E, M, N$, and Nsp proteins affect protein localization to membrane, immune responses, and apoptosis. Phosphorylation and ubiquitination alterations by viral infection define major molecular changes in autoantigen origination. This study provides a large list of autoantigens as well as new targets for future investigation, e.g., UBA1, UCHL1, USP7, CDK11A, PRKDC, PLD3, PSAT1, RAB1A, SLC2A1, platelet activating factor acetylhydrolase, and mitochondrial ribosomal proteins. This study illustrates how viral infection can modify host cellular proteins extensively, yield diverse autoantigens, and trigger a myriad of autoimmune sequelae. 


\section{Introduction}

To gain better understanding of the transient and chronic autoimmune symptoms caused by SARS-CoV-2 infection, we have embarked on an endeavor to establish a comprehensive autoantigenome for COVID19. In a previous study, we identified a repertoire of autoantigens (autoAgs) from human fetal lung fibroblast HFL1 cells that are strongly tied to neurological and diverse autoimmune symptoms of COVID19 (1). In this study, we aim to identify additional autoAgs from human lung epithelium-like A549 cells, an adenocarcinoma cell line that is frequently used as a model host in SARS-CoV-2 infection studies.

AutoAgs were identified based on the unique affinity between autoAgs and the glycosaminoglycan dermatan sulfate (DS) that we have discovered $(2,3)$. AutoAgs and DS form affinity complexes that can engage strong dual BCR signaling in autoreactive B1 cells to induce autoantibody production (4). Hence, any self-molecule capable of forming affinity complexes with DS has a high propensity to become autoantigenic. This unifying mechanism of autoantigenicity explains how seemingly unrelated selfmolecules can all induce autoimmune B cell responses via a similar immunological signaling event. Based on DS-autoAg affinity, we have cataloged several hundred autoAgs from various cells and tissues (1, 5-7).

COVID-19 is accompanied by a wide range of autoimmune symptoms, including multisystem inflammatory syndrome in children, immune thrombocytopenic purpura, antiphospholipid syndrome, autoimmune cytopenia, immune-mediated neurological syndromes, Guillain-Barré syndrome, connective tissue disease-associated interstitial lung disease, autoimmune hemolytic anemia, autoimmune encephalitis, systemic lupus erythematosus, optic neuritis and myelitis, and acquired hemophilia (8-15). Numerous autoantibodies have been identified in COVID patients, including the classical ANA (antinuclear antibody) and ENA (extractable nuclear antigen) that are hallmarks of systemic autoimmune diseases, as well as others such as anti-neutrophil cytoplasmic antibody, lupus anticoagulant, antiphospholipid, anti-IFN, antimyelin oligodendrocyte glycoprotein, and anti-heparin-PF4 complex antibodies (8-15).

SARS-CoV-2, or viruses in general, are opportunistic intracellular pathogens that rely on the host for replication and survival. They hijack the host transcription and translation machinery for their replication, they compromise the host immune defense to evade destruction, and they modulate the host cell cycle and apoptosis for symbiosis. These viral processes are accomplished through extensive modification of host cellular components, which also results in changes in self-molecules and the emergence of autoAgs. In our previous studies, we reported that self-molecules derived from apoptotic cells display strong 
affinity to DS, becoming a major source of autoAgs $(2,3)$. In this study, we report several important molecular mechanisms in SARS-CoV-2 infection that change host self-molecules to autoAgs, including direct interaction with viral components, perturbation by viral protein expression, and post-translational protein modification by ubiquitination and phosphorylation from viral infection.

\section{Results and Discussion}

\section{A putative $A 549$ autoantigenome identified by DS-affinity}

By DS-affinity fractionation and mass spectrometry sequencing, we identified a global putative autoantigenome of 348 proteins from A549 cellular protein extracts, with 214 protein having strong affinity and 134 having intermediate affinity (Table 1). To find out whether these DS-affinity proteins are known autoAgs, we conducted an extensive literature search and confirmed that 198 (56.0\%) proteins are known humoral autoAgs, with their specific autoantibodies reported in a wide spectrum of autoimmune diseases and cancers (see autoAg confirmatory references in Table 1). The remaining 150 proteins may be yet-to-be discovered putative autoAgs and await further investigation. For example, many ribosomal proteins are known autoAgs, but the 24 mitochondrial ribosomal proteins we identified have not yet been reported as autoAgs; given their structural similarity to ribosomal protein autoAgs, it is highly likely that mitochondrial proteins are a group of undiscovered autoAgs.

The 348 DS-affinity proteins are highly connected (Fig. 1). They exhibit 6,271 interactions, whereas a random set of 348 proteins is expected to have 2,536 interactions, as revealed by protein-protein interaction STRING analysis (16). The tight connections suggest that these known and putative autoAgs are originating from common biological pathways or processes. Our analysis shows that they are indeed predominantly associated with translation, mRNA metabolic process, ribonucleoprotein complex biogenesis, vesicle and vesicle-mediated transport, chromosome, and cytoskeleton (Fig. 1).

\section{COVID-altered proteins among the A549 autoantigenome}

To find out whether the known and putative autoAgs identified by DS-affinity may play a role in SARSCoV-2 infection, we compared our A549 autoantigenome with currently available COVID data compiled in the Coronascape database (17-37). Of our 348 autoantigenome proteins from A549 cells, 291 (83.6\%) have been found to be COVID-altered, i.e., up- and/or down-regulated at protein and/or mRNA level in SARS-CoV-2 infected cells or patient tissues (Table 1). Because the COVID data have been generated from 
various research labs using different techniques and sources of cells or tissues, 190 proteins are found to be up in some studies but down in others. In total, 231 proteins are found up-regulated, and 252 are found down-regulated in SARS-CoV-2 infection. Based on reported autoantibodies, 191 (65.6\%) COVID-altered proteins are confirmed autoAgs (Table 1 ).

Based on gene ontology (GO) cellular component analysis, proteins of the A549 DS-affinity autoantigenome that are also altered in COVID infection can be located to membrane-bound organelles (247 proteins), nucleus (177 proteins), ribonucleoprotein complex (95 proteins), mitochondrion (46 proteins), endoplasmic reticulum (45 proteins), secretory granules (41 proteins), melanosome (27 proteins), myelin sheath (28 proteins), and axon (16 proteins).

Within the total A549 autoantigenome, the 291 COVID-altered proteins form a tightly interacting network (Fig. 2). At high STRING protein-protein interaction confidence level, these proteins exhibit 2,249 interactions, whereas 953 interactions would be expected of a random collection of proteins of the same size. By GO biological process analysis, the COVID-altered proteins are significantly enriched in various biological processes, including translation, peptide biosynthetic process, RNA catabolic process, nucleobase-containing compound catabolic process, SRP-dependent cotranslational protein targeting to membrane, protein localization to organelle, and symbiont process. Among these processes associated with COVID-altered proteins, the hierarchical cluster tree root points to ribonucleoprotein complex biogenesis (Fig. 3).

Combined pathway and process enrichment analyses also show that the COVID-altered DS-affinity proteins are most significantly related to peptide biosynthetic process, metabolism of RNA, and ribonucleoprotein complex biogenesis (Fig. 4). The up-regulated autoAgs are more related to Nop56passociated pre-rRNA complex, RNA catabolic process, and vesicle-mediated transport, whereas the downregulated autoAgs are more related to translation and ribosome biogenesis. COVID-altered autoAgs are also significantly associated with regulated exocytosis, platelet degranulation, smooth muscle contraction, and IL-12 signaling.

The molecular functions of the COVID-altered DS-affinity autoAgs include RNA binding (76 proteins), hydrolase activity (58 proteins), purine ribonucleotide triphosphate binding (55 proteins), pyrophosphatase activity (35 proteins), nucleoside-triphosphatase activity (34 proteins), oxidoreductase 
activity (26 proteins), ATPase activity ( 25 proteins), ubiquitin protein ligase binding (21 proteins), mRNA 3'-UTR binding (11 proteins) and 5'-UTR binding ( 3 proteins), and helicase activity (13 proteins).

\section{AutoAgs that interact with SARS-CoV-2 proteins}

To study the origins of COVID-induced autoAg alterations, we examined DS-affinity proteins that are involved in the interactomes of SARS-CoV-2 viral proteins $(19,30,34)$ and found 38 DS-affinity proteins that interact directly with different viral proteins, with 25 of them being known autoAgs, e.g., ATP5B, CANX, DDX21, EEF1A2, PDIA3, and SLC2A1 (Table 1). Orf3 protein is the most striking, as its interactome includes 14 DS-affinity proteins and 9 known autoAgs. $N$ protein interacts with 9 DS-affinity proteins and 6 known autoAgs, including 2 helicases (DDS21 and MOV10), 2 poly(A)-binding proteins (PABPC1 and PABPC4). Nsp4 interact with 6 DS-affinity proteins and 5 known autoAgs. Nsp4 interacts with IDE (insulin degrading enzyme), which is not a known autoAg.

A few host DS-affinity proteins interact with more than one SARS-CoV-2 protein. RAB1A (involved in intracellular membrane trafficking) interacts with 3 viral proteins (Orf3, Orf7b, and Nsp7), and PLD3 (phospholipase) also interacts with 3 viral proteins (Nsp2, Orf7b, and Orf8), but neither RAB1A nor PLD3 has been discovered as autoAgs. HSPA5 (GRP78/BiP) interacts with Nsp2 and Nsp4, HSPA1A interacts with $\mathrm{N}$ and Orf9b, and both heat shock proteins are known autoAg. PRKDC, a known autoAg, interacts with $\mathrm{M}$ and Nsp. Interestingly, of the ezrin-radixin-moesin protein family that connects the actin cytoskeleton to the plasma membrane, RDX is found to interact with Orf3 and Nsp13, MSN interacts with Orf3 and Nsp6, and EZR is COVID-altered. Furthermore, RDX, MSN, and EZR are all known autoAgs (Table 1).

\section{AutoAgs from perturbation by viral protein expression}

To find out how individual SARS-CoV-2 proteins affect the host, Stukalov et al. conducted extensive proteomic analysis of A549 cells transduced to express individual SARS-CoV-2 proteins (34). By comparing with their data, we identified 167 DS-affinity proteins that are perturbated by viral protein expression in A549 cells. Among all SARS-CoV-2 proteins, Orf3 expression produced the largest number of potential autoAgs, with 26 up- and 36 down-regulated being DS-affinity proteins (Fig. 5, Supplemental Table 1). Other viral protein expressions affected various numbers of DS-affinity proteins, including E (20 up and 18 down), Orf9b (6 up and 16 down), M (10 up and 11 down), N (10 up and 8 down), Nsp13 (5 up and 11 down), and Nsp12 (3 up and 12 down). Interestingly, S expression yielded only 3 up- and 2 down-regulated DS-affinity proteins, suggesting that it may not have much intracellular activity. 
In total, Orf3 affected 71 DS-affinity proteins identified from A549 cells, which includes those directly interacting with Orf3 and those perturbed by Orf3 protein expression in A549 cells. The large number of Orf3-affected host proteins implicates important roles of Orf3 in SARS-CoV-2 infection. Network analysis reveals these proteins to be mostly associated with gene expression regulation, cytoplasmic vesicles, apoptosis, response to stress, monosaccharide biosynthesis, or hydrolase activity (Fig. 5). Several of these are classical nuclear autoAgs, e.g., PNCA, SSB (Lupus La), XRCC5 (Lupus Ku80, thyroid-lupus autoAg), XRCC6 (Ku70), and SNRPB (SmB/B'). A few are unknown autoAgs but with important relevance to COVID, e.g., PAFAH1B2 and PAFAH1B3 (the alpha catalytic subunits of the cytosolic type I platelet-activating factor (PAF) acetylhydrolase). PAF is produced by a variety of cells involved in host defense, and PAF signaling can trigger inflammatory and thrombotic cascades. The modulation of PAF by SARS-CoV-2 Orf3 may partially explain the frequently occurring thrombotic complications and coagulopathy in COVID-19 patients. PAF also induces apoptosis in a PAF receptor independent pathway that can be inhibited by PAFAH1B2 and PAFAH1B3 (38).

SARS-CoV-2 E protein affects a number of ribonucleoproteins that are related to translation initiation and mRNA splicing, e.g., hnRNP (U and UL1) and ribosomal protein (L7, L8 L11, L12, L35A). E-affected proteins are associated with establishment of protein localization to membrane, regulation of autophagy, and post-translational protein modification (Fig. 5). SARS-CoV-2 M, Nsp1, and N proteins also affect various ribonucleoproteins, whereas Nsp13 appears to affect proteins associated with the cytoskeleton. Overall, the majority of DS-affinity proteins found affected by individual SARS-CoV-2 proteins are known autoAgs (Fig. 5 and Table 1), which indicates that host proteins perturbed by viral components are an important source of autoAgs.

\section{Mitochondrial perturbation by SARS-CoV-2 Orf9b}

By DS-affinity fractionation, we identified 22 mitochondrial ribosomal proteins from A549 cells with strong DS-affinity, including mitochondrial 39S ribosomal proteins (L1, L2, L13, L15, L17, L18, L19, L23, L37, L38, L39, L45, L49) and 28 S ribosomal proteins (S9, S22, S23, S27, S28, S29, S30, S34, S39) (Table 1). Remarkably, 14 mitochondrial ribosomal proteins are found down-regulated in SARS-CoV-2 infection, with 2 (L15 and L37) reported both down- and up-regulated. Moreover, MRPS27 is found in the interactome of SAS-Cov-2 Nsp8. Most strikingly, Orf9b-expression in A549 cells caused down-regulation of 16 proteins that we identified by DS-affinity, namely, ALB, ANXA4, LAMP2, MRPL2, MRPL13, MRPL15, MRPL17, 
MRPL18, MRPL19, MRPS30, MRPL37, MRPL38, MRPL39, MRPL45, MRPL49, and UCHL1 (Fig. 5). Eleven of the Orf9-affected proteins are mitochondrial ribosomal proteins, which may affect the mitochondrial translation machinery. Orf9-affected proteins may also be involved in mitochondrion localization, autophagosome maturation, or other processes. Overall, these findings suggest that SARS-CoV-2 infection may affect mitochondria primarily through Orf9b.

Orf9b of SARS-CoV has been shown to localize to mitochondria, trigger ubiquitination and proteasomal degradation of dynamin-like protein 1 , limit host cell interferon signaling by targeting mitochondrial associated adaptor molecule MAVS signalosome, and manipulate the mitochondrial function to help evade host innate immunity (39). Orf9b of SARS-CoV-2 has been reported to suppress the type I interferon response by targeting TOM70 (40). In COVID-19 pneumonia patients, monocytes show altered bioenergetics and mitochondrial dysfunction with depolarized and abnormal ultrastructure (41).

Currently, little is known about the involvement of mitochondrial ribosomes or mitochondrial translation in SARS-CoV-2 infection. Expression of mitochondrial ribosomal proteins associated with protein synthesis has been found to be the most striking transcriptional difference among dengue virus-infected children, as revealed by a genome-wide microarray analysis of whole blood RNA from 34 infected children collected on days 3-6 of illness (42). In human cytomegalovirus infection, proteins involved in biogenesis of the mitochondrial ribosome changed early during the viral replication cycle (43). Mitochondria are vital to cell survival and apoptosis as they produce the majority of adenosine triphosphate (ATP) that provide chemical energy to cells. Especially for cells such as muscles that require much ATP, mitochondrial dysfunction will certainly lead to problems such as muscle weakness and fatigue. The roles of mitochondrial ribosomal proteins play in COVID and long-term sequelae merit further investigation.

\section{AutoAgs related to ubiquitination alteration in SARS-CoV-2 infection}

Ubiquitination provides a universal signal for protein degradation. By comparing our data with the ubiquitinome of SARS-CoV-2 infected cells, we identified 102 DS-affinity proteins that are altered by ubiquitination during viral infection (Supplemental Table 1). These ubiquitination-altered proteins are significantly associated with gene expression, catabolic process, regulation of apoptotic process, cytoplasmic vesicles, and cytoskeleton (Fig. 6). They include 15 ribosomal proteins, 8 heat shock proteins, 5 hnRNP proteins, 5 histones, 4 translation elongation factors, and 3 translation initiation factors, and a majority of them are known autoAgs (Table 1 ). 
Three ubiquitination/de-ubiquitination enzymes (UBA1, UCHL1, and USP7) are COVID-altered and possess DS-affinity, with UBA1 and UCHL1 being known autoAgs. UBA1 catalyzes the first step in ubiquitin conjugation to mark proteins for degradation through the ubiquitin-proteasome system. USP7 is a hydrolase that deubiquitinates target proteins. UCHL1 is a thiol protease that recognizes and hydrolyzes a peptide bond at the C-terminal glycine of ubiquitin, and is involved in the processing of ubiquitin precursors and of ubiquitinated proteins. UBA1 is found down-regulated by Orf3 expression. UCHL1 is found in the Orf3 interactome, up-regulated by SARS-CoV-2 E protein expression, and down-regulated by Nsp12, Nsp8, Orf8, and Orf9b (Supplemental Table 1).

Ten COVID-altered DS-affinity proteins were identified with ubiquitin protein ligase-binding activity, including HSPA1A, HSPA5, HSPA8, HSP90AA1, HSP90AB1, RPL11, VCP, VCL, YWHAE, and YWHAZ. HSPA1A interacts with SARS-CoV-2 Orf9b and N proteins, HSPA5 (GRP78/BiP) interacts with Nsp2 and Nsp4, and HSPA8 interacts with Nsp2. Except for RPL11, all are known autoAgs (Table 1).

In addition, SARS-CoV-2 and other coronaviruses encode for papain-like proteases (PLP), an important multifunctional enzyme with de-ubiquitination, de-ISGlation, and interferon antagonism activities (44). PLPs, along with other proteases, are responsible for processing replicase proteins that are required from viral replication. PLP of SARS-CoV-2 is able to reverse host ubiquitination and remove interferonstimulated gene product 15 (ISG15), and its substrate activity mirrors closely that of PLP of MERS (45). Ubiquitin modifications can regulate innate immune response and apoptosis, and ISG15 is a ubiquitin-like modifier typically expressed during host cell immune response. Overall, various components of SARS-CoV2 appear to be able to alter uniquitination of host proteins. The large pool of ubiquitin-altered proteins in SARS-CoV-2 infection indicates that ubiquitin modification, such as differential abundance and dynamic ubiquitination pattern change, may be a major origin of autoAgs.

\section{AutoAgs related to phosphorylation alteration in SARS-CoV-2 infection}

Comparing our data with currently available phosphoproteome data of COVID-19 (26, 34), 97 phosphoproteins are found with both DS-affinity and COVID-induced alteration, with a majority (52/97) related to gene expression (Fig. 7). Notably, they include 8 heterogeneous nuclear ribonucleoproteins affected by phosphorylation (HNRNPA2B1, HNRNPC, HNRNPH1, HNRNPK, HNRNPM, HNRNPU, HNRNPUL1, HNRNPUL2), with 4 being known autoAgs (Table 1). HNRNPs are involved in many cellular 
processes, including gene transcription, cell cycle, DNA damage control, post-transcriptional modification of newly synthesized pre-mRNA, and virus replication. For example, HNRNPA2B1 displays RNA-binding affinity to murine hepatitis coronavirus via binding the viral RNA at the $3^{\prime}$ end and modulate viral RNA synthesis (46).

There are 25 phosphorylation-altered proteins that are related to vesicle-mediated transport, most of which are known autoAgs, including ACLY, ACTA2, ACTB, ALB, ALDO, ANXA2, FLNA, COPA, SPTAN1, SPTBN1, TLN1, TUBB4, and VCL (Fig. 7 and Table 1). The coatomer, to which COPA (coatomer subunit alpha) belongs, is a cytosolic protein complex that associates with Golgi non-clathrin-coated vesicles and is required for budding from the Golgi membrane. COPA is associated with autoimmune interstitial lung, joint, and kidney disease (47).

There are 18 phosphorylation-altered potential autoAgs with ATP binding activity, and 12 with kinase binding activity (Fig. 7). In particular, PRKDC (DNA-dependent protein kinase catalytic subunit) is identified with strong DS-affinity and is a known autoAg. It is a serine/threonine-protein kinase that acts as a molecular sensor for DNA damage, with involvement in numerous biological processes such as DNA damage and repair, immunity, innate immunity, ribosome biogenesis, and apoptosis. PRDKC is found in the interactomes of M and Nsp4 proteins of SARS-CoV-2 and up-regulated by expression of Nsp10, Nsp9, Orf7a, or Orf7b protein in A549 cells $(19,34)$. PRKDC is also found up-regulated at $0 \mathrm{~h}$ and $4 \mathrm{~h}$ in SARSCoV-2 infected Vero E6 cells (26) and up-regulated at $24 \mathrm{~h}$ in SARS-CoV-2 infected Caco-2 cells (20). These findings suggest that phosphorylation by PRKDC plays extensive and important roles in COVID.

Proteins phosphorylated during apoptosis are common targets of autoantibodies. For example, the U170 snRNP autoAg undergoes specific changes in the phosphorylation/dephosphorylation balance and cellular localization during apoptosis (48), and phosphorylated U1-snRNP complex induced by apoptosis is recognized by autoantibodies in patients with systemic lupus erythematosus (49). A high degree of phosphorylation of SSB (lupus La autoAg) substantially diminished its poly(U) binding capacity, but its binding to human autoantibodies increased 2-fold with increased phosphorylation (50). On the other hand, SSB autoAg has also been reported to be dephosphorylated and cleaved during early apoptosis (51). During apoptosis, ribosomal protein P1 and P2 autoAgs are completely dephosphorylated while P0 autoAg is partially dephosphorylated (52). Therefore, alterations in phosphorylation, either hyper- or hypophosphorylation, may lead to changes in self-molecules and render them autoantigenic. 


\section{Conclusion}

In our quest for a comprehensive autoantigen atlas for COVID-19, we report an autoantigen profile of 191 confirmed autoAgs and 150 putative autoAgs in SARS-CoV-2 infection. These proteins are initially identified from human lung epithelial A549 cells using a unique DS-affinity autoAg enrichment strategy, and then compared with currently available COVID-omics data. Our study reveals that cellular processes and components integral to viral infection are major origins of autoAgs, including gene expression, ribonucleoprotein biogenesis, translation and mitochondrial translation, vesicle and vesicle-mediated transport, and cytoskeleton. Ubiquitination and phosphorylation are particular post-translational modifications that cause changes in self-molecules and render them autoantigenic. Impaired clearance of apoptotic and dead cell material is considered a major pathogenic attribute to autoimmune disease. We have previously shown that DS possesses unique affinity to apoptotic cells and their released autoAgs, and our current study further demonstrates that ubiquitination and phosphorylation associated with apoptosis are possibly major sources of molecular alterations in self-molecule to autoantigen transformation. Overall, our study demonstrates that SARS-CoV-2 causes extensive alterations of host cellular proteins and produces a large number of potential autoAgs, indicating that there may be an intimate relationship between COVID infection and autoimmunity. 


\section{Materials and Methods}

\section{A549 cell culture}

The A549 cell line was obtained from the ATCC (Manassas, VA, USA) and cultured in complete F-12K medium at $37{ }^{\circ} \mathrm{C}$ in $75 \mathrm{~cm}^{2}$ flasks to $80 \%$ confluency. The growth medium was supplemented with $10 \%$ fetal bovine serum and a penicillin-streptomycin-glutamine mixture (Thermo Fisher).

\section{Protein extraction}

About 100 million A549 cells were suspended in $10 \mathrm{ml}$ of $50 \mathrm{mM}$ phosphate buffer $(\mathrm{pH} 7.4)$ containing the Roche Complete Mini protease inhibitor cocktail. Cells were homogenized on ice with a microprobe sonicator until the turbid mixture turned nearly clear with no visible cells left. The homogenate was centrifuged at $10,000 \mathrm{~g}$ at $4{ }^{\circ} \mathrm{C}$ for $20 \mathrm{~min}$, and the total protein extract in the supernatant was collected. Protein concentration was measured by absorbance at $280 \mathrm{~nm}$ using a NanoDrop UV-Vis spectrometer (ThermoFisher).

\section{DS-Sepharose resin preparation}

The DS-affinity resins were prepared as previously described $(3,5)$. In brief, $2 \mathrm{ml}$ of EAH Sepharose 4B resins (GE Healthcare Life Sciences) were washed with distilled water three times and mixed with $10 \mathrm{mg}$ of DS (Sigma-Aldrich) in $1 \mathrm{ml}$ of $0.1 \mathrm{M} \mathrm{MES} \mathrm{buffer,} \mathrm{pH} \mathrm{5.0.} \mathrm{About} 20 \mathrm{mg}$ of N-(3-dimethylaminopropyl)-N'ethylcarbodiimide hydrochloride (Sigma-Aldrich) powder was added at the beginning of the reaction, and another $20 \mathrm{mg}$ was added after $8 \mathrm{~h}$ of reaction. The reaction mixture was mixed by end-over-end rotation at $25^{\circ} \mathrm{C}$ for $16 \mathrm{~h}$. The coupled resins were washed with water three times and equilibrated with a low-pH buffer (0.1 M acetate, $0.5 \mathrm{M} \mathrm{NaCl}, \mathrm{pH} 5.0)$ and a high-pH buffer (0.1 M Tris, $0.5 \mathrm{M} \mathrm{NaCl}, \mathrm{pH} 8.0$ ).

\section{DS-affinity fractionation}

The total proteins extracted from A549 cells were fractionated in a DS-Sepharose column with a BioLogic Duo-Flow system (Bio-Rad). About $40 \mathrm{mg}$ of proteins in $40 \mathrm{ml}$ of $10 \mathrm{mM}$ phosphate buffer (pH 7.4; buffer A) were loaded onto the column at a rate of $1 \mathrm{ml} / \mathrm{min}$. Unbound and weakly proteins were washed off with $60 \mathrm{ml}$ of buffer $A$ and then $40 \mathrm{ml}$ of $0.2 \mathrm{M} \mathrm{NaCl}$ in buffer $A$. The remaining bound proteins were eluted with $40 \mathrm{ml} 0.5 \mathrm{M} \mathrm{NaCl}$ and then with $40 \mathrm{ml} 1.0 \mathrm{M} \mathrm{NaCl}$ in buffer A. Fractions were desalted and concentrated to $0.5 \mathrm{ml}$ with 5-kDa cut-off Vivaspin centrifugal filters (Sartorius). Fractionated proteins were separated by 1-D SDS-PAGE in 4-12\% Bis-Tris gels, and the gel lanes were divided into two or three sections and subjected to sequencing. 


\section{Mass spectrometry sequencing}

Protein sequencing was performed at the Taplin Biological Mass Spectrometry Facility at Harvard Medical School. Proteins in gels were digested with sequencing-grade trypsin (Promega) at $4{ }^{\circ} \mathrm{C}$ for $45 \mathrm{~min}$. Tryptic peptides were separated on a nano-scale $\mathrm{C}_{18}$ HPLC capillary column and analyzed in an LTQ linear ion-trap mass spectrometer (Thermo Fisher). Peptide sequences and protein identities were assigned by matching the measured fragmentation pattern with proteins or translated nucleotide databases using Sequest. All data were manually inspected. Only proteins with $\geq 2$ peptide matches were considered positively identified.

\section{COVID data comparison}

DS-affinity proteins were compared with currently available proteomic and transcriptomic data from SARS-CoV-2 infection compiled in the Coronascape database (as of 12/14/2020) (17-37). These data had been obtained with proteomics, phosphoproteomics, interactome, ubiquitome, and RNA-seq techniques. Up- and down-regulated proteins or genes were identified by comparing COVID-19 patients vs. healthy controls and cells infected vs. uninfected by SARS-CoV-2. Similarity searches were conducted between our data and the Coronascape database to identify DS-affinity proteins (or their corresponding genes) that are up- and/or down-regulated in the viral infection.

\section{Protein-protein interaction network analysis}

Protein-protein interactions were analyzed by STRING (16). Interactions include both direct physical interaction and indirect functional associations, which are derived from genomic context predictions, high-throughput lab experiments, co-expression, automated text mining, and previous knowledge in databases. Each interaction is annotated with a confidence score from 0 to 1, with 1 being the highest, indicating the likelihood of an interaction to be true. Only interactions with high confidence (a minimum score of 0.7 ) are shown in the figures.

\section{Pathway and process enrichment analysis}

Pathways and processes enrichment were analyzed with Metascape (17), which utilize various ontology sources such as KEGG Pathway, GO Biological Process, Reactome Gene Sets, Canonical Pathways, CORUM, TRRUST, and DiGenBase. All genes in the genome were used as the enrichment background. Terms with a p-value $<0.01$, a minimum count of 3 , and an enrichment factor (ratio between the observed counts and 
the counts expected by chance) $>1.5$ were collected and grouped into clusters based on their membership similarities. The most statistically significant term within a cluster was chosen to represent the cluster. Hierarchical clustering trees were obtained with ShinyGo (53).

\section{Autoantigen confirmation literature text mining}

Literature searches in Pubmed were performed for every DS-affinity protein identified in this study. Search keywords included the protein name, its gene symbol, alternative names and symbols, and the MeSH keyword "autoantibodies". Only proteins with their specific autoantibodies reported in PubMed-listed journal articles were considered "confirmed" autoAgs in this study. 


\section{Acknowledgements and funding statement}

This work was partially supported by Curandis, the US NIH, and a Cycle for Survival Innovation Grant (to MHR). MHR acknowledges the NIH/NCI R21 CA251992 and MSKCC Cancer Center Support Grant P30 CA008748. The funding bodies were not involved in the design of the study and the collection, analysis, and interpretation of data. We thank Jung-hyun Rho for technical assistance with experiments. We thank Ross Tomaino and the Taplin Biological Mass Spectrometry facility of Harvard Medical School for expert service with protein sequencing.

\section{Competing interest statement}

JYW is the founder and Chief Scientific Officer of Curandis. WZ was supported by the NIH and declares no competing interests. MWR and VBR are volunteers of Curandis. MHR is a member of the Scientific Advisory Boards of Trans-Hit, Proscia, and Universal DX, but these companies have no relation to the study.

\section{Authors' contributions}

JYW directed the study, analyzed data, and wrote the manuscript. WZ performed some experiments and reviewed the manuscript. MWR and VBR assisted with data analysis and manuscript preparation. MHR consulted on the study and data analysis and edited the manuscript. All authors have approved the manuscript. 


\section{References}

1. Wang, J. Y., W. Zhang, M. W. Roehrl, V. B. Roehrl, and M. H. Roehrl. 2021. An Autoantigen Atlas from Human Lung HFL1 Cells Offers Clues to Neurological and Diverse Autoimmune Manifestations of COVID-19. bioRxiv 2021.01.24.427965.

2. Wang, J. Y., J. Lee, M. Yan, J. H. Rho, and M. H. Roehrl. 2011. Dermatan sulfate interacts with dead cells and regulates CD5(+) B-cell fate: implications for a key role in autoimmunity. Am J Pathol 178: 2168-2176.

3. Rho, J. H., W. Zhang, M. Murali, M. H. Roehrl, and J. Y. Wang. 2011. Human proteins with affinity for dermatan sulfate have the propensity to become autoantigens. Am J Pathol 178: 2177-2190.

4. Lee, J., J.-h. Rho, M. H. Roehrl, and J. Y. Wang. 2021. Dermatan Sulfate Is a Potential Master Regulator of IgH via Interactions with Pre-BCR, GTF2I, and BiP ER Complex in Pre-B Lymphoblasts. bioRxiv 2021.01.18.427153.

5. Wang, J. Y., W. Zhang, J. H. Rho, M. W. Roehrl, and M. H. Roehrl. 2020. A proteomic repertoire of autoantigens identified from the classic autoantibody clinical test substrate HEp-2 cells. Clinical proteomics 17: 35 .

6. Zhang, W., J. H. Rho, M. H. Roehrl, and J. Y. Wang. 2019. A comprehensive autoantigen-ome of autoimmune liver diseases identified from dermatan sulfate affinity enrichment of liver tissue proteins. BMC Immunol 20: 21.

7. Zhang, W., J. H. Rho, M. W. Roehrl, M. H. Roehrl, and J. Y. Wang. 2019. A repertoire of 124 potential autoantigens for autoimmune kidney diseases identified by dermatan sulfate affinity enrichment of kidney tissue proteins. PLoS One 14: e0219018.

8. Zhou, S., E. C. Jones-Lopez, D. J. Soneji, C. J. Azevedo, and V. R. Patel. 2020. Myelin Oligodendrocyte Glycoprotein Antibody-Associated Optic Neuritis and Myelitis in COVID-19. Journal of neuro-ophthalmology : the official journal of the North American Neuro-Ophthalmology Society 40: 398-402.

9. Bowles, L., S. Platton, N. Yartey, M. Dave, K. Lee, D. P. Hart, V. MacDonald, L. Green, S. Sivapalaratnam, K. J. Pasi, and P. MacCallum. 2020. Lupus Anticoagulant and Abnormal Coagulation Tests in Patients with Covid-19. N Engl J Med 383: 288-290.

10. Gruber, C. N., R. S. Patel, R. Trachtman, L. Lepow, F. Amanat, F. Krammer, K. M. Wilson, K. Onel, D. Geanon, K. Tuballes, M. Patel, K. Mouskas, T. O'Donnell, E. Merritt, N. W. Simons, V. Barcessat, D. M. Del Valle, S. Udondem, G. Kang, S. Gangadharan, G. Ofori-Amanfo, U. Laserson, A. Rahman, S. Kim-Schulze, A. W. Charney, S. Gnjatic, B. D. Gelb, M. Merad, and D. Bogunovic. 2020. Mapping Systemic Inflammation and Antibody Responses in Multisystem Inflammatory Syndrome in Children (MIS-C). Cell 183: 982-995.e914.

11. Gagiannis, D., J. Steinestel, C. Hackenbroch, B. Schreiner, M. Hannemann, W. Bloch, V. G. Umathum, N. Gebauer, C. Rother, M. Stahl, H. M. Witte, and K. Steinestel. 2020. Clinical, Serological, and Histopathological Similarities Between Severe COVID-19 and Acute Exacerbation of Connective Tissue Disease-Associated Interstitial Lung Disease (CTD-ILD). Front Immunol 11: 587517.

12. Lerma, L. A., A. Chaudhary, A. Bryan, C. Morishima, M. H. Wener, and S. L. Fink. 2020. Prevalence of autoantibody responses in acute coronavirus disease 2019 (COVID-19). Journal of translational autoimmunity 3: 100073.

13. Fujii, H., T. Tsuji, T. Yuba, S. Tanaka, Y. Suga, A. Matsuyama, A. Omura, S. Shiotsu, C. Takumi, S. Ono, M. Horiguchi, and N. Hiraoka. 2020. High levels of anti-SSA/Ro antibodies in COVID-19 patients with severe respiratory failure: a case-based review : High levels of anti-SSA/Ro antibodies in COVID-19. Clin Rheumatol 39: 3171-3175. 
14. Dragonetti, D., G. Guarini, and M. Pizzuti. 2020. Detection of anti-heparin-PF4 complex antibodies in COVID-19 patients on heparin therapy. Blood transfusion = Trasfusione del sangue 18: 328.

15. Bastard, P., L. B. Rosen, Q. Zhang, E. Michailidis, H. H. Hoffmann, Y. Zhang, K. Dorgham, Q. Philippot, J. Rosain, V. Béziat, J. Manry, E. Shaw, L. Haljasmägi, P. Peterson, L. Lorenzo, L. Bizien, S. Trouillet-Assant, K. Dobbs, A. A. de Jesus, A. Belot, A. Kallaste, E. Catherinot, Y. TandjaouiLambiotte, J. Le Pen, G. Kerner, B. Bigio, Y. Seeleuthner, R. Yang, A. Bolze, A. N. Spaan, O. M. Delmonte, M. S. Abers, A. Aiuti, G. Casari, V. Lampasona, L. Piemonti, F. Ciceri, K. Bilguvar, R. P. Lifton, M. Vasse, D. M. Smadja, M. Migaud, J. Hadjadj, B. Terrier, D. Duffy, L. Quintana-Murci, D. van de Beek, L. Roussel, D. C. Vinh, S. G. Tangye, F. Haerynck, D. Dalmau, J. Martinez-Picado, P. Brodin, M. C. Nussenzweig, S. Boisson-Dupuis, C. Rodríguez-Gallego, G. Vogt, T. H. Mogensen, A. J. Oler, J. Gu, P. D. Burbelo, J. I. Cohen, A. Biondi, L. R. Bettini, M. D'Angio, P. Bonfanti, P. Rossignol, J. Mayaux, F. Rieux-Laucat, E. S. Husebye, F. Fusco, M. V. Ursini, L. Imberti, A. Sottini, S. Paghera, E. Quiros-Roldan, C. Rossi, R. Castagnoli, D. Montagna, A. Licari, G. L. Marseglia, X. Duval, J. Ghosn, J. S. Tsang, R. Goldbach-Mansky, K. Kisand, M. S. Lionakis, A. Puel, S. Y. Zhang, S. M. Holland, G. Gorochov, E. Jouanguy, C. M. Rice, A. Cobat, L. D. Notarangelo, L. Abel, H. C. Su, and J. L. Casanova. 2020. Autoantibodies against type I IFNs in patients with life-threatening COVID-19. Science (New York, N.Y.) 370.

16. Szklarczyk, D., A. L. Gable, D. Lyon, A. Junge, S. Wyder, J. Huerta-Cepas, M. Simonovic, N. T. Doncheva, J. H. Morris, P. Bork, L. J. Jensen, and C. V. Mering. 2019. STRING v11: protein-protein association networks with increased coverage, supporting functional discovery in genome-wide experimental datasets. Nucleic Acids Res 47: D607-D613.

17. Zhou, Y., B. Zhou, L. Pache, M. Chang, A. H. Khodabakhshi, O. Tanaseichuk, C. Benner, and S. K. Chanda. 2019. Metascape provides a biologist-oriented resource for the analysis of systems-level datasets. Nat Commun 10: 1523.

18. Zhang, J. Y., X. M. Wang, X. Xing, Z. Xu, C. Zhang, J. W. Song, X. Fan, P. Xia, J. L. Fu, S. Y. Wang, R. N. Xu, X. P. Dai, L. Shi, L. Huang, T. J. Jiang, M. Shi, Y. Zhang, A. Zumla, M. Maeurer, F. Bai, and F. S. Wang. 2020. Single-cell landscape of immunological responses in patients with COVID-19. Nat Immunol 21: 1107-1118.

19. Davies, J. P., K. M. Almasy, E. F. McDonald, and L. Plate. 2020. Comparative Multiplexed Interactomics of SARS-CoV-2 and Homologous Coronavirus Nonstructural Proteins Identifies Unique and Shared Host-Cell Dependencies. ACS infectious diseases 6: 3174-3189.

20. Klann, K., D. Bojkova, G. Tascher, S. Ciesek, C. Münch, and J. Cinatl. 2020. Growth Factor Receptor Signaling Inhibition Prevents SARS-CoV-2 Replication. Molecular cell 80: 164-174.e164.

21. Sun, J., F. Ye, A. Wu, R. Yang, M. Pan, J. Sheng, W. Zhu, L. Mao, M. Wang, Z. Xia, B. Huang, W. Tan, and T. Jiang. 2020. Comparative Transcriptome Analysis Reveals the Intensive Early Stage Responses of Host Cells to SARS-CoV-2 Infection. Frontiers in microbiology 11: 593857.

22. Bojkova, D., K. Klann, B. Koch, M. Widera, D. Krause, S. Ciesek, J. Cinatl, and C. Münch. 2020. Proteomics of SARS-CoV-2-infected host cells reveals therapy targets. Nature 583: 469-472.

23. Wilk, A. J., A. Rustagi, N. Q. Zhao, J. Roque, G. J. Martínez-Colón, J. L. McKechnie, G. T. Ivison, T. Ranganath, R. Vergara, T. Hollis, L. J. Simpson, P. Grant, A. Subramanian, A. J. Rogers, and C. A. Blish. 2020. A single-cell atlas of the peripheral immune response in patients with severe COVID19. Nature medicine 26: 1070-1076.

24. Lieberman, N. A. P., V. Peddu, H. Xie, L. Shrestha, M. L. Huang, M. C. Mears, M. N. Cajimat, D. A. Bente, P. Y. Shi, F. Bovier, P. Roychoudhury, K. R. Jerome, A. Moscona, M. Porotto, and A. L. Greninger. 2020. In vivo antiviral host transcriptional response to SARS-CoV-2 by viral load, sex, and age. PLoS biology 18: e3000849.

25. Riva, L., S. Yuan, X. Yin, L. Martin-Sancho, N. Matsunaga, L. Pache, S. Burgstaller-Muehlbacher, P. D. De Jesus, P. Teriete, M. V. Hull, M. W. Chang, J. F. Chan, J. Cao, V. K. Poon, K. M. Herbert, K. 
Cheng, T. H. Nguyen, A. Rubanov, Y. Pu, C. Nguyen, A. Choi, R. Rathnasinghe, M. Schotsaert, L. Miorin, M. Dejosez, T. P. Zwaka, K. Y. Sit, L. Martinez-Sobrido, W. C. Liu, K. M. White, M. E. Chapman, E. K. Lendy, R. J. Glynne, R. Albrecht, E. Ruppin, A. D. Mesecar, J. R. Johnson, C. Benner, R. Sun, P. G. Schultz, A. I. Su, A. García-Sastre, A. K. Chatterjee, K. Y. Yuen, and S. K. Chanda. 2020. Discovery of SARS-CoV-2 antiviral drugs through large-scale compound repurposing. Nature 586: 113-119.

26. Bouhaddou, M., D. Memon, B. Meyer, K. M. White, V. V. Rezelj, M. Correa Marrero, B. J. Polacco, J. E. Melnyk, S. Ulferts, R. M. Kaake, J. Batra, A. L. Richards, E. Stevenson, D. E. Gordon, A. Rojc, K. Obernier, J. M. Fabius, M. Soucheray, L. Miorin, E. Moreno, C. Koh, Q. D. Tran, A. Hardy, R. Robinot, T. Vallet, B. E. Nilsson-Payant, C. Hernandez-Armenta, A. Dunham, S. Weigang, J. Knerr, M. Modak, D. Quintero, Y. Zhou, A. Dugourd, A. Valdeolivas, T. Patil, Q. Li, R. Hüttenhain, M. Cakir, M. Muralidharan, M. Kim, G. Jang, B. Tutuncuoglu, J. Hiatt, J. Z. Guo, J. Xu, S. Bouhaddou, C. J. P. Mathy, A. Gaulton, E. J. Manners, E. Félix, Y. Shi, M. Goff, J. K. Lim, T. McBride, M. C. O'Neal, Y. Cai, J. C. J. Chang, D. J. Broadhurst, S. Klippsten, E. De Wit, A. R. Leach, T. Kortemme, B. Shoichet, M. Ott, J. Saez-Rodriguez, B. R. tenOever, R. D. Mullins, E. R. Fischer, G. Kochs, R. Grosse, A. GarcíaSastre, M. Vignuzzi, J. R. Johnson, K. M. Shokat, D. L. Swaney, P. Beltrao, and N. J. Krogan. 2020. The Global Phosphorylation Landscape of SARS-CoV-2 Infection. Cell 182: 685-712.e619.

27. Blanco-Melo, D., B. E. Nilsson-Payant, W. C. Liu, S. Uhl, D. Hoagland, R. Møller, T. X. Jordan, K. Oishi, M. Panis, D. Sachs, T. T. Wang, R. E. Schwartz, J. K. Lim, R. A. Albrecht, and B. R. tenOever. 2020. Imbalanced Host Response to SARS-CoV-2 Drives Development of COVID-19. Cell 181: 10361045.e1039.

28. Shen, B., X. Yi, Y. Sun, X. Bi, J. Du, C. Zhang, S. Quan, F. Zhang, R. Sun, L. Qian, W. Ge, W. Liu, S. Liang, H. Chen, Y. Zhang, J. Li, J. Xu, Z. He, B. Chen, J. Wang, H. Yan, Y. Zheng, D. Wang, J. Zhu, Z. Kong, Z. Kang, X. Liang, X. Ding, G. Ruan, N. Xiang, X. Cai, H. Gao, L. Li, S. Li, Q. Xiao, T. Lu, Y. Zhu, H. Liu, H. Chen, and T. Guo. 2020. Proteomic and Metabolomic Characterization of COVID-19 Patient Sera. Cell 182: 59-72.e15.

29. Lamers, M. M., J. Beumer, J. van der Vaart, K. Knoops, J. Puschhof, T. I. Breugem, R. B. G. Ravelli, J. Paul van Schayck, A. Z. Mykytyn, H. Q. Duimel, E. van Donselaar, S. Riesebosch, H. J. H. Kuijpers, D. Schipper, W. J. van de Wetering, M. de Graaf, M. Koopmans, E. Cuppen, P. J. Peters, B. L. Haagmans, and $\mathrm{H}$. Clevers. 2020. SARS-CoV-2 productively infects human gut enterocytes. Science (New York, N.Y.) 369: 50-54.

30. Gordon, D. E., G. M. Jang, M. Bouhaddou, J. Xu, K. Obernier, K. M. White, M. J. O'Meara, V. V. Rezelj, J. Z. Guo, D. L. Swaney, T. A. Tummino, R. Hüttenhain, R. M. Kaake, A. L. Richards, B. Tutuncuoglu, H. Foussard, J. Batra, K. Haas, M. Modak, M. Kim, P. Haas, B. J. Polacco, H. Braberg, J. M. Fabius, M. Eckhardt, M. Soucheray, M. J. Bennett, M. Cakir, M. J. McGregor, Q. Li, B. Meyer, F. Roesch, T. Vallet, A. Mac Kain, L. Miorin, E. Moreno, Z. Z. C. Naing, Y. Zhou, S. Peng, Y. Shi, Z. Zhang, W. Shen, I. T. Kirby, J. E. Melnyk, J. S. Chorba, K. Lou, S. A. Dai, I. Barrio-Hernandez, D. Memon, C. Hernandez-Armenta, J. Lyu, C. J. P. Mathy, T. Perica, K. B. Pilla, S. J. Ganesan, D. J. Saltzberg, R. Rakesh, X. Liu, S. B. Rosenthal, L. Calviello, S. Venkataramanan, J. Liboy-Lugo, Y. Lin, X. P. Huang, Y. Liu, S. A. Wankowicz, M. Bohn, M. Safari, F. S. Ugur, C. Koh, N. S. Savar, Q. D. Tran, D. Shengjuler, S. J. Fletcher, M. C. O'Neal, Y. Cai, J. C. J. Chang, D. J. Broadhurst, S. Klippsten, P. P. Sharp, N. A. Wenzell, D. Kuzuoglu-Ozturk, H. Y. Wang, R. Trenker, J. M. Young, D. A. Cavero, J. Hiatt, T. L. Roth, U. Rathore, A. Subramanian, J. Noack, M. Hubert, R. M. Stroud, A. D. Frankel, O. S. Rosenberg, K. A. Verba, D. A. Agard, M. Ott, M. Emerman, N. Jura, M. von Zastrow, E. Verdin, A. Ashworth, O. Schwartz, C. d'Enfert, S. Mukherjee, M. Jacobson, H. S. Malik, D. G. Fujimori, T. Ideker, C. S. Craik, S. N. Floor, J. S. Fraser, J. D. Gross, A. Sali, B. L. Roth, D. Ruggero, J. Taunton, T. Kortemme, P. Beltrao, M. Vignuzzi, A. García-Sastre, K. M. Shokat, B. K. Shoichet, and N. J. Krogan. 
2020. A SARS-CoV-2 protein interaction map reveals targets for drug repurposing. Nature 583: 459-468.

31. Xiong, Y., Y. Liu, L. Cao, D. Wang, M. Guo, A. Jiang, D. Guo, W. Hu, J. Yang, Z. Tang, H. Wu, Y. Lin, M. Zhang, Q. Zhang, M. Shi, Y. Liu, Y. Zhou, K. Lan, and Y. Chen. 2020. Transcriptomic characteristics of bronchoalveolar lavage fluid and peripheral blood mononuclear cells in COVID19 patients. Emerging microbes \& infections 9: 761-770.

32. Vanderheiden, A., P. Ralfs, T. Chirkova, A. A. Upadhyay, M. G. Zimmerman, S. Bedoya, H. Aoued, G. M. Tharp, K. L. Pellegrini, C. Manfredi, E. Sorscher, B. Mainou, J. L. Lobby, J. E. Kohlmeier, A. C. Lowen, P. Y. Shi, V. D. Menachery, L. J. Anderson, A. Grakoui, S. E. Bosinger, and M. S. Suthar. 2020. Type I and Type III Interferons Restrict SARS-CoV-2 Infection of Human Airway Epithelial Cultures. Journal of virology 94.

33. Appelberg, S., S. Gupta, S. Svensson Akusjärvi, A. T. Ambikan, F. Mikaeloff, E. Saccon, Á. Végvári, R. Benfeitas, M. Sperk, M. Ståhlberg, S. Krishnan, K. Singh, J. M. Penninger, A. Mirazimi, and U. Neogi. 2020. Dysregulation in Akt/mTOR/HIF-1 signaling identified by proteo-transcriptomics of SARS-CoV-2 infected cells. Emerging microbes \& infections 9: 1748-1760.

34. Stukalov, A., V. Girault, V. Grass, V. Bergant, O. Karayel, C. Urban, D. A. Haas, Y. Huang, L. Oubraham, A. Wang, S. M. Hamad, A. Piras, M. Tanzer, F. M. Hansen, T. Enghleitner, M. Reinecke, T. M. Lavacca, R. Ehmann, R. Wölfel, J. Jores, B. Kuster, U. Protzer, R. Rad, J. Ziebuhr, V. Thiel, P. Scaturro, M. Mann, and A. Pichlmair. 2020. Multi-level proteomics reveals host-perturbation strategies of SARS-CoV-2 and SARS-CoV. bioRxiv : the preprint server for biology: 2020.2006.2017.156455.

35. Emanuel, W., M. Kirstin, F. Vedran, D. Asija, G. L. Theresa, A. Roberto, K. Filippos, K. David, A. Salah, B. Christopher, R. Anja, L. Ivano, I. Andranik, M. Tommaso, D. G. Simone, P. J. Patrick, M. M. Alexander, N. Daniela, S. Matthias, A. Altuna, R. Nikolaus, D. Christian, and L. Markus. 2020. Bulk and single-cell gene expression profiling of SARS-CoV-2 infected human cell lines identifies molecular targets for therapeutic intervention. bioRxiv : the preprint server for biology: 2020.2005.2005.079194.

36. Li, Y., Y. Wang, H. Liu, W. Sun, B. Ding, Y. Zhao, P. Chen, L. Zhu, Z. Li, N. Li, L. Chang, H. Wang, C. Bai, and P. Xu. 2020. Urine Proteome of COVID-19 Patients. medRxiv: 2020.2005.2002.20088666.

37. Liao, M., Y. Liu, J. Yuan, Y. Wen, G. Xu, J. Zhao, L. Cheng, J. Li, X. Wang, F. Wang, L. Liu, I. Amit, S. Zhang, and Z. Zhang. 2020. Single-cell landscape of bronchoalveolar immune cells in patients with COVID-19. Nature medicine 26: 842-844.

38. Bonin, F., S. D. Ryan, L. Migahed, F. Mo, J. Lallier, D. J. Franks, H. Arai, and S. A. Bennett. 2004. Anti-apoptotic actions of the platelet-activating factor acetylhydrolase I alpha2 catalytic subunit. J Biol Chem 279: 52425-52436.

39. Shi, C. S., H. Y. Qi, C. Boularan, N. N. Huang, M. Abu-Asab, J. H. Shelhamer, and J. H. Kehrl. 2014. SARS-coronavirus open reading frame-9b suppresses innate immunity by targeting mitochondria and the MAVS/TRAF3/TRAF6 signalosome. J Immunol 193: 3080-3089.

40. Jiang, H. W., H. N. Zhang, Q. F. Meng, J. Xie, Y. Li, H. Chen, Y. X. Zheng, X. N. Wang, H. Qi, J. Zhang, P. H. Wang, Z. G. Han, and S. C. Tao. 2020. SARS-CoV-2 Orf9b suppresses type I interferon responses by targeting TOM70. Cellular \& molecular immunology 17: 998-1000.

41. Gibellini, L., S. De Biasi, A. Paolini, R. Borella, F. Boraldi, M. Mattioli, D. Lo Tartaro, L. Fidanza, A. Caro-Maldonado, M. Meschiari, V. Iadisernia, E. Bacca, G. Riva, L. Cicchetti, D. Quaglino, G. Guaraldi, S. Busani, M. Girardis, C. Mussini, and A. Cossarizza. 2020. Altered bioenergetics and mitochondrial dysfunction of monocytes in patients with COVID-19 pneumonia. EMBO molecular medicine 12: e13001. 
42. Loke, P., S. N. Hammond, J. M. Leung, C. C. Kim, S. Batra, C. Rocha, A. Balmaseda, and E. Harris. 2010. Gene expression patterns of dengue virus-infected children from nicaragua reveal a distinct signature of increased metabolism. PLoS neglected tropical diseases 4: e710.

43. Karniely, S., M. P. Weekes, R. Antrobus, J. Rorbach, L. van Haute, Y. Umrania, D. L. Smith, R. J. Stanton, M. Minczuk, P. J. Lehner, and J. H. Sinclair. 2016. Human Cytomegalovirus Infection Upregulates the Mitochondrial Transcription and Translation Machineries. mBio 7: e00029.

44. Báez-Santos, Y. M., A. M. Mielech, X. Deng, S. Baker, and A. D. Mesecar. 2014. Catalytic function and substrate specificity of the papain-like protease domain of nsp3 from the Middle East respiratory syndrome coronavirus. Journal of virology 88: 12511-12527.

45. Freitas, B. T., I. A. Durie, J. Murray, J. E. Longo, H. C. Miller, D. Crich, R. J. Hogan, R. A. Tripp, and S. D. Pegan. 2020. Characterization and Noncovalent Inhibition of the Deubiquitinase and delSGylase Activity of SARS-CoV-2 Papain-Like Protease. ACS infectious diseases 6: 2099-2109.

46. Shi, S. T., G. Y. Yu, and M. M. Lai. 2003. Multiple type A/B heterogeneous nuclear ribonucleoproteins (hnRNPs) can replace hnRNP A1 in mouse hepatitis virus RNA synthesis. Journal of virology 77: 10584-10593.

47. Watkin, L. B., B. Jessen, W. Wiszniewski, T. J. Vece, M. Jan, Y. Sha, M. Thamsen, R. L. Santos-Cortez, K. Lee, T. Gambin, L. R. Forbes, C. S. Law, A. Stray-Pedersen, M. H. Cheng, E. M. Mace, M. S. Anderson, D. Liu, L. F. Tang, S. K. Nicholas, K. Nahmod, G. Makedonas, D. L. Canter, P. Y. Kwok, J. Hicks, K. D. Jones, S. Penney, S. N. Jhangiani, M. D. Rosenblum, S. D. Dell, M. R. Waterfield, F. R. Papa, D. M. Muzny, N. Zaitlen, S. M. Leal, C. Gonzaga-Jauregui, E. Boerwinkle, N. T. Eissa, R. A. Gibbs, J. R. Lupski, J. S. Orange, and A. K. Shum. 2015. COPA mutations impair ER-Golgi transport and cause hereditary autoimmune-mediated lung disease and arthritis. Nat Genet 47: 654-660.

48. Dieker, J., B. Cisterna, F. Monneaux, M. Decossas, J. van der Vlag, M. Biggiogera, and S. Muller. 2008. Apoptosis-linked changes in the phosphorylation status and subcellular localization of the spliceosomal autoantigen U1-70K. Cell Death Differ 15: 793-804.

49. Utz, P. J., M. Hottelet, W. J. van Venrooij, and P. Anderson. 1998. Association of phosphorylated serine/arginine (SR) splicing factors with the U1-small ribonucleoprotein (snRNP) autoantigen complex accompanies apoptotic cell death. J Exp Med 187: 547-560.

50. Pfeifle, J., F. A. Anderer, and M. Franke. 1987. Multiple phosphorylation of human SS-B/LA autoantigen and its effect on poly(U) and autoantibody binding. Biochim Biophys Acta 928: 217226.

51. Rutjes, S. A., P. J. Utz, A. van der Heijden, C. Broekhuis, W. J. van Venrooij, and G. J. Pruijn. 1999. The La (SS-B) autoantigen, a key protein in RNA biogenesis, is dephosphorylated and cleaved early during apoptosis. Cell Death Differ 6: 976-986.

52. Zampieri, S., W. Degen, A. Ghiradello, A. Doria, and W. J. van Venrooij. 2001. Dephosphorylation of autoantigenic ribosomal $P$ proteins during Fas-L induced apoptosis: a possible trigger for the development of the autoimmune response in patients with systemic lupus erythematosus. Ann Rheum Dis 60: 72-76.

53. Ge, S. X., D. Jung, and R. Yao. 2020. ShinyGO: a graphical gene-set enrichment tool for animals and plants. Bioinformatics (Oxford, England) 36: 2628-2629. 
bioRxiv preprint doi: https://doi.org/10.1101/2021.02.21.432171; this version posted February 22, 2021. The copyright holder for this preprint (which was not certified by peer review) is the author/funder, who has granted bioRxiv a license to display the preprint in perpetuity. It is made available under aCC-BY 4.0 International license.

\section{Table 1. DS-affinity autoantigenome from human A549 cells}

\begin{tabular}{|c|c|c|c|c|c|c|c|c|c|c|}
\hline \multirow{2}{*}{$\begin{array}{c}\# \\
\text { Pep. }\end{array}$} & \multirow{2}{*}{ Gene } & \multirow{2}{*}{ Protein } & \multicolumn{2}{|c|}{ COVID } & \multicolumn{2}{|c|}{$\begin{array}{c}\text { A549 } \\
\text { infection }\end{array}$} & \multirow{2}{*}{$\begin{array}{l}\text { Inter- } \\
\text { actome }\end{array}$} & \multicolumn{2}{|c|}{$\begin{array}{l}\text { DS- } \\
\text { affinity }\end{array}$} & \multirow{2}{*}{$\begin{array}{l}\text { AutoAd } \\
\text { ref. }\end{array}$} \\
\hline & & & up & down & up & down & & $\begin{array}{l}1.0 \\
M\end{array}$ & $\begin{array}{c}0.5 \\
\mathrm{M}\end{array}$ & \\
\hline 2 & A2M & Alpha-2-macroglobulin & & D & & & & & + & (1) \\
\hline 2 & ACLY & ATP-citrate synthase & $\mathrm{U}$ & D & $\mathrm{U}$ & D & & & + & (2) \\
\hline 9 & ACTA2 & Actin, aortic smooth muscle & $\mathrm{U}$ & $\mathrm{D}$ & $\mathrm{U}$ & D & & + & & (3) \\
\hline 8 & ACTB & Actin, cytoplasmic 1 & $\mathrm{U}$ & $\mathrm{D}$ & $\mathrm{U}$ & D & & + & & (4) \\
\hline 5 & ACTBL2 & Beta-actin-like protein 2 & U & $\mathrm{D}$ & $\mathrm{U}$ & $\mathrm{D}$ & & + & & (4) \\
\hline 20 & ACTN1 & Alpha-actinin-1 & $\mathrm{U}$ & $\mathrm{D}$ & $\mathrm{U}$ & D & & & + & (5) \\
\hline 20 & ACTN4 & Alpha-actinin-4 & $\mathrm{U}$ & D & $\mathrm{U}$ & & & & + & (3) \\
\hline 2 & ADSS2 & Adenylosuccinate synthetase isozyme 2 & $\mathrm{U}$ & & $\mathrm{U}$ & & & & + & \\
\hline 3 & AFP & Alpha-fetoprotein & & D & & & & & + & (6) \\
\hline 2 & AGRN & Agrin & $\mathrm{U}$ & & $\mathrm{U}$ & & & + & & (7) \\
\hline 6 & $\mathrm{AHCY}$ & Adenosylhomocysteinase & & D & & D & & & + & \\
\hline 5 & AKR1B1 & Aldose reductase (diabetic complication) & $\mathrm{U}$ & $\mathrm{D}$ & $\mathrm{U}$ & $\mathrm{D}$ & Orf3 & & + & (8) \\
\hline 6 & ALB & Putative uncharacterized protein ALB & $\mathrm{U}$ & $\mathrm{D}$ & U & D & & + & & (9) \\
\hline 23 & ALDH1A1 & Retinal dehydrogenase & $\mathrm{U}$ & D & $\mathrm{U}$ & D & & & + & (10) \\
\hline 5 & ALDH2 & Aldehyde dehydrogenase, mitochondrial & $\mathrm{U}$ & $\mathrm{D}$ & & & & & + & (11) \\
\hline 5 & ALDH3A1 & Aldehyde dehydrogenase, dimeric NADP-preferring, ALDH3 & $\mathrm{U}$ & D & $\mathrm{U}$ & D & & & + & \\
\hline 9 & ALDOA & Fructose-bisphosphate aldolase & $\mathrm{U}$ & $\mathrm{D}$ & $\mathrm{U}$ & $\mathrm{D}$ & & & + & (12) \\
\hline 6 & ANP32A & Acidic leucine-rich nuclear phosphoprotein 32 family member $A$ & $\mathrm{U}$ & $\mathrm{D}$ & & D & & + & & \\
\hline 13 & ANP32B & $\begin{array}{l}\text { Acidic leucine-rich nuclear phosphoprotein } 32 \text { family member B, } \\
\text { APRIL }\end{array}$ & & D & & $\mathrm{D}$ & & + & & (13) \\
\hline 3 & ANP32C & $\begin{array}{l}\text { Acidic leucine-rich nuclear phosphoprotein } 32 \text { family member C, } \\
\text { PP32R1 }\end{array}$ & & & & & & + & & \\
\hline 4 & ANP32E & Acidic leucine-rich nuclear phosphoprotein 32 family member $E$ & $\mathrm{U}$ & D & $\mathrm{U}$ & D & & + & & \\
\hline 4 & ANXA2 & Annexin A2 & $\mathrm{U}$ & $\mathrm{D}$ & $\mathrm{U}$ & & & & + & (14) \\
\hline 13 & ANXA2P2 & Annexin A2 pseudogene 2 & $\mathrm{U}$ & D & $\mathrm{U}$ & & & & + & (14) \\
\hline 10 & ANXA3 & Annexin A3 & $\mathrm{U}$ & $\mathrm{D}$ & $\mathrm{U}$ & & & & + & (15) \\
\hline 5 & ANXA4 & Annexin IV & $\mathrm{U}$ & $\mathrm{D}$ & $\mathrm{U}$ & D & & & + & (16) \\
\hline 15 & ANXA5 & Annexin A5 & $\mathrm{U}$ & D & $\mathrm{U}$ & $\mathrm{D}$ & Orf3 & & + & (17) \\
\hline 8 & ANXA6 & Annexin VI & $\mathrm{U}$ & $\mathrm{D}$ & & & & & + & (18) \\
\hline 8 & AP3B1 & AP-3 complex subunit beta- 1 & $\mathrm{U}$ & & & & $\mathrm{E}$ & + & & \\
\hline 2 & AP3B2 & AP-3 complex subunit beta-2 & & & & & & + & & (19) \\
\hline 8 & AP3D1 & AP- 3 complex subunit delta- 1 & $\mathrm{U}$ & D & & & & + & & \\
\hline 4 & APEX1 & DNA-(apurinic or apyrimidinic site) endonuclease & $\mathrm{U}$ & D & $\mathrm{U}$ & D & & & + & (20) \\
\hline 4 & $\mathrm{ASPH}$ & Aspartyl/asparaginyl beta-hydroxylase & $\mathrm{U}$ & $\mathrm{D}$ & & $\mathrm{D}$ & & + & & \\
\hline 2 & ATP2A2 & $\begin{array}{l}\text { ATP Sarcoplasmic/ER calcium transporting } 2 \text { (cardiac Ca2+ ATPase, } \\
\text { heart failure) }\end{array}$ & $\mathrm{U}$ & & & & Nsp4 & + & & (21) \\
\hline 13 & ATP5B & ATP synthase subunit beta, mitochondrial, ATP5F1B & U & $\mathrm{D}$ & & & Nsp6 & + & & (22) \\
\hline 3 & BRIX1 & Ribosome biogenesis protein BRX1 homolog & & & & & & + & & \\
\hline 8 & C1QBP & Complement C1q-binding protein, mitochondrial matrix protein $\mathrm{p} 32$ & & D & & D & & + & & (23) \\
\hline 10 & CALR & Calreticulin & $\mathrm{U}$ & D & $\mathrm{U}$ & & & & + & (24) \\
\hline 7 & CANX & Calnexin & $\mathrm{U}$ & D & $\mathrm{U}$ & D & Nsp4 & + & & (25) \\
\hline 2 & CAP1 & Cyclase associated actin cytoskeleton regulatory protein 1 & $\mathrm{U}$ & $\mathrm{D}$ & & & Orf3 & & + & \\
\hline 2 & CAPN1 & Calpain-1 catalytic subunit & & & & & & & + & \\
\hline 2 & CAPZB & F-actin-capping protein subunit beta & & $\mathrm{D}$ & & & & & + & (26) \\
\hline 5 & ССТ8 & T-complex protein 1 subunit theta & $\mathrm{U}$ & $\mathrm{D}$ & $\mathrm{U}$ & D & & & + & (27) \\
\hline 3 & CDK11A & Cyclin-dependent kinase 11A, CDC2L2 & $\mathrm{U}$ & & & & & + & & \\
\hline 3 & CEBPZ & CCAAT/enhancer-binding protein zeta & $\mathrm{U}$ & & & & & + & & \\
\hline 4 & CLIC1 & Chloride intracellular channel protein 1 & $\mathrm{U}$ & D & & & & & + & (28) \\
\hline 4 & CLTC & Clathrin heavy chain 1 & $\mathrm{U}$ & $\mathrm{D}$ & & D & & + & & (29) \\
\hline 2 & CLTCL1 & Clathrin heavy chain 2 & & & & & & + & & \\
\hline 2 & COPA & Coatomer subunit alpha & $\mathrm{U}$ & D & $\mathrm{U}$ & D & & + & & (30) \\
\hline 2 & CPNE3 & Copine-3 & $\mathrm{U}$ & $\mathrm{D}$ & & & & & + & \\
\hline 2 & CTR9 & RNA polymerase-associated protein CTR9 homolog & $\mathrm{U}$ & D & & D & & + & & \\
\hline 4 & DCAF1 & DDB1- and CUL4-associated factor 1, VPRBP & $\mathrm{U}$ & D & $\mathrm{U}$ & & & + & & \\
\hline 13 & DDB1 & DNA damage-binding protein 1 & U & $\mathrm{D}$ & U & D & & + & & (29) \\
\hline 3 & DDX17 & Probable ATP-dependent RNA helicase DDX17 & $\mathrm{U}$ & $\mathrm{D}$ & $\mathrm{U}$ & & & + & & \\
\hline 7 & DDX18 & ATP-dependent RNA helicase DDX18 & $\mathrm{U}$ & & & & & + & & \\
\hline 5 & DDX21 & Nucleolar RNA helicase 2 (RH II/Gu) & $\mathrm{U}$ & $\mathrm{U}$ & & & $\mathrm{N}$ & + & & (31) \\
\hline 4 & DDX27 & Probable ATP-dependent RNA helicase DDX27 & U & & $\mathrm{U}$ & & & + & & \\
\hline 3 & DDX30 & ATP-dependent RNA helicase DHX30, DDX30 & & & & & & + & & \\
\hline 8 & DDX48 & Eukaryotic initiation factor 4A-III, EIF4A3 & & & & & & + & & \\
\hline 4 & DDX5 & Probable ATP-dependent RNA helicase DDX5 & $\mathrm{U}$ & D & & & & + & & \\
\hline 16 & DDX9 & ATP-dependent RNA helicase A, DHX9 & & & & & & + & & (32) \\
\hline 12 & DHX15 & $\begin{array}{l}\text { Putative pre-mRNA-splicing factor ATP-dependent RNA helicase } \\
\text { DHX15 }\end{array}$ & & D & & & & + & & \\
\hline 4 & DHX36 & Probable ATP-dependent RNA helicase DHX36 & $\mathrm{U}$ & & & & & + & & \\
\hline 4 & DKC1 & H/ACA ribonucleoprotein complex subunit B & $\mathrm{U}$ & D & & $\mathrm{D}$ & & + & & \\
\hline 3 & DPP3 & Dipeptidyl-peptidase 3 & & $\mathrm{D}$ & & & & & + & \\
\hline 3 & DYNC112 & Cytoplasmic dynein 1 intermediate chain 2 & & & & & & + & & \\
\hline
\end{tabular}


bioRxiv preprint doi: https://doi.org/10.1101/2021.02.21.432171; this version posted February 22, 2021. The copyright holder for this preprint (which was not certified by peer review) is the author/funder, who has granted bioRxiv a license to display the preprint in perpetuity. It is made available under aCC-BY 4.0 International license.

\begin{tabular}{|c|c|c|c|c|c|c|c|c|c|c|}
\hline 3 & EBP2 & Probable rRNA-processing protein, EBNA1BP2 & & & & & & + & & \\
\hline 4 & $\mathrm{ECH} 1$ & Delta(3,5)-Delta(2,4)-dienoyl-CoA isomerase, mitochondrial & $\mathrm{U}$ & $\mathrm{D}$ & $\mathrm{U}$ & & & & + & (33) \\
\hline 2 & EEF1A1 & Elongation factor 1 -alpha 1 & $\mathrm{U}$ & $\mathrm{D}$ & $\mathrm{U}$ & D & & & + & (34) \\
\hline 2 & EEF1A2 & Elongation factor 1 -alpha 2 & $\mathrm{U}$ & & U & & Orf3 & + & & (35) \\
\hline 2 & EEF1G & Elongation factor 1-gamma & $\mathrm{U}$ & $\mathrm{D}$ & $\mathrm{U}$ & & & & + & \\
\hline 3 & EEF2 & Elongation factor 2 & $\mathrm{U}$ & D & U & & & + & & (36) \\
\hline 16 & EFTUD2 & $116 \mathrm{kDa}$ U5 small nuclear ribonucleoprotein component & & D & & D & & + & & (37) \\
\hline 2 & EIF2A & Eukaryotic translation initiation factor 2 subunit 1 , EIF2 & & & & & & & + & \\
\hline 6 & EIF3A & Eukaryotic translation initiation factor 3 subunit $\mathrm{A}$ & $\mathrm{U}$ & D & & D & & + & & (38) \\
\hline 4 & EIF3B & Eukaryotic translation initiation factor 3 subunit & $\mathrm{U}$ & $\mathrm{D}$ & & D & & + & & \\
\hline 3 & EIF3CL & Eukaryotic translation initiation factor 3 subunit C-like protein & & $\mathrm{D}$ & & D & & + & & \\
\hline 2 & EIF3E & Eukaryotic translation initiation factor 3 subunit $\mathrm{E}$ & $\mathrm{U}$ & $\mathrm{D}$ & $\mathrm{U}$ & & & + & & (39) \\
\hline 7 & EIF3L & Eukaryotic translation initiation factor 3 , subunit $E$ interacting protein & & $\mathrm{D}$ & & & & + & & \\
\hline 13 & EIF4A1 & Eukaryotic initiation factor $4 \mathrm{~A}-\mathrm{I}, \mathrm{DDX} 2 \mathrm{~A}$ & $\mathrm{U}$ & $\mathrm{D}$ & $\mathrm{U}$ & $\mathrm{D}$ & & & + & \\
\hline 2 & EIF5A & Eukaryotic translation initiation factor $5 \mathrm{~A}-1$ & $\mathrm{U}$ & $\mathrm{D}$ & $\mathrm{U}$ & D & & & + & $(40)$ \\
\hline 2 & EMG1 & Ribosomal RNA small subunit methyltransferase NEP1 & U & D & & & & & + & \\
\hline 3 & ENO1 & Isoform alpha-enolase of Alpha-enolase & $\mathrm{U}$ & $\mathrm{D}$ & $\mathrm{U}$ & D & & & + & (41) \\
\hline 6 & EPHX1 & Epoxide hydrolase & & D & & D & & + & & (42) \\
\hline 3 & ESYT1 & Extended synaptotagmin-1 & & & & & & + & & (43) \\
\hline 3 & EZR & Ezrin & $\mathrm{U}$ & D & $\mathrm{U}$ & D & & & + & (44) \\
\hline 3 & FKBP4 & FK506-binding protein, FKBP52 & & & & & & & + & (45) \\
\hline 27 & FLNA & Filamin-A & $\mathrm{U}$ & D & $\mathrm{U}$ & D & & + & & (46) \\
\hline 25 & FLNB & Filamin-B & $\mathrm{U}$ & & $\mathrm{U}$ & & & & + & (29) \\
\hline 9 & FLNC & Filamin-C & $\mathrm{U}$ & D & & & & + & & (47) \\
\hline 2 & FTH1 & Ferritin heavy chain & $\mathrm{U}$ & D & $\mathrm{U}$ & D & & & + & $(48)$ \\
\hline 10 & G6PD & Glucose-6-phosphate 1-dehydrogenase (anemia, diabetes) & U & $\mathrm{D}$ & $\mathrm{U}$ & & & + & & (49) \\
\hline 5 & GANAB & Neutral alpha-glucosidase A & & $\mathrm{D}$ & & D & & & + & $(50)$ \\
\hline 2 & GAPDH & Glyceraldehyde-3-phosphate dehydrogenase & $\mathrm{U}$ & $\mathrm{D}$ & & D & & & + & (51) \\
\hline 2 & GAR1 & H/ACA ribonucleoprotein complex subunit 1 & & & & & & + & & \\
\hline 2 & GBE1 & 1,4-alpha-glucan-branching enzyme & $\mathrm{U}$ & & & & & & + & \\
\hline 4 & GCLC & Glutamate-cysteine ligase catalytic subunit (hemolytic anemia) & & & & & Orf3 & & + & \\
\hline 6 & GDI1 & Rab GDP dissociation inhibitor alpha & $\mathrm{U}$ & $\mathrm{D}$ & $\mathrm{U}$ & & & & + & (52) \\
\hline 7 & GDI2 & cDNA FLJ60299, highly similar to Rab GDP dissociation inhibitor beta & $\mathrm{U}$ & $\mathrm{D}$ & $\mathrm{U}$ & & & & + & $(53)$ \\
\hline 2 & GLO1 & Lactoylglutathione lyase (prostasome) & & D & & & Orf3 & & + & (54) \\
\hline 2 & GPC1 & Glypican-1 & & $\mathrm{D}$ & & D & & + & & \\
\hline 2 & GPI & Glucose-6-phosphate isomerase & $\mathrm{U}$ & D & $\mathrm{U}$ & D & Orf3 & & + & (55) \\
\hline 4 & GRWD1 & Glutamate-rich WD repeat-containing protein 1 & & & & & & + & & \\
\hline 6 & GSTP1 & Glutathione S-transferase & $\mathrm{U}$ & $\mathrm{D}$ & & D & & & + & $(56)$ \\
\hline 2 & H2AFR & Histone H2A type 1-A, H2AC1, HIST1H2AA & & & & & & + & & (57) \\
\hline 3 & H2AFV & Histone H2A.V, H2AZ2 & & $\mathrm{D}$ & & D & & + & & (57) \\
\hline 11 & H2AFY & H2A histone family, member $\mathrm{Y}$ isoform, MacroH2A1 & $\mathrm{U}$ & & & & & + & & (58) \\
\hline 2 & H2AFY2 & Core histone macro-H2A.2, MACROH2A2 & & & & & & + & & (57) \\
\hline 4 & HADHA & Trifunctional enzyme subunit alpha, mitochondrial & & & & & & + & & \\
\hline 2 & HARS & Histidyl-tRNA synthetase, cytoplasmic, HRS & & & & & & & + & (59) \\
\hline 4 & HEATR1 & HEAT repeat-containing protein 1 & $\mathrm{U}$ & $\mathrm{D}$ & $\mathrm{U}$ & D & & + & & \\
\hline 2 & HIST1H1B & Histone $\mathrm{H} 1.5, \mathrm{H} 1-5$ & $\mathrm{U}$ & $\mathrm{D}$ & & $\mathrm{D}$ & & + & & $(60)$ \\
\hline 6 & HIST1H1C & Histone $\mathrm{H} 1.2$ & $\mathrm{U}$ & $\mathrm{D}$ & $\mathrm{U}$ & $\mathrm{D}$ & & + & & $(60)$ \\
\hline 2 & HIST1H2BL & Histone H2B type 1-L, H2BC13 & $\mathrm{U}$ & D & $\mathrm{U}$ & D & & + & & (61) \\
\hline 9 & HIST1H4J & Histone $\mathrm{H} 4, \mathrm{H} 4 \mathrm{C} 1$ & $\mathrm{U}$ & $\mathrm{D}$ & $\mathrm{U}$ & D & & + & & (62) \\
\hline 12 & HIST2H2BE & Histone H2B type 2-E, H2BC21 & U & D & & D & & + & & (63) \\
\hline 5 & HIST2H3A & HIST2H3C, Histone H3.2, H3C15 & U & $\mathrm{D}$ & U & & & + & & (64) \\
\hline 3 & $\begin{array}{l}\text { HNRNPA2B } \\
1\end{array}$ & Heterogenous nuclear ribonucleoproteins A2/B1 & $\mathrm{U}$ & $\mathrm{D}$ & & & & & + & $(65)$ \\
\hline 3 & HNRNPC & Heterogeneous nuclear ribonucleoproteins C1/C2 & $U$ & $\mathrm{D}$ & U & D & & + & & $(66)$ \\
\hline 6 & HNRNPCL1 & Heterogeneous nuclear ribonucleoprotein C-like 1 & & & & & & + & & \\
\hline 4 & HNRNPF & Heterogeneous nuclear ribonucleoprotein $\mathrm{F}$ & & $\mathrm{D}$ & & D & & + & & $(67)$ \\
\hline 2 & HNRNPH1 & Heterogeneous nuclear ribonucleoprotein $\mathrm{H}$ & $\mathrm{U}$ & D & $\mathrm{U}$ & & & + & & $(67)$ \\
\hline 3 & HNRNPK & Heterogeneous nuclear ribonucleoprotein $\mathrm{K}$ & $\mathrm{U}$ & & & & & & + & (68) \\
\hline 3 & HNRNPM & Heterogeneous nuclear ribonucleoprotein M & $\mathrm{U}$ & $\mathrm{D}$ & & D & & + & & \\
\hline 4 & HNRNPR & Heterogeneous nuclear ribonucleoprotein $\mathrm{R}$ & $\mathrm{U}$ & D & $\mathrm{U}$ & & & & + & (69) \\
\hline 2 & HNRNPU & Heterogeneous nuclear ribonucleoprotein U & U & D & U & D & & + & & \\
\hline 6 & HNRNPUL1 & hnRNP U-like protein 1 & $\mathrm{U}$ & $\mathrm{D}$ & & $\mathrm{D}$ & & + & & \\
\hline 4 & HNRNPUL2 & hnRNP U-like protein 2 & $\mathrm{U}$ & $\mathrm{D}$ & & & & + & & \\
\hline 4 & HSP70T & Heat shock $70 \mathrm{kDa}$ protein 1 -like, HSPA1L & & & & & & & + & \\
\hline 11 & HSP90AA1 & Heat shock $90 \mathrm{kDa}$ protein 1 , alpha isoform & $\mathrm{U}$ & $\mathrm{D}$ & $\mathrm{U}$ & & & & + & (70) \\
\hline 3 & HSP90AA2 & Heat shock protein HSP 90-alpha A2 & $\mathrm{U}$ & $\mathrm{D}$ & u & & & + & & $(71)$ \\
\hline 5 & HSP90AB1 & Heat shock protein HSP 90-beta & $\mathrm{U}$ & $\mathrm{D}$ & $\mathrm{U}$ & & & & + & (72) \\
\hline 23 & HSP90B1 & Endoplasmin & U & $\mathrm{D}$ & $\mathrm{U}$ & & & + & & (73) \\
\hline 7 & HSPA1A & Heat shock $70 \mathrm{kDa}$ protein $1 \mathrm{~A}$ & $\mathrm{U}$ & D & $\mathrm{U}$ & D & $\begin{array}{c}N \\
\text { Orf9b }\end{array}$ & & + & (74) \\
\hline 35 & HSPA5 & HSPA5 protein, BiP, GRP78 & U & $\mathrm{D}$ & $U$ & D & $\begin{array}{l}\text { Nsp2 } \\
\text { Nsp4 }\end{array}$ & + & & $(75)$ \\
\hline 2 & HSP70B & Putative heat shock $70 \mathrm{kDa}$ protein, HSPA7 & U & $\mathrm{D}$ & U & & & + & & \\
\hline 20 & HSPA8 & Heat shock cognate $71 \mathrm{kDa}$ protein & U & $\mathrm{D}$ & U & & Nsp2 & + & & $(76)$ \\
\hline 17 & HSPA9 & Stress-70 protein, mitochondrial & $\mathrm{U}$ & $\mathrm{D}$ & & $\mathrm{D}$ & $\mathrm{N}$ & & + & (76) \\
\hline
\end{tabular}


bioRxiv preprint doi: https://doi.org/10.1101/2021.02.21.432171; this version posted February 22, 2021. The copyright holder for this preprint (which was not certified by peer review) is the author/funder, who has granted bioRxiv a license to display the preprint in perpetuity. It is made available under aCC-BY 4.0 International license.

\begin{tabular}{|c|c|c|c|c|c|c|c|c|c|c|}
\hline 2 & HSPBP1 & Hsp70-binding protein & U & $\mathrm{D}$ & & & & & + & (77) \\
\hline 3 & HSPG2 & $\begin{array}{l}\text { Basement membrane-specific heparan sulfate proteoglycan core } \\
\text { protein }\end{array}$ & $U$ & $\mathrm{D}$ & $U$ & & & + & & $(78)$ \\
\hline 4 & HTATSF1 & HIV Tat-specific factor 1 & & $\mathrm{D}$ & & $\mathrm{D}$ & & + & & \\
\hline 4 & IDE & Insulin-degrading enzyme (insulin, amyloid) & & & & & Nsp4 & & + & \\
\hline 2 & IL18 & Interleukin-18 & $\mathrm{U}$ & D & $\mathrm{U}$ & $\mathrm{D}$ & & & + & (79) \\
\hline 5 & ILF2 & Interleukin enhancer-binding factor & $\mathrm{U}$ & & $\mathrm{U}$ & & & + & & $(80)$ \\
\hline 9 & IQGAP1 & Ras GTPase-activating-like protein IQGAP1 & $\mathrm{U}$ & & & & & + & & $(81)$ \\
\hline 4 & ITGB1 & Integrin beta- 1 & $U$ & $\mathrm{D}$ & & D & $\begin{array}{l}\text { Nsp4 } \\
\text { Orf8 }\end{array}$ & + & & $(82)$ \\
\hline 2 & IWS1 & Protein IWS1 homolog & U & $\mathrm{D}$ & U & $\mathrm{D}$ & & + & & \\
\hline 3 & KARS & Lysyl-tRNA synthetase & & & & & & + & & $(83)$ \\
\hline 10 & KPNB1 & Importin subunit beta-1, IPOB, & & & & & & + & & (84) \\
\hline 2 & KRR1 & $\begin{array}{l}\text { KRR1 small subunit processome component homolog, HIV-1 Rev- } \\
\text { binding protein }\end{array}$ & & & & & & + & & $(85)$ \\
\hline 2 & KYNU & Kynureninase & $\mathrm{U}$ & & $\mathrm{U}$ & & Orf3 & & + & \\
\hline 2 & LAMP2 & Lysosome-associated membrane glycoprotein 2 & U & D & U & D & & & + & $(86)$ \\
\hline 2 & LARS & Leucyl-tRNA synthetase, cytoplasmic & & & & & & + & & (83) \\
\hline 3 & LCP1 & Plastin-2 & $\mathrm{U}$ & $\mathrm{D}$ & & & & & + & $(87)$ \\
\hline 8 & LDHA & L-lactate dehydrogenase & $\mathrm{U}$ & D & $\mathrm{U}$ & $\mathrm{D}$ & & & + & $(88)$ \\
\hline 9 & LDHB & L-lactate dehydrogenase $B$ chain & $\mathrm{U}$ & $\mathrm{D}$ & $\mathrm{U}$ & $\mathrm{D}$ & & & + & $(88)$ \\
\hline 2 & LEO1 & RNA polymerase-associated protein LEO1 & $\mathrm{U}$ & & $\mathrm{U}$ & & & + & & \\
\hline 6 & LMNA & Lamin-A/C & $\mathrm{U}$ & $\mathrm{D}$ & $\mathrm{U}$ & $\mathrm{D}$ & & & + & $(89)$ \\
\hline 2 & LMNB2 & Lamin-B & $\mathrm{U}$ & $\mathrm{D}$ & & & & + & & (90) \\
\hline 4 & LRPPRC & Leucine-rich PPR motif-containing protein, mitochondrial & & $\mathrm{D}$ & & & & & + & (91) \\
\hline 3 & MAP1B & Microtubule-associated protein 1B & $\mathrm{U}$ & $\mathrm{D}$ & $\mathrm{U}$ & $\mathrm{D}$ & & + & & (92) \\
\hline 2 & MARS & Methionyl-tRNA synthetase, cytoplasmic, SLA2 & & $\mathrm{D}$ & & $\mathrm{D}$ & & + & & \\
\hline 3 & $\mathrm{MDH} 2$ & Malate dehydrogenase, mitochondrial & $\mathrm{U}$ & $\mathrm{D}$ & & & & & + & (93) \\
\hline 4 & MOV10 & Helicase MOV-10, Moloney Leukemia virus 10 protein & $\mathrm{U}$ & $\mathrm{D}$ & & $\mathrm{D}$ & $\mathrm{N}$ & + & & \\
\hline 5 & MRPL1 & 39S ribosomal protein $\mathrm{L} 1$, mitochondrial & & & & & & + & & \\
\hline 3 & MRPL13 & 39 S ribosomal protein $\mathrm{L} 13$, mitochondrial & & D & & D & & + & & \\
\hline 2 & MRPL15 & $39 S$ ribosomal protein $\mathrm{L} 15$, mitochondrial & $\mathrm{U}$ & $\mathrm{D}$ & & $\mathrm{D}$ & & + & & \\
\hline 2 & MRPL17 & $39 S$ ribosomal protein L17, mitochondrial & & $\mathrm{D}$ & & $\mathrm{D}$ & & + & & \\
\hline 2 & MRPL18 & $39 S$ ribosomal protein $L 18$, mitochondrial & & $\mathrm{D}$ & & $\mathrm{D}$ & & + & & \\
\hline 4 & MRPL19 & 39S ribosomal protein L19, mitochondrial & & $\mathrm{D}$ & & $\mathrm{D}$ & & + & & \\
\hline 2 & MRPL2 & 39 S ribosomal protein $\mathrm{L} 2$, mitochondrial & & $\mathrm{D}$ & & $\mathrm{D}$ & & + & & \\
\hline 2 & MRPL23 & $39 \mathrm{~S}$ ribosomal protein $\mathrm{L} 23$, mitochondrial & & $\mathrm{D}$ & & & & + & & \\
\hline 5 & MRPL37 & $39 S$ ribosomal protein L37, mitochondrial & $\mathrm{U}$ & $\mathrm{D}$ & & $\mathrm{D}$ & & + & & \\
\hline 5 & MRPL38 & 39 S ribosomal protein L38, mitochondrial & & $\mathrm{D}$ & & D & & + & & \\
\hline 2 & MRPL39 & $39 S$ ribosomal protein L39, mitochondrial & & $\mathrm{D}$ & & $\mathrm{D}$ & & + & & \\
\hline 3 & MRPL45 & $39 S$ ribosomal protein $L 45$, mitochondrial & & $\mathrm{D}$ & & D & & + & & \\
\hline 2 & MRPL49 & $39 S$ ribosomal protein $L 49$, mitochondrial & & $\mathrm{D}$ & & D & & + & & \\
\hline 4 & MRPS22 & $28 \mathrm{~S}$ ribosomal protein $\mathrm{S} 22$, mitochondrial & & & & & & + & & \\
\hline 4 & MRPS23 & $28 \mathrm{~S}$ ribosomal protein $\mathrm{S} 23$, mitochondrial & & & & & & + & & \\
\hline 6 & MRPS27 & $28 \mathrm{~S}$ ribosomal protein $\mathrm{S} 27$, mitochondrial & & & & & Nsp8 & + & & \\
\hline 2 & MRPS28 & $28 \mathrm{~S}$ ribosomal protein S28, mitochondrial, MRPS35 & & & & & & + & & \\
\hline 6 & MRPS29 & $28 \mathrm{~S}$ ribosomal protein S29, mitochondrial, DAP3 & & & & & & + & & \\
\hline 2 & MRPS30 & $28 \mathrm{~S}$ ribosomal protein $\mathrm{S} 30$, mitochondrial & & D & & $\mathrm{D}$ & & + & & \\
\hline 2 & MRPS34 & $28 \mathrm{~S}$ ribosomal protein $\mathrm{S} 34$, mitochondrial & & $\mathrm{D}$ & & & & + & & \\
\hline 16 & MRPS39 & Pentatricopeptide repeat-containing protein 3 , mitochondrial, PTCD3 & & & & & & + & & \\
\hline 3 & MRPS9 & $28 \mathrm{~S}$ ribosomal protein $\mathrm{S} 9$, mitochondrial & & & & & & + & & \\
\hline 4 & MSN & Moesin (membrane organizing extension spike protein) & $U$ & & $U$ & & $\begin{array}{l}\text { Nsp6O } \\
\text { rf3 }\end{array}$ & & + & $(94)$ \\
\hline 12 & MVP & Major vault protein & $\mathrm{U}$ & D & $\mathrm{U}$ & & & + & & (95) \\
\hline 16 & MYBBP1A & Myb-binding protein $1 \mathrm{~A}$ & $\mathrm{U}$ & $\mathrm{D}$ & $\mathrm{U}$ & & & + & & \\
\hline 2 & MYG1 & UPF0160 protein MYG1, mitochondrial & & & & & & & + & \\
\hline 14 & MYH9 & Myosin-9 & $\mathrm{U}$ & D & $\mathrm{U}$ & D & & & + & (96) \\
\hline 2 & MYO1E & Unconventional myosin-le, MYO1C & $\mathrm{U}$ & & & & & + & & (97) \\
\hline 3 & NAP1L1 & Nucleosome assembly protein 1 -like 1 & $\mathrm{U}$ & D & & $\mathrm{D}$ & & + & & \\
\hline 18 & $\mathrm{NCL}$ & Nucleolin & $\mathrm{U}$ & $\mathrm{D}$ & & & & + & & (98) \\
\hline 8 & NME1 & Nucleoside diphosphate kinase & $\mathrm{U}$ & $\mathrm{D}$ & & $\mathrm{D}$ & & & + & (99) \\
\hline 3 & NME2 & Nucleoside diphosphate kinase 2, NM23 & $\mathrm{U}$ & $\mathrm{D}$ & & & & & + & $(100)$ \\
\hline 2 & NOC2L & Nucleolar complex protein 2 homolog & & $\mathrm{D}$ & & D & & + & & \\
\hline 9 & NOP2 & Probable 28S rRNA (cytosine(4447)-C(5)-methyltransferase & $\mathrm{U}$ & & $\mathrm{U}$ & & & + & & \\
\hline 2 & NPEPPS & Puromycin-sensitive aminopeptidase, metalloproteinase MP100 & & & & & & & + & \\
\hline 6 & NPM1 & Nucleophosmin & $\mathrm{U}$ & $\mathrm{D}$ & $\mathrm{U}$ & $\mathrm{D}$ & & + & & (101) \\
\hline 2 & NRCAM & Neuronal cell adhesion molecule & $\mathrm{U}$ & $\mathrm{D}$ & $\mathrm{U}$ & D & & & + & (102) \\
\hline 4 & NUDT21 & Cleavage and polyadenylation specificity factor subunit 5 & & $\mathrm{D}$ & & $\mathrm{D}$ & & & + & \\
\hline 2 & OLA1 & Obg-like ATPase 1 & $\mathrm{U}$ & & $\mathrm{U}$ & & & & + & \\
\hline 11 & $\mathrm{P} 4 \mathrm{HB}$ & Protein disulfide-isomerase & $\mathrm{U}$ & $\mathrm{D}$ & $\mathrm{U}$ & D & & & + & (103) \\
\hline 22 & PABPC1 & Polyadenylate-binding protein 1 & & $\mathrm{D}$ & & $\mathrm{D}$ & $\mathrm{N}$ & + & & (104) \\
\hline 11 & PABPC4 & Polyadenylate-binding protein 4 & & $\mathrm{D}$ & & $\mathrm{D}$ & $\mathrm{N}$ & + & & (105) \\
\hline 4 & PAF1 & RNA polymerase II-associated factor 1 homolog & & D & & & & + & & \\
\hline 2 & PAFAH1B2 & Platelet-activating factor acetylhydrolase IB subunit beta & $\mathrm{U}$ & $\mathrm{D}$ & $\mathrm{U}$ & $\mathrm{D}$ & & & + & \\
\hline 3 & PAFAH1B3 & Platelet-activating factor acetylhydrolase IB subunit gamma & $\mathrm{U}$ & & U & & & & + & \\
\hline
\end{tabular}


bioRxiv preprint doi: https://doi.org/10.1101/2021.02.21.432171; this version posted February 22, 2021. The copyright holder for this preprint (which was not certified by peer review) is the author/funder, who has granted bioRxiv a license to display the preprint in perpetuity. It is made available under aCC-BY 4.0 International license.

\begin{tabular}{|c|c|c|c|c|c|c|c|c|c|c|}
\hline 6 & PCNA & Proliferating cell nuclear antigen & $U$ & $\mathrm{D}$ & $u$ & $\mathrm{D}$ & & & + & (106) \\
\hline 12 & PDIA3 & Protein disulfide-isomerase $\mathrm{A} 3$ & $\mathrm{U}$ & $\mathrm{D}$ & $\mathrm{U}$ & & Orf8 & & + & $(107)$ \\
\hline 18 & PDIA4 & Protein disulfide-isomerase A4 & $\mathrm{U}$ & $\mathrm{D}$ & $\mathrm{U}$ & & & & + & \\
\hline 10 & PDIA6 & Protein disulfide-isomerase $\mathrm{A} 6$ & $\mathrm{U}$ & $\mathrm{D}$ & $\mathrm{U}$ & D & & & + & $(108)$ \\
\hline 6 & PELP1 & Proline-, glutamic acid-, leucine-rich protein 1 & & $\mathrm{D}$ & & $\mathrm{D}$ & & + & & \\
\hline 2 & PES1 & Pescadillo homolog & & $\mathrm{D}$ & & & & + & & \\
\hline 2 & PFAS & $\begin{array}{l}\text { Phosphoribosylformylglycinamidine synthase, GATD8, FGARAT, } \\
\text { PURL }\end{array}$ & & & & & & & + & \\
\hline 2 & PFKP & ATP-dependent 6-phofructokinase, platelet type & $\mathrm{U}$ & $\mathrm{D}$ & $\mathrm{U}$ & & Orf7a & & + & (109) \\
\hline 2 & PGAM2 & Phosphoglycerate mutase, PGAMM & & & & & & & + & \\
\hline 9 & PGD & 6-phosphogluconate dehydrogenase, decarboxylating & $\mathrm{U}$ & D & $\mathrm{U}$ & & & & + & \\
\hline 2 & PLD3 & Phospholipase D3, 5'-3' exonuclease PLD3 & $\mathrm{u}$ & $\mathrm{D}$ & & D & $\begin{array}{c}\text { Nsp2O } \\
\text { rf8 } \\
\text { Orf7b }\end{array}$ & & + & \\
\hline 39 & PLEC & Plectin-1 & $\mathrm{U}$ & $\mathrm{D}$ & $\mathrm{U}$ & $\mathrm{D}$ & & + & & (110) \\
\hline 2 & PLS1 & Plastin-1 & & $\mathrm{D}$ & & & & & + & \\
\hline 5 & PLS3 & Plastin-3 & $\mathrm{U}$ & $\mathrm{D}$ & & & & & + & \\
\hline 2 & POP1 & Ribonucleases P/MRP protein subunit POP1 & $\mathrm{U}$ & & & & & + & & (111) \\
\hline 3 & POR & NADPH--cytochrome P450 reductase & $\mathrm{U}$ & $\mathrm{D}$ & $\mathrm{U}$ & & Nsp2 & + & & \\
\hline 2 & PPA1 & Inorganic pyrophosphatase (Guillain-Barre syndrome) & U & & & & Orf3 & & + & (112) \\
\hline 5 & PPIB & Peptidyl-prolyl cis-trans isomerase & U & $\mathrm{D}$ & $\mathrm{U}$ & & & & + & (113) \\
\hline 6 & PRDX1 & Peroxiredoxin-1 & $\mathrm{U}$ & $\mathrm{D}$ & $\mathrm{U}$ & $\mathrm{D}$ & & & + & (114) \\
\hline 4 & PRDX3 & Thioredoxin-dependent peroxide reductase, mitochondrial & $\mathrm{U}$ & $\mathrm{D}$ & $\mathrm{U}$ & & & & + & (115) \\
\hline 3 & PRDX4 & Peroxiredoxin-4 & U & $\mathrm{D}$ & & & & & + & $(116)$ \\
\hline 17 & PRKDC & DNA-dependent protein kinase catalytic subunit & $U$ & $\mathrm{D}$ & U & & $\begin{array}{c}\text { M } \\
\text { Nsp4 }\end{array}$ & + & & $(117)$ \\
\hline 3 & PRMT1 & HMT1, hnRNP methyltransferase-like 2 isoform & & $\mathrm{D}$ & & D & & & + & \\
\hline 19 & PRPF8 & Pre-mRNA-processing-splicing factor 8 & $\mathrm{U}$ & $\mathrm{D}$ & $\mathrm{U}$ & $\mathrm{D}$ & & + & & (29) \\
\hline 6 & PSAT1 & Phosphoserine aminotransferase 1 & $U$ & $\mathrm{D}$ & U & & $\begin{array}{l}\text { Orf3 } \\
\text { Orf7a }\end{array}$ & & + & \\
\hline 2 & PSMD1 & 26S proteasome non-ATPase regulatory subunit 1 & $U$ & & U & & & + & & \\
\hline 2 & PSMD6 & $26 \mathrm{~S}$ proteasome non-ATPase regulatory subunit 6 , PFAAP4 & & & & & & & + & \\
\hline 18 & PUM1 & Pumilio homolog 1 & & $\mathrm{D}$ & & $\mathrm{D}$ & & + & & \\
\hline 3 & PURA & Transcriptional activator protein Pur-alpha & $\mathrm{U}$ & $\mathrm{D}$ & U & $\mathrm{D}$ & & + & & \\
\hline 2 & PURH & Bifunctional purine biosynthesis protein, ATIC & & & & & & & + & (118) \\
\hline 4 & QARS & Glutaminyl-tRNA synthetase & & & & & & + & & (83) \\
\hline 3 & RAB1A & Ras-related protein Rab-1A (intracellular membrane trafficking) & & $\mathrm{D}$ & & & $\begin{array}{c}\text { Nsp7 } \\
\text { Orf3 } \\
\text { Orf7b }\end{array}$ & + & & \\
\hline 6 & RALY & RNA-binding protein, autoantigen p542 & $\mathrm{U}$ & $\mathrm{D}$ & $\mathrm{U}$ & $\mathrm{D}$ & & + & & (119) \\
\hline 2 & RANGAP1 & Ran GTPase-activating protein 1 & & $\mathrm{D}$ & & & & + & & (120) \\
\hline 3 & RARS & Arginyl-tRNA synthetase, cytoplasmic, RARS1 & $\mathrm{U}$ & & $\mathrm{U}$ & & & + & & \\
\hline 5 & RBBP4 & Histone-binding protein RBBP4 & & $\mathrm{D}$ & & & & + & & $(121)$ \\
\hline 3 & RBM8A & RNA-binding protein $8 \mathrm{~A}$ & $\mathrm{U}$ & & & & & + & & \\
\hline 8 & $\mathrm{RDX}$ & Radixin & & & & & $\begin{array}{l}\text { Nsp13 } \\
\text { Orf3 }\end{array}$ & & + & $(122)$ \\
\hline 3 & RNPEP & Arginine aminopeptidase, APB & & & & & & & + & \\
\hline 2 & RNPS1 & RNA-binding protein with serine-rich domain 1 & $\mathrm{U}$ & $\mathrm{D}$ & $\mathrm{U}$ & D & & + & & \\
\hline 4 & $\mathrm{RO} 60$ & 60 kDa SS-A/Ro ribonucleoprotein & $\mathrm{U}$ & & $\mathrm{U}$ & & & + & & (123) \\
\hline 3 & RPF2 & Ribosome production factor 2 homolog, BXDC1 & & & & & & + & & \\
\hline 4 & RPL10A & $60 S$ ribosomal protein L10A, NEDD6 & & & & & & + & & \\
\hline 2 & RPL11 & $60 \mathrm{~S}$ ribosomal protein L11 & U & & $u$ & & & + & & \\
\hline 4 & RPL12 & 60 S ribosomal protein $\mathrm{L} 12$ & $\mathrm{U}$ & $\mathrm{D}$ & $\mathrm{U}$ & & & + & & (124) \\
\hline 3 & RPL15 & 60S ribosomal protein $\mathrm{L} 15$ & & $\mathrm{D}$ & & $\mathrm{D}$ & & + & & \\
\hline 3 & RPL18 & $60 S$ ribosomal protein L18 & & $\mathrm{D}$ & & D & & + & & \\
\hline 2 & RPL26L1 & 60 S ribosomal protein L26-like 1, RPL26P1 & & & & & & + & & \\
\hline 2 & RPL35A & $60 \mathrm{~S}$ ribosomal protein L35a & $\mathrm{U}$ & D & $\mathrm{U}$ & & & + & & (125) \\
\hline 2 & RPL4 & $60 S$ ribosomal protein $L 4$ & $\mathrm{U}$ & $\mathrm{D}$ & U & $\mathrm{D}$ & & + & & \\
\hline 17 & RPL5 & $60 S$ ribosomal protein L5 & & $\mathrm{D}$ & & D & & + & & (126) \\
\hline 11 & RPL6 & $60 S$ ribosomal protein L6 & $\mathrm{U}$ & $\mathrm{D}$ & $\mathrm{U}$ & $\mathrm{D}$ & & + & & (127) \\
\hline 9 & RPL7 & $60 S$ ribosomal protein $\mathrm{L} 7, \mathrm{RPL7P} 32$ & U & $\mathrm{D}$ & U & $\mathrm{D}$ & & + & & (128) \\
\hline 4 & RPL7A & $60 S$ ribosomal protein L7A & 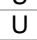 & $\mathrm{D}$ & & $\mathrm{D}$ & & + & & $(125)$ \\
\hline 2 & RPL8 & $60 S$ ribosomal protein L8 & $\mathrm{U}$ & $\mathrm{D}$ & $\mathrm{U}$ & $\mathrm{D}$ & & + & & (120) \\
\hline 8 & RPLPO & 60S acidic ribosomal protein P0 & $\mathrm{U}$ & $\mathrm{D}$ & u & & & + & & (129) \\
\hline 2 & RPLP1 & $60 \mathrm{~S}$ acidic ribosomal protein $\mathrm{P} 1$ & $\mathrm{U}$ & $\mathrm{D}$ & & D & & + & & $(130)$ \\
\hline 3 & RPLP2 & 605 acidic ribosomal protein P2 & $u$ & $\mathrm{D}$ & $u$ & $\mathrm{D}$ & & + & & $(130)$ \\
\hline 2 & RPS15A & $40 \mathrm{~S}$ ribosomal protein S15a & $\mathrm{U}$ & & & & & + & & \\
\hline 3 & RPS18 & 40S ribosomal protein S18 & U & $\mathrm{D}$ & & & & + & & (120) \\
\hline 3 & RPS2 & 40S ribosomal protein S2 & $\mathrm{U}$ & $\mathrm{D}$ & $\mathrm{U}$ & D & & + & & \\
\hline 3 & RPS3 & $40 S$ ribosomal protein S3 & $\mathrm{U}$ & $\mathrm{D}$ & $u$ & & & + & & (131) \\
\hline 4 & RPS4X & $40 \mathrm{~S}$ ribosomal protein $\mathrm{S} 4, \mathrm{X}$ isoform & & $\mathrm{D}$ & & D & & + & & \\
\hline 3 & RPS6 & 40 S ribosomal protein S6 & $\mathrm{U}$ & $\mathrm{D}$ & $\mathrm{U}$ & D & & + & & (125) \\
\hline 2 & RPS8 & 40 S ribosomal protein S8 & $\mathrm{U}$ & $\mathrm{D}$ & $u$ & & & + & & \\
\hline 8 & RPS9 & 40S ribosomal protein S9 & & $\mathrm{D}$ & & & & + & & (125) \\
\hline 4 & RPSA & 40S ribosomal protein SA, LMAR1 & & & & & & & + & (132) \\
\hline 2 & RRBP1 & Ribosome-binding protein 1 & $\mathrm{U}$ & $\mathrm{D}$ & & $\mathrm{D}$ & & + & & \\
\hline
\end{tabular}


bioRxiv preprint doi: https://doi.org/10.1101/2021.02.21.432171; this version posted February 22, 2021. The copyright holder for this preprint (which was not certified by peer review) is the author/funder, who has granted bioRxiv a license to display the preprint in perpetuity. It is made available under aCC-BY 4.0 International license.

\begin{tabular}{|c|c|c|c|c|c|c|c|c|c|c|}
\hline 11 & RRP12 & RRP12-like protein & $U$ & & & & & + & & \\
\hline 3 & RRP9 & U3 small nucleolar RNA-interacting protein 2 (U3-55K) & U & $\mathrm{D}$ & & & $\mathrm{N}$ & + & & (133) \\
\hline 4 & RRS1 & Ribosome biogenesis regulatory protein homolog & $\mathrm{U}$ & & $\mathrm{U}$ & & & + & & \\
\hline 5 & RSL1D1 & Ribosomal L1 domain-containing protein 1 & $\mathrm{U}$ & $\mathrm{D}$ & $\mathrm{U}$ & & & + & & \\
\hline 2 & RUVBL1 & RuvB-like 1 & & & & & & + & & (134) \\
\hline 13 & SAP130 & Histone deacetylase complex subunit SAP130 & $\mathrm{U}$ & & $\mathrm{U}$ & & & + & & \\
\hline 5 & SERPINB1 & Leukocyte elastase inhibitor & $\mathrm{U}$ & & & & & & + & \\
\hline 4 & SERPINB6 & Serpin B6, peptidase inhibitor 6 & & & & & & & + & \\
\hline 2 & SERPINC1 & Antithrombin-III & $\mathrm{U}$ & & & & & & + & \\
\hline 6 & SET & Protein SET, phosphatase $2 \mathrm{~A}$ inhibitor & $\mathrm{U}$ & $\mathrm{D}$ & & D & & + & & \\
\hline 14 & SF3B1 & Splicing factor $3 \mathrm{~B}$ subunit 1 & $\mathrm{U}$ & D & & D & & + & & (135) \\
\hline 8 & SFN & $14-3-3$ protein sigma & $\mathrm{U}$ & D & $\mathrm{U}$ & & & & + & (136) \\
\hline 2 & SLC1A5 & $\begin{array}{l}\text { Neutral amino acid transporter B, Simian type D retrovirus receptor, } \\
\text { Baboon M7 virus receptor }\end{array}$ & $\mathrm{U}$ & D & $\mathrm{U}$ & & & + & & \\
\hline 2 & SLC2A1 & $\begin{array}{l}\text { HepG2 glucose transporter, human T-cell leukemia virus receptor, } \\
\text { GLUT1 }\end{array}$ & & $\mathrm{D}$ & & $\mathrm{D}$ & Nsp8 & + & & (137) \\
\hline 17 & SLC3A2 & 4F2 cell-surface antigen heavy chain & $\mathrm{U}$ & $\mathrm{D}$ & $\mathrm{U}$ & & & + & & \\
\hline 2 & SND1 & Staphylococcal nuclease domain-containing protein 1 & $\mathrm{U}$ & D & & D & & & + & \\
\hline 15 & SNRNP200 & U5 small nuclear ribonucleoprotein $200 \mathrm{kDa}$ helicase & & $\mathrm{D}$ & & $\mathrm{D}$ & & + & & (138) \\
\hline 3 & SNRPA & U1 small nuclear ribonucleoprotein A & $\mathrm{U}$ & & & & & + & & (139) \\
\hline 2 & SNRPB & Small nuclear ribonucleoprotein-associated proteins B and B' & U & $\mathrm{D}$ & $\mathrm{U}$ & $\mathrm{D}$ & & + & & (140) \\
\hline 2 & SNRPD1 & Small nuclear ribonucleoprotein Sm D1 & $\mathrm{U}$ & & $\mathrm{U}$ & & & + & & (141) \\
\hline 4 & SNRPD2 & Small nuclear ribonucleoprotein Sm D2 & & $\mathrm{D}$ & & $\mathrm{D}$ & & + & & (142) \\
\hline 2 & SNRPG & Small nuclear ribonucleoprotein G, PBSCG & & & & & & + & & $\begin{array}{l}\text { (Satoh, } \\
\text { Chan et } \\
\text { al. }\end{array}$ \\
\hline 2 & SOD1 & Superoxide dismutase [Cu-Zn] & $\mathrm{U}$ & D & & & & & + & (143) \\
\hline 46 & SPTAN1 & Spectrin alpha chain, brain & u & $\mathrm{D}$ & & $\mathrm{D}$ & & + & & (144) \\
\hline 29 & SPTBN1 & Spectrin beta chain, brain 1 & $\mathrm{U}$ & D & $\mathrm{U}$ & D & & + & & (145) \\
\hline 2 & SRP72 & Signal recognition particle $72 \mathrm{kDa}$ protein & & D & & D & & + & & (146) \\
\hline 3 & SRSF1 & Serine arginine rich splicing factor $1, \mathrm{ASF}, \mathrm{SF} 2$ & $\mathrm{U}$ & D & & D & & + & & (147) \\
\hline 6 & SSB & Lupus La protein & $\mathrm{U}$ & D & $\mathrm{U}$ & D & & & + & (59) \\
\hline 9 & SSBP1 & Single-stranded DNA-binding protein, mitochondrial & & & & & $\mathrm{N}$ & + & & \\
\hline 8 & SSRP1 & FACT complex subunit SSRP1 & $\mathrm{U}$ & D & $\mathrm{U}$ & D & & + & & (148) \\
\hline 2 & ST13 & Hsc70-interacting protein & $\mathrm{U}$ & & $\mathrm{U}$ & & & & + & (149) \\
\hline 9 & SUPT16H & FACT complex subunit SPT16 & & D & & D & & + & & \\
\hline 2 & SUPT5H & Transcription elongation factor SPT5 & & & & & & + & & \\
\hline 2 & SYNCRIP & Heterogeneous nuclear ribonucleoprotein $Q$ & & D & & D & & + & & \\
\hline 11 & TALDO1 & Transaldolase & $\mathrm{U}$ & D & $\mathrm{U}$ & D & & & + & $(150)$ \\
\hline 4 & TEX10 & Testis-expressed protein 10 & & & & & & + & & \\
\hline 3 & TFG & TRK-fused gene protein & & & & & & & + & \\
\hline 4 & TGM2 & Protein-glutamine gamma-glutamyltransferase 2 & $\mathrm{U}$ & $\mathrm{D}$ & $\mathrm{U}$ & $\mathrm{D}$ & & & + & $(151)$ \\
\hline 4 & TLN1 & Talin-1 & U & D & $\mathrm{U}$ & & & & + & (152) \\
\hline 3 & TOP1 & DNA topoisomerase 1 & $\mathrm{U}$ & & & & & + & & (153) \\
\hline 5 & TP53І3 & Quinone oxidoreductase & U & D & $\mathrm{U}$ & D & & & + & \\
\hline 7 & TPM1 & Tropomyosin 1 alpha chain & U & D & U & D & & & + & (154) \\
\hline 2 & TPM2 & Tropomyosin beta chain & U & D & $\mathrm{U}$ & D & & & + & \\
\hline 4 & TPM3 & Tropomyosin alpha-3 chain & U & D & $\mathrm{U}$ & D & & & + & (155) \\
\hline 8 & TPM4 & Tropomyosin alpha-4 chain & U & $\mathrm{D}$ & $\mathrm{U}$ & & & & + & (156) \\
\hline 3 & TSN & Translin & & $\mathrm{D}$ & & $\mathrm{D}$ & & & + & \\
\hline 4 & TUBA1C & Tubulin alpha-1C chain & U & D & $\mathrm{U}$ & D & & + & & (157) \\
\hline 5 & TUBA4A & Tubulin alpha-4A chain & $\mathrm{U}$ & $\mathrm{D}$ & & $\mathrm{D}$ & & + & & (158) \\
\hline 4 & TUBB4B & Tubulin beta-2C chain, TUBB2C & $\mathrm{U}$ & D & U & & & + & & (159) \\
\hline 2 & TXNDC5 & Thioredoxin domain-containing protein 5 & $\mathrm{U}$ & D & $\mathrm{U}$ & D & & & + & \\
\hline 15 & TXNRD1 & Thioredoxin reductase 1 , cytoplasmic & $\mathrm{U}$ & $\mathrm{D}$ & $\mathrm{U}$ & & & & + & $(160)$ \\
\hline 7 & UBA1 & Ubiquitin-like modifier-activating enzyme 1 & $\mathrm{U}$ & $\mathrm{D}$ & $\mathrm{U}$ & D & & & + & (161) \\
\hline 3 & UBC & RPS27A; UBB ubiquitin-40S ribosomal protein S27a precursor & $\mathrm{U}$ & D & & & & + & & (162) \\
\hline 2 & UBTF & Nucleolar transcription factor 1 , autoantigen NOR-90 & & D & & D & & + & & (163) \\
\hline 2 & UCHL1 & Ubiquitin carboxyl-terminal hydrolase isozyme L1 & $\mathrm{U}$ & $\mathrm{D}$ & $\mathrm{U}$ & $\mathrm{D}$ & Orf3 & & + & (164) \\
\hline 5 & UGDH & UDP-glucose 6-dehydrogenase & $\mathrm{U}$ & $\mathrm{D}$ & $\mathrm{U}$ & & & & + & \\
\hline 15 & UPF1 & Regulator of nonsense transcripts 1 & & D & & & $\mathrm{N}$ & + & & \\
\hline 2 & USP7 & Ubiquitin carboxyl-terminal hydrolase (Herpes virus associated) & $\mathrm{U}$ & & $\mathrm{U}$ & & & + & & \\
\hline 27 & VCL & Vinculin & $\mathrm{U}$ & D & $\mathrm{U}$ & & & & + & (165) \\
\hline 18 & VCP & Transitional endoplasmic reticulum ATPase & $\mathrm{U}$ & D & $\mathrm{U}$ & $\mathrm{D}$ & & & + & (166) \\
\hline 11 & VIM & Vimentin & $\mathrm{U}$ & D & $\mathrm{U}$ & D & & + & & (167) \\
\hline 5 & WDR18 & WD repeat-containing protein 18 & & D & & & & + & & \\
\hline 32 & XRCC5 & ATP-dependent DNA helicase 2 subunit 2 & & D & & $\mathrm{D}$ & & + & & $(168)$ \\
\hline 30 & XRCC6 & ATP-dependent DNA helicase 2 subunit 1 & $\mathrm{U}$ & D & $\mathrm{U}$ & D & & + & & (169) \\
\hline 3 & YBX1 & Y-box-binding protein 1 & $\mathrm{U}$ & $\mathrm{D}$ & $\mathrm{U}$ & D & & + & & (170) \\
\hline 6 & YBX3 & Y-box binding protein $3, \mathrm{CSDA}$ & $\mathrm{U}$ & D & $\mathrm{U}$ & D & & + & & (171) \\
\hline 5 & YWHAB & 14-3-3 protein beta/alpha & $\mathrm{U}$ & D & & D & & & + & \\
\hline 15 & YWHAE & 14-3-3 protein epsilon & $\mathrm{U}$ & $\mathrm{D}$ & $\mathrm{U}$ & $\mathrm{D}$ & & & + & $(136)$ \\
\hline 6 & YWHAG & 14-3-3 protein gamma & $\mathrm{U}$ & D & & & & & + & (136) \\
\hline 3 & YWHAH & 14-3-3 protein eta & & D & & & & & + & (172) \\
\hline 7 & YWHAQ & 14-3-3 protein theta & $\mathrm{U}$ & D & $\mathrm{U}$ & & & & + & (132) \\
\hline
\end{tabular}


bioRxiv preprint doi: https://doi.org/10.1101/2021.02.21.432171; this version posted February 22, 2021. The copyright holder for this preprint (which was not certified by peer review) is the author/funder, who has granted bioRxiv a license to display the preprint in perpetuity. It is made available under aCC-BY 4.0 International license.

\begin{tabular}{l|l} 
U & D
\end{tabular}

D

(173)

Notes:

\# Pep.: number of peptides identified by mass spectrometry; COVID (up/down): protein or gene expression up-and/or down-regulated in SARS-Cov-2 infected cells or patients; A549 infection (up/down): protein or gene expression up- and/or down-regulated in SARSCov-2 infected A549 cells; Interactome: host protein interacting with SARS-CoV-2 protein; DS-affinity: concentration of $\mathrm{NaCl}$ (1.0 M, strong affinity, or $0.5 \mathrm{M}$, intermediate affinity) at which a DS-binding protein elutes from DS-affinity resin. 


\section{References for Table 1}

1. Saunders, R. D., S. T. Nakajima, S. N. Rai, J. Pan, C. Gercel-Taylor, and D. D. Taylor. 2012. Alterations in antibody subclass immune reactivity to trophoblast-derived fetal fibronectin and $\alpha 2$-macroglobulin in women with recurrent pregnancy loss. Am J Reprod Immunol 68: 438-449.

2. Petrohai, A., G. Nagy, S. Bosze, F. Hudecz, E. Zsiros, G. Paragh, Z. Nyárády, P. Németh, and T. Berki. 2005. Detection of citrate synthase-reacting autoantibodies after heart transplantation: an epitope mapping study. Transplant international : official journal of the European Society for Organ Transplantation 17: 834-840.

3. Mande, P. V., F. R. Parikh, I. Hinduja, K. Zaveri, R. Vaidya, R. Gajbhiye, and V. V. Khole. 2011. Identification and validation of candidate biomarkers involved in human ovarian autoimmunity. Reprod Biomed Online 23: 471-483.

4. van Beers, J. J., C. M. Schwarte, J. Stammen-Vogelzangs, E. Oosterink, B. Bozic, and G. J. Pruijn. 2013. The rheumatoid arthritis synovial fluid citrullinome reveals novel citrullinated epitopes in apolipoprotein $\mathrm{E}$, myeloid nuclear differentiation antigen, and beta-actin. Arthritis and rheumatism 65: 69-80.

5. Hanrotel-Saliou, C., I. Segalen, Y. Le Meur, P. Youinou, and Y. Renaudineau. 2011. Glomerular antibodies in lupus nephritis. Clin Rev Allergy Immunol 40: 151-158.

6. Bei, R., and G. J. Mizejewski. 2020. Alpha-fetoprotein is an autoantigen in hepatocellular carcinoma and juvenile Batten disease. Frontiers in bioscience (Landmark edition) 25: 912-929.

7. Rivner, M. H., B. M. Quarles, J. X. Pan, Z. Yu, J. F. Howard, Jr., A. Corse, M. M. Dimachkie, C. Jackson, T. Vu, G. Small, R. P. Lisak, J. Belsh, I. Lee, R. J. Nowak, V. Baute, S. Scelsa, J. A. Fernandes, Z. Simmons, A. Swenson, R. Barohn, R. B. Sanka, C. Gooch, E. Ubogu, J. Caress, M. Pasnoor, H. Xu, and L. Mei. 2020. Clinical features of LRP4/agrin-antibody-positive myasthenia gravis: A multicenter study. Muscle \& nerve 62: 333-343.

8. Prunotto, M., M. L. Carnevali, G. Candiano, C. Murtas, M. Bruschi, E. Corradini, A. Trivelli, A. Magnasco, A. Petretto, L. Santucci, S. Mattei, R. Gatti, F. Scolari, P. Kador, L. Allegri, and G. M. Ghiggeri. 2010. Autoimmunity in membranous nephropathy targets aldose reductase and SOD2. Journal of the American Society of Nephrology : JASN 21: 507-519.

9. Nehring, J., L. A. Schirmbeck, J. Friebus-Kardash, D. Dubler, U. Huynh-Do, C. Chizzolini, C. Ribi, and M. Trendelenburg. 2018. Autoantibodies Against Albumin in Patients With Systemic Lupus Erythematosus. Frontiers in immunology 9: 2090.

10. Edassery, S. L., S. V. Shatavi, J. P. Kunkel, C. Hauer, C. Brucker, K. Penumatsa, Y. Yu, J. A. Dias, and J. L. Luborsky. 2010. Autoantigens in ovarian autoimmunity associated with unexplained infertility and premature ovarian failure. Fertility and sterility 94: 2636-2641.

11. Cheng, K. C., Y. J. Wu, K. H. Cheng, K. Y. Cheng, K. J. Chen, W. C. Wu, P. Y. Lee, and C. H. Chang. 2018. Autoantibody against aldehyde dehydrogenase 2 could be a biomarker to monitor progression of Graves' orbitopathy. Graefe's archive for clinical and experimental ophthalmology = Albrecht von Graefes Archiv fur klinische und experimentelle Ophthalmologie 256: 11951201.

12. Privitera, D., V. Corti, M. Alessio, M. A. Volontè, V. Lampasona, G. Comi, G. Martino, D. Franciotta, R. Furlan, and R. Fazio. 2013. Proteomic identification of aldolase $A$ as an autoantibody target in patients with atypical movement disorders. Neurological sciences : official journal of the Italian Neurological Society and of the Italian Society of Clinical Neurophysiology 34: 313-320.

13. Pott, M. C., N. Frede, J. Wanders, L. Hammarström, E. O. Glocker, C. Glocker, F. Tahami, and B. Grimbacher. 2017. Autoantibodies against BAFF, APRIL or IL21 - an alternative pathogenesis for antibody-deficiencies? BMC immunology 18: 34.

14. Caster, D. J., E. A. Korte, M. L. Merchant, J. B. Klein, D. W. Wilkey, B. H. Rovin, D. J. Birmingham, J. B. Harley, B. L. Cobb, B. Namjou, K. R. McLeish, and D. W. Powell. 2015. Autoantibodies targeting glomerular annexin A2 identify patients with proliferative lupus nephritis. Proteomics Clin App/ 9: 1012-1020.

15. Scholz, P., M. Auler, B. Brachvogel, T. Benzing, P. Mallman, T. Streichert, and A. R. Klatt. 2016. Detection of multiple annexin autoantibodies in a patient with recurrent miscarriages, fulminant stroke and seronegative antiphospholipid syndrome. Biochemia medica 26: 272-278.

16. Satoh, A., K. Suzuki, E. Takayama, K. Kojima, T. Hidaka, M. Kawakami, I. Matsumoto, and F. Ohsuzu. 1999. Detection of antiannexin IV and $V$ antibodies in patients with antiphospholipid syndrome and systemic lupus erythematosus. The Journal of rheumatology 26: 1715-1720.

17. Hrycek, A., and P. Cieślik. 2012. Annexin A5 and anti-annexin antibodies in patients with systemic lupus erythematosus. Rheumatol Int 32: 1335-1342.

18. Seko, Y., A. Matsumoto, T. Fukuda, Y. Imai, T. Fujimura, H. Taka, R. Mineki, K. Murayama, Y. Hirata, and R. Nagai. 2007. A case of neonatal lupus erythematosus presenting delayed dilated cardiomyopathy with circulating autoantibody to annexin A6. Int Heart J 48: 407-415.

19. Jarius, S., and B. Wildemann. 2015. 'Medusa head ataxia': the expanding spectrum of Purkinje cell antibodies in autoimmune cerebellar ataxia. Part 3: Anti-Yo/CDR2, anti-Nb/AP3B2, PCA-2, anti-Tr/DNER, other antibodies, diagnostic pitfalls, summary and outlook. Journal of neuroinflammation 12: 168. 
20. Katsumata, Y., Y. Kawaguchi, S. Baba, S. Hattori, K. Tahara, K. Ito, T. Iwasaki, N. Yamaguchi, M. Oyama, H. Kozuka-Hata, H. Hattori, K. Nagata, H. Yamanaka, and M. Hara. 2011. Identification of three new autoantibodies associated with systemic lupus erythematosus using two proteomic approaches. Molecular \& cellular proteomics : MCP 10: M110.005330.

21. Krishnan, B., C. Massilamany, R. H. Basavalingappa, A. Gangaplara, R. A. Rajasekaran, M. Z. Afzal, V. Khalilzad-Sharghi, Y. Zhou, J. J. Riethoven, S. S. Nandi, P. K. Mishra, R. A. Sobel, J. L. Strande, D. Steffen, and J. Reddy. 2018. Epitope Mapping of SERCA2a Identifies an Antigenic Determinant That Induces Mainly Atrial Myocarditis in A/J Mice. Journal of immunology (Baltimore, Md. : 1950) 200: 523-537.

22. Creaney, J., I. M. Dick, D. Yeoman, S. Wong, and B. W. Robinson. 2011. Auto-antibodies to $\beta$-F1-ATPase and vimentin in malignant mesothelioma. PloS one 6: e26515.

23. Beutgen, V. M., C. Schmelter, N. Pfeiffer, and F. H. Grus. 2020. Autoantigens in the trabecular meshwork and glaucomaspecific alterations in the natural autoantibody repertoire. Clinical \& translational immunology 9: e01101.

24. Kishore, U., R. D. Sontheimer, K. N. Sastry, E. G. Zappi, G. R. Hughes, M. A. Khamashta, K. B. Reid, and P. Eggleton. 1997. The systemic lupus erythematosus (SLE) disease autoantigen-calreticulin can inhibit C1q association with immune complexes. Clinical and experimental immunology 108: 181-190.

25. Weber, C. K., M. Haslbeck, M. Englbrecht, B. Sehnert, D. Mielenz, D. Graef, J. H. Distler, R. B. Mueller, H. Burkhardt, G. Schett, R. E. Voll, and B. G. Furnrohr. 2010. Antibodies to the endoplasmic reticulum-resident chaperones calnexin, BiP and Grp94 in patients with rheumatoid arthritis and systemic lupus erythematosus. Rheumatology (Oxford, England) 49: 22552263.

26. Li, W. H., J. Zhao, H. Y. Li, H. Liu, A. L. Li, H. X. Wang, J. Wang, K. He, B. Liang, M. Yu, B. F. Shen, and X. M. Zhang. 2006. Proteomics-based identification of autoantibodies in the sera of healthy Chinese individuals from Beijing. Proteomics 6 : 4781-4789.

27. Hirai, K., H. Maeda, K. Omori, T. Yamamoto, S. Kokeguchi, and S. Takashiba. 2013. Serum antibody response to group II chaperonin from Methanobrevibacter oralis and human chaperonin CCT. Pathog Dis 68: 12-19.

28. Goto, M., K. Kuribayashi, Y. Takahashi, T. Kondoh, M. Tanaka, D. Kobayashi, and N. Watanabe. 2013. Identification of autoantibodies expressed in acquired aplastic anaemia. British journal of haematology 160: 359-362.

29. Rho, J. H., W. Zhang, M. Murali, M. H. Roehrl, and J. Y. Wang. 2011. Human proteins with affinity for dermatan sulfate have the propensity to become autoantigens. Am J Pathol 178: 2177-2190.

30. Vece, T. J., L. B. Watkin, S. Nicholas, D. Canter, M. C. Braun, R. P. Guillerman, K. W. Eldin, G. Bertolet, S. McKinley, M. de Guzman, L. Forbes, I. Chinn, and J. S. Orange. 2016. Copa Syndrome: a Novel Autosomal Dominant Immune Dysregulatory Disease. J Clin Immunol 36: 377-387.

31. Garcia, M. C., J. Zhou, D. Henning, F. C. Arnett, and B. C. Valdez. 2000. Unique epitopes in RNA helicase II/Gu protein recognized by serum from a watermelon stomach patient. Molecular immunology 37: 351-359.

32. Scofield, R. H. 2010. Do we need new autoantibodies in lupus? Arthritis research \& therapy 12: 120.

33. Dai, L., J. Li, J. J. Tsay, T. A. Yie, J. S. Munger, H. Pass, W. N. Rom, E. M. Tan, and J. Y. Zhang. 2017. Identification of autoantibodies to ECH1 and HNRNPA2B1 as potential biomarkers in the early detection of lung cancer. Oncoimmunology 6: e1310359.

34. Kim, E. G., S. H. Kwak, D. Hwang, E. C. Yi, K. S. Park, B. K. Koo, and K. M. Kim. 2016. The Level of Autoantibodies Targeting Eukaryote Translation Elongation Factor $1 \alpha 1$ and Ubiquitin-Conjugating Enzyme 2 L3 in Nondiabetic Young Adults. Diabetes Metab J 40: 154-160.

35. Mooney, C. J., E. J. Dunphy, B. Stone, and D. G. McNeel. 2006. Identification of autoantibodies elicited in a patient with prostate cancer presenting as dermatomyositis. Int J Urol 13: 211-217.

36. Fernández-Madrid, F., N. Tang, H. Alansari, J. L. Granda, L. Tait, K. C. Amirikia, M. Moroianu, X. Wang, and R. L. Karvonen. 2004. Autoantibodies to Annexin XI-A and Other Autoantigens in the Diagnosis of Breast Cancer. Cancer research 64: 50895096.

37. Bach, M., G. Winkelmann, and R. Luhrmann. 1989. 20S small nuclear ribonucleoprotein U5 shows a surprisingly complex protein composition. Proceedings of the National Academy of Sciences of the United States of America 86: 6038-6042.

38. Heo, C. K., H. M. Hwang, H. J. Lee, S. S. Kwak, J. S. Yoo, D. Y. Yu, K. J. Lim, S. Lee, and E. W. Cho. 2019. Serum anti-EIF3A autoantibody as a potential diagnostic marker for hepatocellular carcinoma. Sci Rep 9: 11059.

39. Betteridge, Z., H. Chinoy, J. Vencovsky, J. Winer, K. Putchakayala, P. Ho, I. Lundberg, K. Danko, R. Cooper, and N. McHugh. 2020. Identification of a novel autoantigen eukaryotic initiation factor 3 associated with polymyositis. Rheumatology (Oxford, England) 59: 1026-1030.

40. Pagaza-Straffon, C., L. A. Marchat, L. Herrera, J. Díaz-Chávez, M. G. Avante, Y. P. Rodríguez, M. C. Arreola, and C. LópezCamarillo. 2020. Evaluation of a panel of tumor-associated antigens in breast cancer. Cancer biomarkers : section A of Disease markers 27: 207-211.

41. Moscato, S., F. Pratesi, A. Sabbatini, D. Chimenti, M. Scavuzzo, R. Passatino, S. Bombardieri, A. Giallongo, and P. Migliorini. 2000. Surface expression of a glycolytic enzyme, alpha-enolase, recognized by autoantibodies in connective tissue disorders. Eur J Immunol 30: 3575-3584. 
42. Akatsuka, T., N. Kobayashi, T. Ishikawa, T. Saito, M. Shindo, M. Yamauchi, K. Kurokohchi, H. Miyazawa, H. Duan, T. Matsunaga, T. Komoda, C. Morisseau, and B. D. Hammock. 2007. Autoantibody response to microsomal epoxide hydrolase in hepatitis $C$ and $A$. Journal of autoimmunity 28: 7-18.

43. Leveque, C., T. Hoshino, P. David, Y. Shoji-Kasai, K. Leys, A. Omori, B. Lang, O. el Far, K. Sato, N. Martin-Moutot, and et al. 1992. The synaptic vesicle protein synaptotagmin associates with calcium channels and is a putative Lambert-Eaton myasthenic syndrome antigen. Proceedings of the National Academy of Sciences of the United States of America 89: 36253629.

44. Capello, M., P. Cappello, F. C. Linty, R. Chiarle, I. Sperduti, A. Novarino, P. Salacone, G. Mandili, A. Naccarati, C. Sacerdote, S. Beghelli, S. Bersani, S. Barbi, C. Bassi, A. Scarpa, P. Nisticò, M. Giovarelli, P. Vineis, M. Milella, and F. Novelli. 2013. Autoantibodies to Ezrin are an early sign of pancreatic cancer in humans and in genetically engineered mouse models. Journal of hematology \& oncology 6: 67.

45. Desmetz, C., C. Bascoul-Mollevi, P. Rochaix, P. J. Lamy, A. Kramar, P. Rouanet, T. Maudelonde, A. Mangé, and J. Solassol. 2009. Identification of a new panel of serum autoantibodies associated with the presence of in situ carcinoma of the breast in younger women. Clinical cancer research : an official journal of the American Association for Cancer Research 15: 47334741.

46. Kamhieh-Milz, J., V. Sterzer, H. Celik, O. Khorramshahi, R. Fadl Hassan Moftah, and A. Salama. 2017. Identification of novel autoantigens via mass spectroscopy-based antibody-mediated identification of autoantigens (MS-AMIDA) using immune thrombocytopenic purpura (ITP) as a model disease. Journal of proteomics 157: 59-70.

47. Adachi-Hayama, M., A. Adachi, N. Shinozaki, T. Matsutani, T. Hiwasa, M. Takiguchi, N. Saeki, and Y. Iwadate. 2014. Circulating anti-filamin C autoantibody as a potential serum biomarker for low-grade gliomas. BMC Cancer 14: 452.

48. Dong, X., M. Yang, H. Sun, J. Lü, Z. Zheng, Z. Li, and L. Zhong. 2013. Combined measurement of CA 15-3 with novel autoantibodies improves diagnostic accuracy for breast cancer. Onco Targets Ther 6: 273-279.

49. Terrier, B., M. C. Tamby, L. Camoin, P. Guilpain, C. Broussard, G. Bussone, A. Yaïci, F. Hotellier, G. Simonneau, L. Guillevin, M. Humbert, and L. Mouthon. 2008. Identification of target antigens of antifibroblast antibodies in pulmonary arterial hypertension. American journal of respiratory and critical care medicine 177: 1128-1134.

50. Kit, Y., M. Starykovych, M. Vajrychova, J. Lenco, D. Zastavna, and R. Stoika. 2014. Detection of novel auto-antigens in patients with recurrent miscarriage: description of an approach and preliminary findings. Croat Med J 55: 259-264.

51. Delunardo, F., D. Soldati, V. Bellisario, A. Berry, S. Camerini, M. Crescenzi, C. Alessandri, F. Conti, F. Ceccarelli, A. Francia, G. Valesini, F. Cirulli, A. Siracusano, A. Siracusano, C. Niolu, I. Alex Rubino, E. Ortona, and P. Margutti. 2016. Anti-GAPDH Autoantibodies as a Pathogenic Determinant and Potential Biomarker of Neuropsychiatric Diseases. Arthritis \& rheumatology (Hoboken, N.J.) 68: 2708-2716.

52. Kiyota, A., S. Iwama, Y. Sugimura, S. Takeuchi, H. Takagi, N. Iwata, K. Nakashima, H. Suzuki, T. Nishioka, T. Kato, A. Enomoto, H. Arima, K. Kaibuchi, and Y. Oiso. 2015. Identification of the novel autoantigen candidate Rab GDP dissociation inhibitor alpha in isolated adrenocorticotropin deficiency. Endocrine journal 62: 153-160.

53. Massa, O., M. Alessio, L. Russo, G. Nardo, V. Bonetto, F. Bertuzzi, A. Paladini, D. lafusco, P. Patera, G. Federici, T. Not, C. Tiberti, R. Bonfanti, and F. Barbetti. 2013. Serological Proteome Analysis (SERPA) as a tool for the identification of new candidate autoantigens in type 1 diabetes. Journal of proteomics 82: 263-273.

54. Carlsson, L., G. Ronquist, B. O. Nilsson, and A. Larsson. 2004. Dominant prostasome immunogens for sperm-agglutinating autoantibodies of infertile men. Journal of andrology 25: 699-705.

55. Muraki, Y., I. Matsumoto, Y. Chino, T. Hayashi, E. Suzuki, D. Goto, S. Ito, H. Murata, A. Tsutsumi, and T. Sumida. 2004. Glucose-6-phosphate isomerase variants play a key role in the generation of anti-GPI antibodies: possible mechanism of autoantibody production. Biochemical and biophysical research communications 323: 518-522.

56. Yang, J., G. Tezel, R. V. Patil, C. Romano, and M. B. Wax. 2001. Serum autoantibody against glutathione S-transferase in patients with glaucoma. Investigative ophthalmology \& visual science 42: 1273-1276.

57. Rubin, R. L., S. A. Bell, and R. W. Burlingame. 1992. Autoantibodies associated with lupus induced by diverse drugs target a similar epitope in the (H2A-H2B)-DNA complex. The Journal of clinical investigation 90: 165-173.

58. Burlingame, R. W., M. L. Boey, G. Starkebaum, and R. L. Rubin. 1994. The central role of chromatin in autoimmune responses to histones and DNA in systemic lupus erythematosus. The Journal of clinical investigation 94: 184-192.

59. Gruber, C. N., R. S. Patel, R. Trachtman, L. Lepow, F. Amanat, F. Krammer, K. M. Wilson, K. Onel, D. Geanon, K. Tuballes, M. Patel, K. Mouskas, T. O'Donnell, E. Merritt, N. W. Simons, V. Barcessat, D. M. Del Valle, S. Udondem, G. Kang, S. Gangadharan, G. Ofori-Amanfo, U. Laserson, A. Rahman, S. Kim-Schulze, A. W. Charney, S. Gnjatic, B. D. Gelb, M. Merad, and D. Bogunovic. 2020. Mapping Systemic Inflammation and Antibody Responses in Multisystem Inflammatory Syndrome in Children (MIS-C). Cell 183: 982-995.e914.

60. Wesierska-Gadek, J., E. Penner, H. Lindner, E. Hitchman, and G. Sauermann. 1990. Autoantibodies against different histone H1 subtypes in systemic lupus erythematosus sera. Arthritis and rheumatism 33: 1273-1278.

61. Baranova, S. V., P. S. Dmitrienok, N. V. Ivanisenko, V. N. Buneva, and G. A. Nevinsky. 2017. Antibodies to H2a and H2b histones from the sera of HIV-infected patients catalyze site-specific degradation of these histones. Molecular bioSystems 13: 1090-1101. 
62. Bruschi, M., M. Galetti, R. A. Sinico, G. Moroni, A. Bonanni, A. Radice, A. Tincani, F. Pratesi, P. Migliorini, C. Murtas, F. Franceschini, B. Trezzi, F. Brunini, R. Gatti, R. Tardanico, G. Barbano, G. Piaggio, P. Messa, P. Ravani, F. Scolari, G. Candiano, A. Martini, L. Allegri, and G. M. Ghiggeri. 2015. Glomerular Autoimmune Multicomponents of Human Lupus Nephritis In Vivo (2): Planted Antigens. Journal of the American Society of Nephrology : JASN 26: 1905-1924.

63. van Bavel, C. C., J. Dieker, S. Muller, J. P. Briand, M. Monestier, J. H. Berden, and J. van der Vlag. 2009. Apoptosis-associated acetylation on histone H2B is an epitope for lupus autoantibodies. Molecular immunology 47: 511-516.

64. Baranova, S. V., P. S. Dmitrenok, A. D. Zubkova, N. V. Ivanisenko, E. S. Odintsova, V. N. Buneva, and G. A. Nevinsky. 2018. Antibodies against $\mathrm{H} 3$ and $\mathrm{H} 4$ histones from the sera of HIV-infected patients catalyze site-specific degradation of these histones. Journal of molecular recognition : JMR 31: e2703.

65. Konig, M. F., J. T. Giles, P. A. Nigrovic, and F. Andrade. 2016. Antibodies to native and citrullinated RA33 (hnRNP A2/B1) challenge citrullination as the inciting principle underlying loss of tolerance in rheumatoid arthritis. Annals of the rheumatic diseases 75: 2022-2028.

66. Heegaard, N. H., M. R. Larsen, T. Muncrief, A. Wiik, and P. Roepstorff. 2000. Heterogeneous nuclear ribonucleoproteins $\mathrm{C} 1 / \mathrm{C} 2$ identified as autoantigens by biochemical and mass spectrometric methods. Arthritis research 2: 407-414.

67. Op De Beéck, K., L. Maes, K. Van den Bergh, R. Derua, E. Waelkens, K. Van Steen, P. Vermeersch, R. Westhovens, K. De Vlam, P. Verschueren, H. Hooijkaas, D. Blockmans, and X. Bossuyt. 2012. Heterogeneous nuclear RNPs as targets of autoantibodies in systemic rheumatic diseases. Arthritis and rheumatism 64: 213-221.

68. Yang, L., M. Fujimoto, H. Murota, S. Serada, M. Fujimoto, H. Honda, K. Yamada, K. Suzuki, A. Nishikawa, Y. Hosono, Y. Yoneda, K. Takehara, Y. Imura, T. Mimori, T. Takeuchi, I. Katayama, and T. Naka. 2015. Proteomic identification of heterogeneous nuclear ribonucleoprotein $\mathrm{K}$ as a novel cold-associated autoantigen in patients with secondary Raynaud's phenomenon. Rheumatology (Oxford, England) 54: 349-358.

69. Hassfeld, W., E. K. Chan, D. A. Mathison, D. Portman, G. Dreyfuss, G. Steiner, and E. M. Tan. 1998. Molecular definition of heterogeneous nuclear ribonucleoprotein R (hnRNP R) using autoimmune antibody: immunological relationship with hnRNP P. Nucleic Acids Res 26: 439-445.

70. Harlow, L., I. O. Rosas, B. R. Gochuico, T. R. Mikuls, P. F. Dellaripa, C. V. Oddis, and D. P. Ascherman. 2013. Identification of citrullinated hsp90 isoforms as novel autoantigens in rheumatoid arthritis-associated interstitial lung disease. Arthritis and rheumatism 65: 869-879.

71. Qin, H. Y., J. L. Mahon, M. A. Atkinson, P. Chaturvedi, E. Lee-Chan, and B. Singh. 2003. Type 1 diabetes alters anti-hsp90 autoantibody isotype. Journal of autoimmunity 20: 237-245.

72. Cid, C., I. Regidor, and A. Alcazar. 2007. Anti-heat shock protein 90beta antibodies are detected in patients with multiple sclerosis during remission. Journal of neuroimmunology 184: 223-226.

73. Suzuki, S., K. Utsugisawa, K. Iwasa, T. Satoh, Y. Nagane, H. Yoshikawa, M. Kuwana, and N. Suzuki. 2011. Autoimmunity to endoplasmic reticulum chaperone GRP94 in myasthenia gravis. Journal of neuroimmunology 237: 87-92.

74. Mišunová, M., T. Svitálková, L. Pleštilová, O. Kryštufková, D. Tegzová, R. Svobodová, M. Hušáková, M. Tomčík, R. Bečvář, J. Závada, H. Mann, L. Kolesár, A. Slavčev, J. Vencovský, and P. Novota. 2017. Molecular markers of systemic autoimmune disorders: the expression of MHC-located HSP70 genes is significantly associated with autoimmunity development. Clinical and experimental rheumatology 35: 33-42.

75. Shimizu, F., K. L. Schaller, G. P. Owens, A. C. Cotleur, D. Kellner, Y. Takeshita, B. Obermeier, T. J. Kryzer, Y. Sano, T. Kanda, V. A. Lennon, R. M. Ransohoff, and J. L. Bennett. 2017. Glucose-regulated protein 78 autoantibody associates with bloodbrain barrier disruption in neuromyelitis optica. Sci Transl Med 9.

76. Iannaccone, A., F. Giorgianni, D. D. New, T. J. Hollingsworth, A. Umfress, A. H. Alhatem, I. Neeli, N. I. Lenchik, B. J. Jennings, J. I. Calzada, S. Satterfield, D. Mathews, R. I. Diaz, T. Harris, K. C. Johnson, S. Charles, S. B. Kritchevsky, I. C. Gerling, S. Beranova-Giorgianni, M. Z. Radic, and A. B. C. s. Health. 2015. Circulating Autoantibodies in Age-Related Macular Degeneration Recognize Human Macular Tissue Antigens Implicated in Autophagy, Immunomodulation, and Protection from Oxidative Stress and Apoptosis. PloS one 10: e0145323.

77. Papp, D., Z. Prohászka, J. Kocsis, G. Füst, D. Bánhegyi, D. A. Raynes, and V. Guerriero. 2005. Development of a sensitive assay for the measurement of antibodies against heat shock protein binding protein 1 (HspBP1): increased levels of antiHspBP1 IgG are prevalent in HIV infected subjects. Journal of medical virology 76: 464-469.

78. Fillit, H., S. Shibata, T. Sasaki, H. Spiera, L. D. Kerr, and M. Blake. 1993. Autoantibodies to the protein core of vascular basement membrane heparan sulfate proteoglycan in systemic lupus erythematosus. Autoimmunity 14: 243-249.

79. Tiumentseva, M., V. Morozova, A. Zakabunin, D. Korobko, N. Malkova, M. Filipenko, and N. Tikunova. 2016. Use of the VH61 gene segment to code for anti-interleukin-18 autoantibodies in multiple sclerosis. Immunogenetics 68: 237-246.

80. Bremer, H. D., N. Landegren, R. Sjoberg, A. Hallgren, S. Renneker, E. Lattwein, D. Leonard, M. L. Eloranta, L. Ronnblom, G. Nordmark, P. Nilsson, G. Andersson, I. Lilliehook, K. Lindblad-Toh, O. Kampe, and H. Hansson-Hamlin. 2018. ILF2 and ILF3 are autoantigens in canine systemic autoimmune disease. Sci Rep 8: 4852.

81. Presslauer, S., G. Hinterhuber, K. Cauza, R. Horvat, K. Rappersberger, K. Wolff, and D. Foedinger. 2003. RasGAP-like protein IQGAP1 is expressed by human keratinocytes and recognized by autoantibodies in association with bullous skin disease. The Journal of investigative dermatology 120: 365-371. 
82. Idborg, H., A. Zandian, A. S. Sandberg, B. Nilsson, K. Elvin, L. Truedsson, A. Sohrabian, J. Rönnelid, J. Mo, G. Grosso, M. Kvarnström, I. Gunnarsson, J. Lehtiö, P. Nilsson, E. Svenungsson, and P. J. Jakobsson. 2019. Two subgroups in systemic lupus erythematosus with features of antiphospholipid or Sjögren's syndrome differ in molecular signatures and treatment perspectives. Arthritis research \& therapy 21: 62.

83. Targoff, I. N., E. P. Trieu, and F. W. Miller. 1993. Reaction of anti-OJ autoantibodies with components of the multi-enzyme complex of aminoacyl-tRNA synthetases in addition to isoleucyl-tRNA synthetase. The Journal of clinical investigation 91: 2556-2564.

84. Ola, T. O., P. A. Biro, M. I. Hawa, J. Ludvigsson, M. Locatelli, M. A. Puglisi, G. F. Bottazzo, and A. Fierabracci. 2006. Importin beta: a novel autoantigen in human autoimmunity identified by screening random peptide libraries on phage. Journal of autoimmunity 26: 197-207.

85. Dyachenko, L., K. Havrysh, A. Lytovchenko, I. Dosenko, S. Antoniuk, V. Filonenko, and R. Kiyamova. 2016. Autoantibody Response to ZRF1 and KRR1 SEREX Antigens in Patients with Breast Tumors of Different Histological Types and Grades. Disease markers 2016: 5128720.

86. Kain, R., H. Tadema, E. F. McKinney, A. Benharkou, R. Brandes, A. Peschel, V. Hubert, T. Feenstra, G. Sengölge, C. Stegeman, P. Heeringa, P. A. Lyons, K. G. Smith, C. Kallenberg, and A. J. Rees. 2012. High prevalence of autoantibodies to hLAMP-2 in anti-neutrophil cytoplasmic antibody-associated vasculitis. Journal of the American Society of Nephrology : JASN 23: 556566.

87. Ueda, K., T. Nakanishi, A. Shimizu, T. Takubo, and N. Matsuura. 2008. Identification of L-plastin autoantibody in plasma of patients with non-Hodgkin's lymphoma using a proteomics-based analysis. Ann Clin Biochem 45: 65-69.

88. Braunschweig, D., P. Krakowiak, P. Duncanson, R. Boyce, R. L. Hansen, P. Ashwood, I. Hertz-Picciotto, I. N. Pessah, and J. Van de Water. 2013. Autism-specific maternal autoantibodies recognize critical proteins in developing brain. Translational psychiatry 3: e277.

89. Konstantinov, K. N., Z. Galcheva-Gargova, M. Hoier-Madsen, A. Wiik, S. Ullman, P. Halberg, and G. L. Vejlsgaard. 1990. Autoantibodies to lamins $A$ and $C$ in sera of patients showing peripheral fluorescent antinuclear antibody pattern on HEP2 cells. The Journal of investigative dermatology 95: 304-308.

90. Brito, J., G. Biamonti, R. Caporali, and C. Montecucco. 1994. Autoantibodies to human nuclear lamin B2 protein. Epitope specificity in different autoimmune diseases. Journal of immunology (Baltimore, Md. : 1950) 153: 2268-2277.

91. Tanaka, M., M. Kishimura, S. Ozaki, F. Osakada, H. Hashimoto, M. Okubo, M. Murakami, and K. Nakao. 2000. Cloning of novel soluble gp130 and detection of its neutralizing autoantibodies in rheumatoid arthritis. The Journal of clinical investigation 106: 137-144.

92. Gadoth, A., T. J. Kryzer, J. Fryer, A. McKeon, V. A. Lennon, and S. J. Pittock. 2017. Microtubule-associated protein 1B: Novel paraneoplastic biomarker. Ann Neurol 81: 266-277.

93. Vermeulen, N., S. Vermeire, I. Arijs, G. Michiels, V. Ballet, R. Derua, E. Waelkens, L. Van Lommel, F. Schuit, P. Rutgeerts, and $X$. Bossuyt. 2011. Seroreactivity against glycolytic enzymes in inflammatory bowel disease. Inflammatory bowel diseases 17: 557-564.

94. Suzuki, K., T. Nagao, M. Itabashi, Y. Hamano, R. Sugamata, Y. Yamazaki, W. Yumura, S. Tsukita, P. C. Wang, T. Nakayama, and K. Suzuki. 2014. A novel autoantibody against moesin in the serum of patients with MPO-ANCA-associated vasculitis. Nephrol Dial Transplant 29: 1168-1177.

95. Marinou, D., G. Katsifis, G. Barouta, C. Liaskos, L. I. Sakkas, A. Tsakris, and J. G. Routsias. 2020. Major vault protein/lung resistance related protein: a novel biomarker for rheumatoid arthritis. Clinical and experimental rheumatology.

96. von Muhlen, C. A., E. K. Chan, C. L. Peebles, H. Imai, K. Kiyosawa, and E. M. Tan. 1995. Non-muscle myosin as target antigen for human autoantibodies in patients with hepatitis $C$ virus-associated chronic liver diseases. Clinical and experimental immunology 100: 67-74.

97. Zasońska, B. A., H. Hlídková, E. Petrovský, S. Myronovskij, T. Nehrych, N. Negrych, M. Shorobura, V. Antonyuk, R. Stoika, Y. Kit, and D. Horák. 2018. Monodisperse magnetic poly(glycidyl methacrylate) microspheres for isolation of autoantibodies with affinity for the $46 \mathrm{kDa}$ form of unconventional Myo1C present in autoimmune patients. Mikrochimica acta 185: 262.

98. Qin, Z., B. Lavingia, Y. Zou, and P. Stastny. 2011. Antibodies against nucleolin in recipients of organ transplants. Transplantation 92: 829-835.

99. Le Naour, F., F. Brichory, D. E. Misek, C. Brechot, S. M. Hanash, and L. Beretta. 2002. A distinct repertoire of autoantibodies in hepatocellular carcinoma identified by proteomic analysis. Molecular \& cellular proteomics : MCP 1: 197-203.

100. Liu, J., X. Xing, H. Huang, Y. Jiang, H. He, X. Xu, J. Yuan, L. Zhou, L. Yang, and Z. Zhuang. 2009. Identification of antigenic proteins associated with trichloroethylene-induced autoimmune disease by serological proteome analysis. Toxicology and applied pharmacology 240: 393-400.

101. Brankin, B., T. C. Skaar, M. Brotzman, B. Trock, and R. Clarke. 1998. Autoantibodies to the nuclear phosphoprotein nucleophosmin in breast cancer patients. Cancer Epidemiol Biomarkers Prev 7: 1109-1115.

102. Devaux, J. J., M. Odaka, and N. Yuki. 2012. Nodal proteins are target antigens in Guillain-Barré syndrome. Journal of the peripheral nervous system : JPNS 17: 62-71. 
103. Nagayama, S., T. Yokoi, H. Tanaka, Y. Kawaguchi, T. Shirasaka, and T. Kamataki. 1994. Occurrence of autoantibody to protein disulfide isomerase in patients with hepatic disorder. J Toxicol Sci 19: 163-169.

104. Becker, A., N. Ludwig, A. Keller, B. Tackenberg, C. Eienbroker, W. H. Oertel, K. Fassbender, E. Meese, and K. Ruprecht. 2013. Myasthenia gravis: analysis of serum autoantibody reactivities to 1827 potential human autoantigens by protein macroarrays. PloS one 8: e58095.

105. Houng, A. K., L. Maggini, C. Y. Clement, and G. L. Reed. 1997. Identification and structure of activated-platelet protein-1, a protein with RNA-binding domain motifs that is expressed by activated platelets. European journal of biochemistry 243: 209-218.

106. Kaneda, K., Y. Takasaki, K. Takeuchi, H. Yamada, M. Nawata, M. Matsushita, R. Matsudaira, K. Ikeda, K. Yamanaka, and H. Hashimoto. 2004. Autoimmune response to proteins of proliferating cell nuclear antigen multiprotein complexes in patients with connective tissue diseases. The Journal of rheumatology 31: 2142-2150.

107. Caorsi, C., E. Niccolai, M. Capello, R. Vallone, M. S. Chattaragada, B. Alushi, A. Castiglione, G. Ciccone, A. Mautino, P. Cassoni, L. De Monte, S. M. Álvarez-Fernández, A. Amedei, M. Alessio, and F. Novelli. 2016. Protein disulfide isomerase A3-specific Th1 effector cells infiltrate colon cancer tissue of patients with circulating anti-protein disulfide isomerase A3 autoantibodies. Transl Res 171: 17-28.e11-12.

108. Zhang, X., W. Shen, X. Dong, J. Fan, L. Liu, X. Gao, K. H. Kernstine, and L. Zhong. 2013. Identification of novel autoantibodies for detection of malignant mesothelioma. PloS one 8: e72458.

109. Chen, C., D. Liao, J. Wang, Z. Liang, and Q. Yao. 2014. Anti-human protein S antibody induces tissue factor expression through a direct interaction with platelet phosphofructokinase. Thrombosis research 133: 222-228.

110. Wieczorek, M., and A. Czernik. 2016. Paraneoplastic pemphigus: a short review. Clin Cosmet Investig Dermatol 9: $291-295$.

111. Mecoli, C. A., B. L. Adler, Q. Yang, L. K. Hummers, A. Rosen, L. Casciola-Rosen, and A. A. Shah. 2020. Cancer in Systemic Sclerosis: Analysis of Antibodies Against Components of the Th/To Complex. Arthritis \& rheumatology (Hoboken, N.J.).

112. Loshaj-Shala, A., M. Colzani, K. Brezovska, A. Poceva Panovska, L. Suturkova, and G. Beretta. 2018. Immunoproteomic identification of antigenic candidate Campylobacter jejuni and human peripheral nerve proteins involved in Guillain-Barré syndrome. Journal of neuroimmunology 317: 77-83.

113. Kratz, A., M. W. Harding, J. Craft, C. G. Mackworth-Young, and R. E. Handschumacher. 1992. Autoantibodies against cyclophilin in systemic lupus erythematosus and Lyme disease. Clinical and experimental immunology 90: 422-427.

114. Karasawa, R., S. Ozaki, K. Nishioka, and T. Kato. 2005. Autoantibodies to peroxiredoxin I and IV in patients with systemic autoimmune diseases. Microbiology and immunology 49: 57-65.

115. Lin, L. H., Y. W. Xu, L. S. Huang, C. Q. Hong, T. T. Zhai, L. D. Liao, W. J. Lin, L. Y. Xu, K. Zhang, E. M. Li, and Y. H. Peng. 2017. Serum proteomic-based analysis identifying autoantibodies against PRDX2 and PRDX3 as potential diagnostic biomarkers in nasopharyngeal carcinoma. Clin Proteomics 14: 6.

116. Kobayashi, S., T. Hiwasa, T. Arasawa, A. Kagaya, S. Ishii, H. Shimada, M. Ito, M. Suzuki, M. Kano, B. Rahmutulla, K. Kitamura, Y. Sawabe, H. Shin, M. Takiguchi, F. Nomura, H. Matsubara, and K. Matsushita. 2018. Identification of specific and common diagnostic antibody markers for gastrointestinal cancers by SEREX screening using testis CDNA phage library. Oncotarget 9 : 18559-18569.

117. Schild-Poulter, C., A. Su, A. Shih, O. P. Kelly, M. J. Fritzler, R. Goldstein, and R. J. Hache. 2008. Association of autoantibodies with $\mathrm{Ku}$ and DNA repair proteins in connective tissue diseases. Rheumatology (Oxford, England) 47: 165-171.

118. Heo, C. K., H. M. Hwang, W. H. Lim, H. J. Lee, J. S. Yoo, K. J. Lim, and E. W. Cho. 2020. Cyclic Peptide Mimotopes for the Detection of Serum Anti-ATIC Autoantibody Biomarker in Hepato-Cellular Carcinoma. International journal of molecular sciences 21.

119. Vaughan, J. H., J. R. Valbracht, M. D. Nguyen, H. H. Handley, R. S. Smith, K. Patrick, and G. H. Rhodes. 1995. Epstein-Barr virus-induced autoimmune responses. I. Immunoglobulin $M$ autoantibodies to proteins mimicking and not mimicking Epstein-Barr virus nuclear antigen-1. The Journal of clinical investigation 95: 1306-1315.

120. Luo, L. Y., I. Herrera, A. Soosaipillai, and E. P. Diamandis. 2002. Identification of heat shock protein 90 and other proteins as tumour antigens by serological screening of an ovarian carcinoma expression library. British journal of cancer 87: 339343.

121. Doe, K., K. Nozawa, K. Hiruma, Y. Yamada, Y. Matsuki, S. Nakano, M. Ogasawara, H. Nakano, T. Ikeda, T. Ikegami, M. Fujishiro, M. Kawasaki, K. Ikeda, H. Amano, S. Morimoto, H. Ogawa, K. Takamori, I. Sekigawa, and Y. Takasaki. 2014. Antibody against chromatin assembly factor-1 is a novel autoantibody specifically recognized in systemic lupus erythematosus. Lupus 23 : 1031-1041.

122. Wagatsuma, M., M. Kimura, R. Suzuki, F. Takeuchi, K. Matsuta, and H. Watanabe. 1996. Ezrin, radixin and moesin are possible auto-immune antigens in rheumatoid arthritis. Molecular immunology 33: 1171-1176.

123. Scofield, R. H., and J. B. Harley. 1991. Autoantigenicity of Ro/SSA antigen is related to a nucleocapsid protein of vesicular stomatitis virus. Proceedings of the National Academy of Sciences of the United States of America 88: 3343-3347.

124. Sato, T., T. Uchiumi, R. Kominami, and M. Arakawa. 1990. Autoantibodies specific for the 20-KDal ribosomal large subunit protein L12. Biochemical and biophysical research communications 172: 496-502. 
125. Absi, M., J. P. La Vergne, A. Marzouki, F. Giraud, D. Rigal, A. M. Reboud, J. P. Reboud, and J. C. Monier. 1989. Heterogeneity of ribosomal autoantibodies from human, murine and canine connective tissue diseases. Immunology letters 23: 35-41.

126. Guialis, A., M. Patrinou-Georgoula, N. Tsifetaki, V. Aidinis, C. E. Sekeris, and H. M. Moutsopoulos. 1994. Anti-5S RNA/protein (RNP) antibody levels correlate with disease activity in a patient with systemic lupus erythematosus (SLE) nephritis. Clinical and experimental immunology 95: 385-389.

127. Frampton, G., S. Moriya, J. D. Pearson, D. A. Isenberg, F. J. Ward, T. A. Smith, A. Panayiotou, N. A. Staines, and J. J. Murphy. 2000. Identification of candidate endothelial cell autoantigens in systemic lupus erythematosus using a molecular cloning strategy: a role for ribosomal P protein PO as an endothelial cell autoantigen. Rheumatology (Oxford, England) 39: 11141120.

128. Neu, E., A. H. von Mikecz, P. H. Hemmerich, H. H. Peter, M. Fricke, H. Deicher, E. Genth, and U. Krawinkel. 1995. Autoantibodies against eukaryotic protein $\mathrm{L7}$ in patients suffering from systemic lupus erythematosus and progressive systemic sclerosis: frequency and correlation with clinical, serological and genetic parameters. The SLE Study Group. Clinical and experimental immunology 100: 198-204.

129. Elkon, K., E. Bonfa, R. Llovet, W. Danho, H. Weissbach, and N. Brot. 1988. Properties of the ribosomal P2 protein autoantigen are similar to those of foreign protein antigens. Proceedings of the National Academy of Sciences of the United States of America 85: 5186-5189.

130. Elkon, K., H. Weissbach, and N. Brot. 1990. Central nervous system function in systemic lupus erythematosus. Neurochemical research 15: 401-406.

131. Tycowski, K. T., M. D. Shu, and J. A. Steitz. 1993. A small nucleolar RNA is processed from an intron of the human gene encoding ribosomal protein S3. Genes \& development 7: 1176-1190.

132. Qiu, J., G. Choi, L. Li, H. Wang, S. J. Pitteri, S. R. Pereira-Faca, A. L. Krasnoselsky, T. W. Randolph, G. S. Omenn, C. Edelstein, M. J. Barnett, M. D. Thornquist, G. E. Goodman, D. E. Brenner, Z. Feng, and S. M. Hanash. 2008. Occurrence of autoantibodies to annexin I, 14-3-3 theta and LAMR1 in prediagnostic lung cancer sera. Journal of clinical oncology : official journal of the American Society of Clinical Oncology 26: 5060-5066.

133. Yang, J. M., B. Hildebrandt, C. Luderschmidt, and K. M. Pollard. 2003. Human scleroderma sera contain autoantibodies to protein components specific to the U3 small nucleolar RNP complex. Arthritis and rheumatism 48: 210-217.

134. Kaji, K., N. Fertig, T. A. Medsger, Jr., T. Satoh, K. Hoshino, Y. Hamaguchi, M. Hasegawa, M. Lucas, A. Schnure, F. Ogawa, S. Sato, K. Takehara, M. Fujimoto, and M. Kuwana. 2014. Autoantibodies to RuvBL1 and RuvBL2: a novel systemic sclerosisrelated antibody associated with diffuse cutaneous and skeletal muscle involvement. Arthritis care \& research 66: 575-584.

135. Hwang, H. M., C. K. Heo, H. J. Lee, S. S. Kwak, W. H. Lim, J. S. Yoo, D. Y. Yu, K. J. Lim, J. Y. Kim, and E. W. Cho. 2018. Identification of anti-SF3B1 autoantibody as a diagnostic marker in patients with hepatocellular carcinoma. J Transl Med 16: 177.

136. Kistner, A., M. B. Bigler, K. Glatz, S. B. Egli, F. S. Baldin, F. A. Marquardsen, M. Mehling, K. M. Rentsch, D. Staub, M. Aschwanden, M. Recher, T. Daikeler, and C. T. Berger. 2017. Characteristics of autoantibodies targeting 14-3-3 proteins and their association with clinical features in newly diagnosed giant cell arteritis. Rheumatology (Oxford, England) 56: 829-834.

137. Chumpitazi, B. F., L. Bouillet, M. T. Drouet, L. Kuhn, J. Garin, J. P. Zarski, and C. Drouet. 2009. Biological autoimmunity screening in hepatitis $C$ patients by anti-HepG2 lysate and anti-heat shock protein 70.1 autoantibodies. European journal of clinical microbiology \& infectious diseases : official publication of the European Society of Clinical Microbiology 28: 137146.

138. Kubo, M., H. Ihn, M. Kuwana, Y. Asano, T. Tamaki, K. Yamane, and K. Tamaki. 2002. Anti-U5 snRNP antibody as a possible serological marker for scleroderma-polymyositis overlap. Rheumatology (Oxford, England) 41: 531-534.

139. Yamamoto, A. M., Z. Amoura, C. Johannet, A. L. Jeronimo, H. Campos, S. Koutouzov, J. C. Piette, and J. F. Bach. 2000. Quantitative radioligand assays using de novo-synthesized recombinant autoantigens in connective tissue diseases: new tools to approach the pathogenic significance of anti-RNP antibodies in rheumatic diseases. Arthritis and rheumatism 43: 689-698.

140. Huntriss, J. D., D. S. Latchman, and D. G. Williams. 1993. Lupus autoantibodies discriminate between the highly homologous Sm polypeptides B/B' and SmN by binding an epitope restricted to B/B'. Clinical and experimental immunology 92: 263-267.

141. Brahms, H., J. Raymackers, A. Union, F. de Keyser, L. Meheus, and R. Luhrmann. 2000. The C-terminal RG dipeptide repeats of the spliceosomal Sm proteins D1 and D3 contain symmetrical dimethylarginines, which form a major B-cell epitope for anti-Sm autoantibodies. The Journal of biological chemistry 275: 17122-17129.

142. McClain, M. T., P. A. Ramsland, K. M. Kaufman, and J. A. James. 2002. Anti-sm autoantibodies in systemic lupus target highly basic surface structures of complexed spliceosomal autoantigens. Journal of immunology (Baltimore, Md. : 1950) 168: 20542062.

143. van Blitterswijk, M., S. Gulati, E. Smoot, M. Jaffa, N. Maher, B. T. Hyman, A. J. Ivinson, C. R. Scherzer, D. A. Schoenfeld, M. E. Cudkowicz, R. H. Brown, Jr., and D. A. Bosco. 2011. Anti-superoxide dismutase antibodies are associated with survival in patients with sporadic amyotrophic lateral sclerosis. Amyotrophic lateral sclerosis : official publication of the World Federation of Neurology Research Group on Motor Neuron Diseases 12: 430-438. 
144. Garbarz, M., D. Dhermy, O. Bournier, A. Bezeaud, and P. Boivin. 1981. Anti-spectrin in sera containing smooth muscle autoantibodies from patients with chronic active hepatitis. Clinical and experimental immunology 43: 87-93.

145. Zaninoni, A., C. Vercellati, F. G. Imperiali, A. P. Marcello, B. Fattizzo, E. Fermo, P. Bianchi, C. Grossi, A. Cattaneo, A. Cortelezzi, A. Zanella, and W. Barcellini. 2015. Detection of red blood cell antibodies in mitogen-stimulated cultures from patients with hereditary spherocytosis. Transfusion 55: 2930-2938.

146. Utz, P. J., M. Hottelet, T. M. Le, S. J. Kim, M. E. Geiger, W. J. van Venrooij, and P. Anderson. 1998. The 72-kDa component of signal recognition particle is cleaved during apoptosis. The Journal of biological chemistry 273: 35362-35370.

147. Lipes, B. D., and J. D. Keene. 2002. Autoimmune epitopes in messenger RNA. RNA (New York, N. Y.) 8: 762-771.

148. Santoro, P., M. De Andrea, G. Migliaretti, C. Trapani, S. Landolfo, and M. Gariglio. 2002. High prevalence of autoantibodies against the nuclear high mobility group (HMG) protein SSRP1 in sera from patients with systemic lupus erythematosus, but not other rheumatic diseases. The Journal of rheumatology 29: 90-93.

149. Cortini, A., S. Bembich, L. Marson, E. Cocco, and P. Edomi. 2019. Identification of novel non-myelin biomarkers in multiple sclerosis using an improved phage-display approach. PloS one 14: e0226162.

150. Niland, B., G. Miklossy, K. Banki, W. E. Biddison, L. Casciola-Rosen, A. Rosen, D. Martinvalet, J. Lieberman, and A. Perl. 2010. Cleavage of transaldolase by granzyme $B$ causes the loss of enzymatic activity with retention of antigenicity for multiple sclerosis patients. Journal of immunology (Baltimore, Md. : 1950) 184: 4025-4032.

151. Lee, Y. J., W. H. Ting, Y. W. Yang, C. J. Lin, Y. T. Hsieh, C. Y. Huang, F. S. Lo, C. C. Chu, C. L. Lin, W. S. Lin, and T. S. Lai. 2020. HLA-DQ genotype and biochemical characterization of anti-transglutaminase 2 antibodies in patients with type 1 diabetes mellitus in Taiwan. FASEB journal : official publication of the Federation of American Societies for Experimental Biology 34: 8459-8474.

152. Muto, M., M. Mori, T. Hiwasa, M. Takiguchi, Y. Iwadate, A. Uzawa, T. Uchida, H. Masuda, K. Sugimoto, and S. Kuwabara. 2015. Novel serum autoantibodies against talin1 in multiple sclerosis: Possible pathogenetic roles of the antibodies. Journal of neuroimmunology 284: 30-36.

153. Mariampillai, K., B. Granger, D. Amelin, M. Guiguet, E. Hachulla, F. Maurier, A. Meyer, A. Tohmé, J. L. Charuel, L. Musset, Y. Allenbach, and O. Benveniste. 2018. Development of a New Classification System for Idiopathic Inflammatory Myopathies Based on Clinical Manifestations and Myositis-Specific Autoantibodies. JAMA neurology 75: 1528-1537.

154. Geng, X., L. Biancone, H. H. Dai, J. J. Lin, N. Yoshizaki, A. Dasgupta, F. Pallone, and K. M. Das. 1998. Tropomyosin isoforms in intestinal mucosa: production of autoantibodies to tropomyosin isoforms in ulcerative colitis. Gastroenterology 114: 912-922.

155. Gajbhiye, R., A. Sonawani, S. Khan, A. Suryawanshi, S. Kadam, N. Warty, V. Raut, and V. Khole. 2012. Identification and validation of novel serum markers for early diagnosis of endometriosis. Hum Reprod 27: 408-417.

156. Kimura, A., T. Sakurai, M. Yamada, A. Koumura, Y. Hayashi, Y. Tanaka, I. Hozumi, H. Ohtaki, M. Chousa, M. Takemura, M. Seishima, and T. Inuzuka. 2012. Anti-endothelial cell antibodies in patients with cerebral small vessel disease. Curr Neurovasc Res 9: 296-301.

157. Zhao, X., Y. Cheng, Y. Gan, R. Jia, L. Zhu, and X. Sun. 2018. Anti-tubulin-alpha-1C autoantibody in systemic lupus erythematosus: a novel indicator of disease activity and vasculitis manifestations. Clinical rheumatology 37: $1229-1237$.

158. Matthes, T., A. Wolff, P. Soubiran, F. Gros, and G. Dighiero. 1988. Antitubulin antibodies. II. Natural autoantibodies and induced antibodies recognize different epitopes on the tubulin molecule. Journal of immunology (Baltimore, Md. : 1950) 141: 3135-3141.

159. Prasannan, L., D. E. Misek, R. Hinderer, J. Michon, J. D. Geiger, and S. M. Hanash. 2000. Identification of beta-tubulin isoforms as tumor antigens in neuroblastoma. Clinical cancer research : an official journal of the American Association for Cancer Research 6: 3949-3956.

160. Muro, Y., Y. Ogawa, Y. Kato, and M. Hagiwara. 1998. Autoantibody to thioredoxin reductase in an ovarian cancer patient. Biochemical and biophysical research communications 242: 267-271.

161. Betteridge, Z. E., H. Gunawardena, H. Chinoy, J. North, W. E. Ollier, R. G. Cooper, N. J. McHugh, and U. K. A. O. M. I. Collaboration. 2009. Clinical and human leucocyte antigen class II haplotype associations of autoantibodies to small ubiquitin-like modifier enzyme, a dermatomyositis-specific autoantigen target, in UK Caucasian adult-onset myositis. Annals of the rheumatic diseases 68: 1621-1625.

162. Almamy, A., C. Schwerk, H. Schroten, H. Ishikawa, A. R. Asif, and B. Reuss. 2017. Interactions of antisera to different Chlamydia and Chlamydophila species with the ribosomal protein RPS27a correlate with impaired protein synthesis in a human choroid plexus papilloma cell line. Immunologic research 65: 1110-1123.

163. Pluta, A. F., and W. C. Earnshaw. 1996. Specific interaction between human kinetochore protein CENP-C and a nucleolar transcriptional regulator. The Journal of biological chemistry 271: 18767-18774.

164. Li, X., J. Sun, R. Mu, Y. Gan, G. Wang, J. He, L. Yi, Q. Wang, X. Sun, and Z. Li. 2019. The clinical significance of ubiquitin carboxyl hydrolase L1 and its autoantibody in neuropsychiatric systemic lupus erythematosus. Clinical and experimental rheumatology 37: 474-480.

165. Zhou, Y., J. Cui, and H. Du. 2019. Autoantibody-targeted TAAs in pancreatic cancer: A comprehensive analysis. Pancreatology 19: 760-768. 
166. Miyachi, K., H. Hosaka, N. Nakamura, H. Miyakawa, T. Mimori, M. Shibata, S. Matsushima, H. Chinoh, T. Horigome, R. W. Hankins, M. Zhang, and M. J. Fritzler. 2006. Anti-p97/VCP antibodies: an autoantibody marker for a subset of primary biliary cirrhosis patients with milder disease? Scand J Immunol 63: 376-382.

167. Li, F. J., R. Surolia, H. Li, Z. Wang, T. Kulkarni, G. Liu, J. A. de Andrade, D. J. Kass, V. J. Thannickal, S. R. Duncan, and V. B. Antony. 2017. Autoimmunity to Vimentin Is Associated with Outcomes of Patients with Idiopathic Pulmonary Fibrosis. Journal of immunology (Baltimore, Md. : 1950) 199: 1596-1605.

168. Mimori, T., Y. Ohosone, N. Hama, A. Suwa, M. Akizuki, M. Homma, A. J. Griffith, and J. A. Hardin. 1990. Isolation and characterization of cDNA encoding the $80-\mathrm{kDa}$ subunit protein of the human autoantigen $\mathrm{Ku}(\mathrm{p} 70 / \mathrm{p} 80$ ) recognized by autoantibodies from patients with scleroderma-polymyositis overlap syndrome. Proceedings of the National Academy of Sciences of the United States of America 87: 1777-1781.

169. Hoa, S., M. Hudson, Y. Troyanov, S. Proudman, J. Walker, W. Stevens, M. Nikpour, S. Assassi, M. D. Mayes, M. Wang, M. Baron, M. J. Fritzler, G. Canadian Scleroderma Research, G. Australian Scleroderma Interest, and S. Genetics versus Environment in Scleroderma Outcome. 2016. Single-specificity anti-Ku antibodies in an international cohort of 2140 systemic sclerosis subjects: clinical associations. Medicine (Baltimore) 95: e4713.

170. Morgenroth, R., C. Reichardt, J. Steffen, S. Busse, R. Frank, H. Heidecke, and P. R. Mertens. 2020. Autoantibody Formation and Mapping of Immunogenic Epitopes against Cold-Shock-Protein YB-1 in Cancer Patients and Healthy Controls. Cancers 12.

171. Braunschweig, D., P. Krakowiak, P. Duncanson, R. Boyce, R. L. Hansen, P. Ashwood, I. Hertz-Picciotto, I. N. Pessah, and J. Van de Water. 2013. Autism-specific maternal autoantibodies recognize critical proteins in developing brain. Translational psychiatry 3: e277.

172. van Beers-Tas, M. H., A. Marotta, M. Boers, W. P. Maksymowych, and D. van Schaardenburg. 2016. A prospective cohort study of 14-3-3eta in ACPA and/or RF-positive patients with arthralgia. Arthritis research \& therapy 18: 76.

173. Chakravarti, R., K. Gupta, M. Swain, B. Willard, J. Scholtz, L. G. Svensson, E. E. Roselli, G. Pettersson, D. R. Johnston, E. G. Soltesz, M. Yamashita, D. Stuehr, T. M. Daly, and G. S. Hoffman. 2015. 14-3-3 in Thoracic Aortic Aneurysms: Identification of a Novel Autoantigen in Large Vessel Vasculitis. Arthritis \& rheumatology (Hoboken, N.J.) 67: 1913-1921. 
bioRxiv preprint doi: https://doi.org/10.1101/2021.02 21.432171. this version posted February 22 2021. The copyright holder for this preprint (which was not certified by peer review) is the author/funder, who has granted bioRxiv a license to display the preprint in perpetuity. It is made available under aCC-BY 4.0 International license.

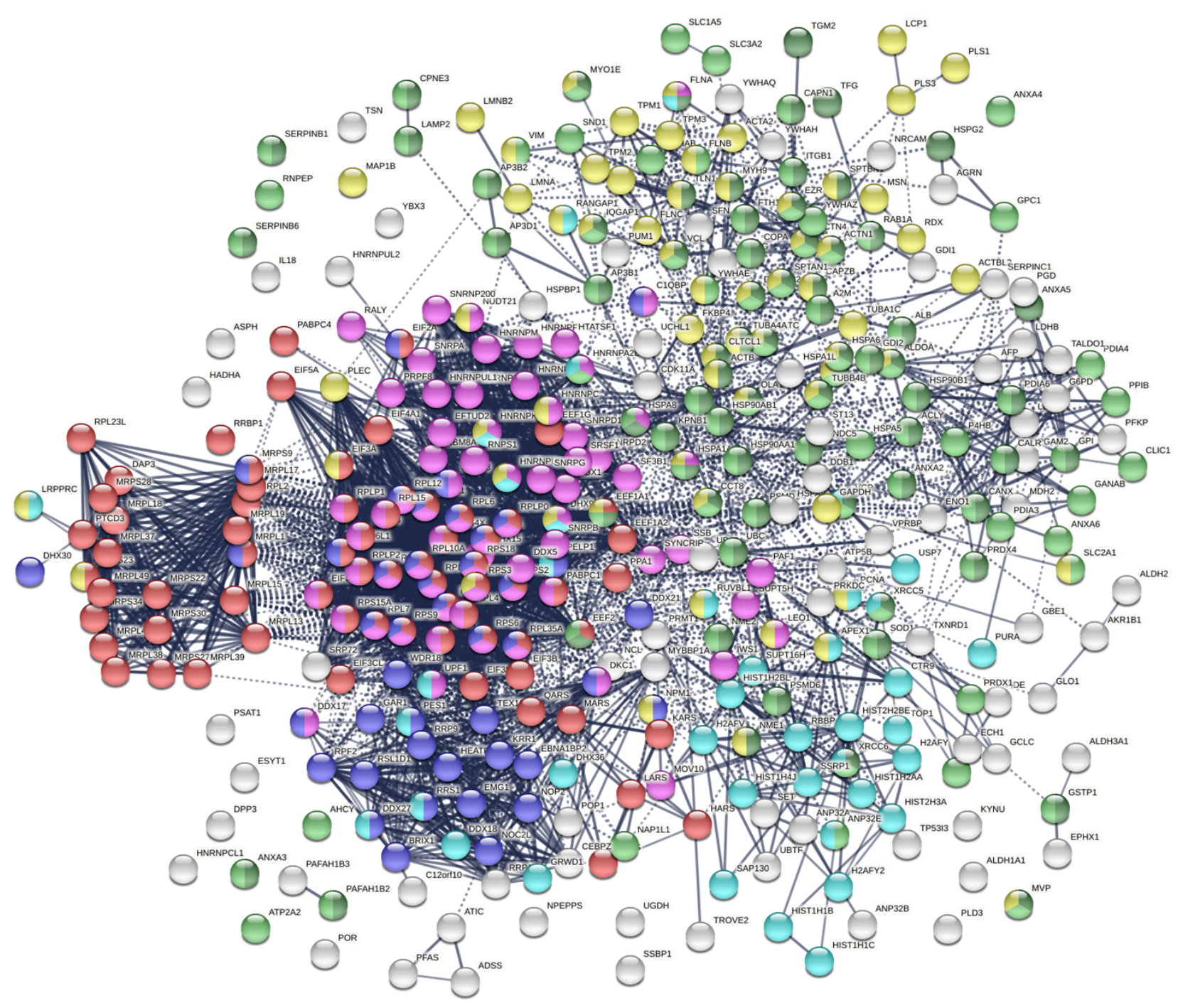

Fig. 1. The autoantigenome from A549 cells identified by DS affinity. Marked proteins are associated with translation (69 proteins, red), mRNA metabolic processing (69 proteins, pink), ribosome biogenesis (43 proteins, blue), vesicle (87 proteins, green) and vesicle-mediated transport (72 proteins, dark green), chromosomes (40 proteins, aqua), and cytoskeleton (65 proteins, gold). 
bioRxiv preprint doi: https://doi org/10.1101/2021.02 21.432171; this version posted February 22, 2021. The copyright holder for this preprint (which was not certified by peer review) is the author/funder, who has granted bioRxiv a license to display the preprint in perpetuity. It is made available under aCC-BY 4.0 International license.

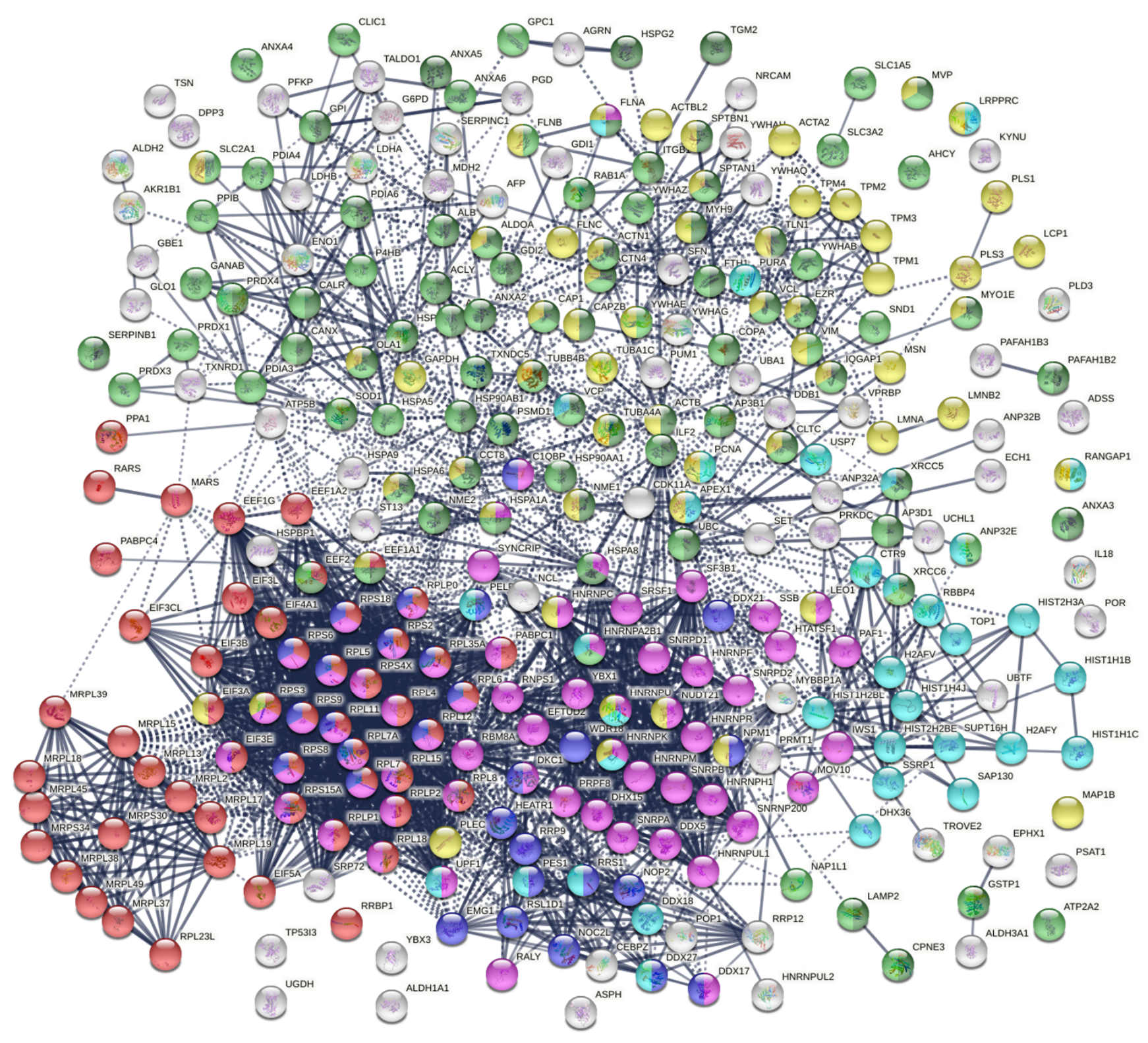

Fig. 2. COVID-altered proteins shared with the A549 autoantigenome. Marked proteins are associated with translation (53 proteins, red), mRNA metabolic process (63 proteins, pink), vesicle (79 proteins, green) and vesicle-mediated transport (64 proteins, dark green), cytoskeleton (58 proteins, gold), chromosomes (35 proteins, aqua), and ribosome biogenesis (29 proteins, blue). 
bioRxiv preprint doi: https://doi.org/10.1101/2021.02.21.432171; this version posted February 22, 2021. The copyright holder for this preprint (which was not certified by peer review) is the author/funder, who has granted bioRxiv a license to display the preprint in perpetuity. It is made available under aCC-BY 4.0 International license.

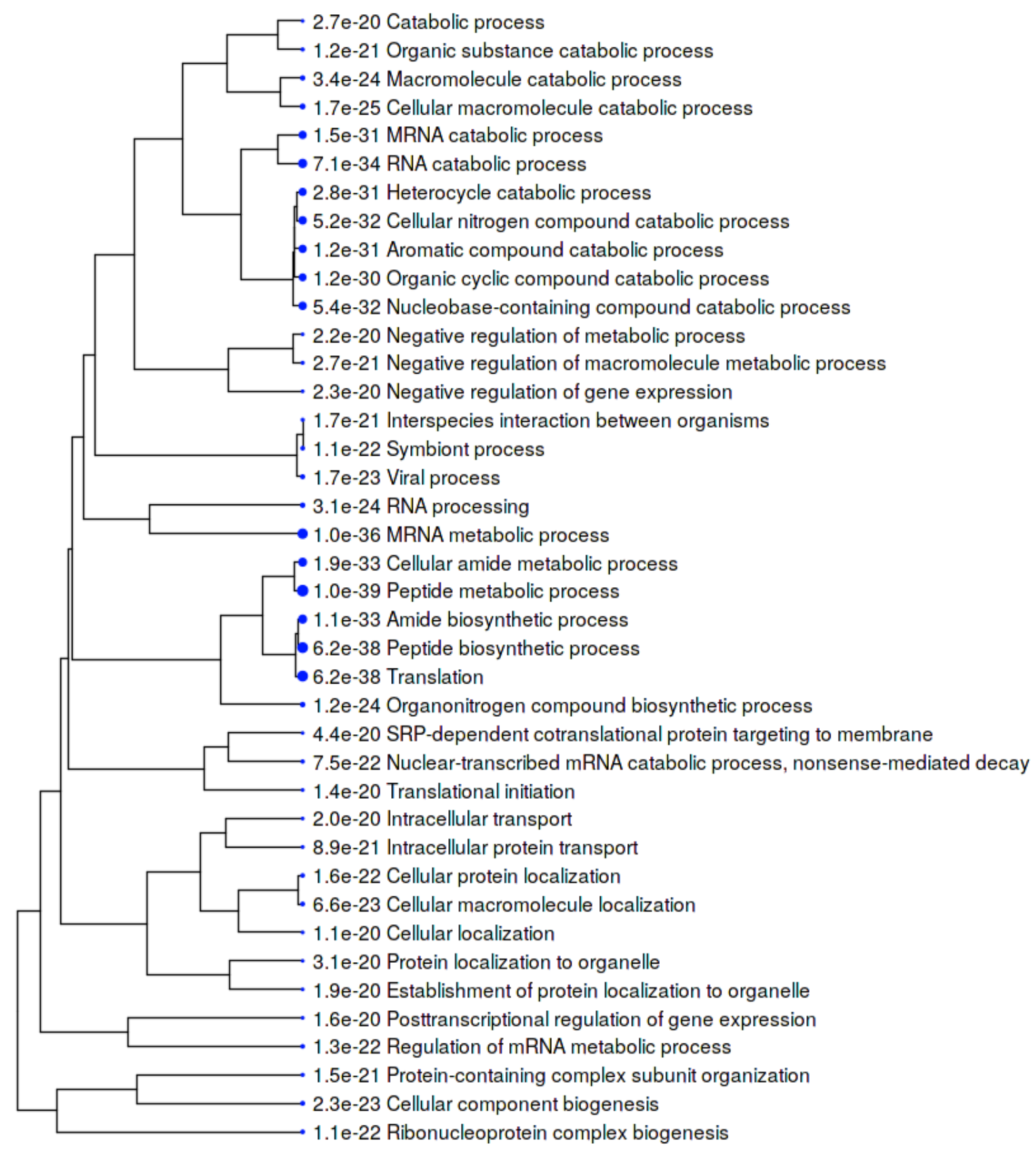

Fig. 3. Top 40 enriched $\mathrm{GO}$ biological processes among COVID-altered proteins shared with the A549 autoantigenome. Bigger dots indicate more significant P-values. 
bioRxiv preprint doi: https://doi.org/10.1101/2021.02.21.432171; this version posted February 22, 2021. The copyright holder for this preprint (which was not certified by peer review) is the author/funder, who has granted bioRxiv a license to display the preprint in perpetuity. It is made available under aCC-BY 4.0 International license.

\section{COVID-altered}

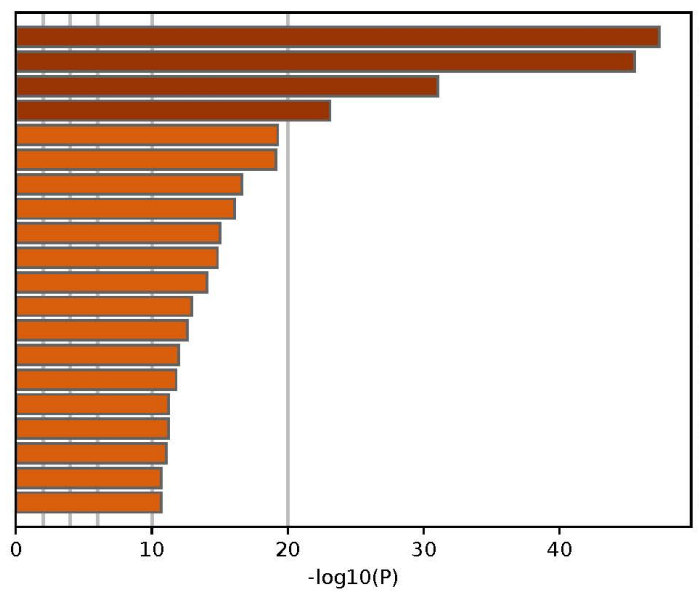

GO:0043043: peptide biosynthetic process R-HSA-8953854: Metabolism of RNA

GO:0022613: ribonucleoprotein complex biogenesis

CORUM:1181: C complex spliceosome

GO:0045055: regulated exocytosis

GO:0006414: translational elongation

GO:0071826: ribonucleoprotein complex subunit organization

CORUM:1223: H2AX complex, isolated from cells without IR exposure

GO:0002181: cytoplasmic translation

GO:0034248: regulation of cellular amide metabolic process

GO:0006457: protein folding

M66: PID MYC ACTIV PATHWAY

CORUM:1332: Large Drosha complex

GO:0071103: DNA conformation change

GO:1903827: regulation of cellular protein localization

CORUM:1335: SNW1 complex

GO:0006913: nucleocytoplasmic transport

R-HSA-114608: Platelet degranulation

R-HSA-447115: Interleukin-12 family signaling

GO:0000723: telomere maintenance

\section{Up-regulated}

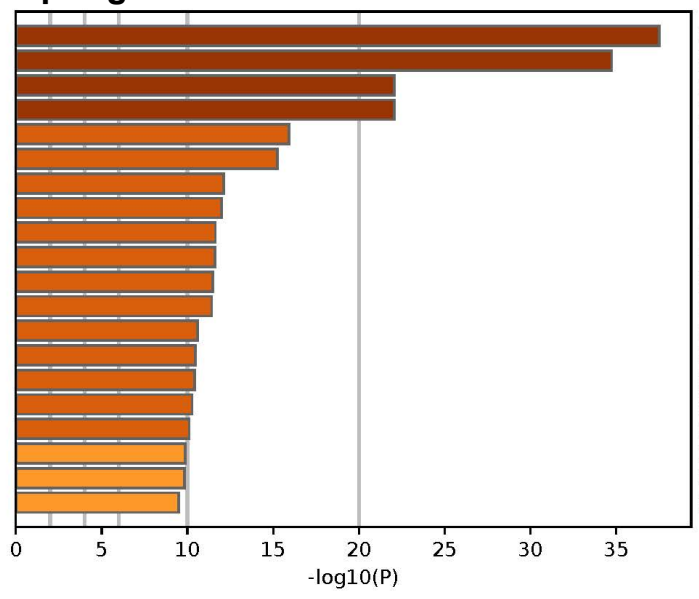

CORUM:3055: Nop56p-associated pre-rRNA complex GO:0006401: RNA catabolic process GO:0045055: regulated exocytosis

GO:0022613: ribonucleoprotein complex biogenesis

CORUM:1181: C complex spliceosome

GO:0006457: protein folding

CORUM:3082: DGCR8 multiprotein complex

GO:0042273: ribosomal large subunit biogenesis

M66: PID MYC ACTIV PATHWAY

R-HSA-5653656: Vesicle-mediated transport

GO:0002181: cytoplasmic translation

R-HSA-114608: Platelet degranulation

CORUM:5613: Emerin complex 25

R-HSA-445355: Smooth Muscle Contraction

R-HSA-447115: Interleukin-12 family signaling

GO:0045454: cell redox homeostasis

GO:0000723: telomere maintenance

CORUM:1223: H2AX complex, isolated from cells without IR exposure

GO:0006913: nucleocytoplasmic transport

R-HSA-373760: LICAM interactions

\section{Down-regulated}

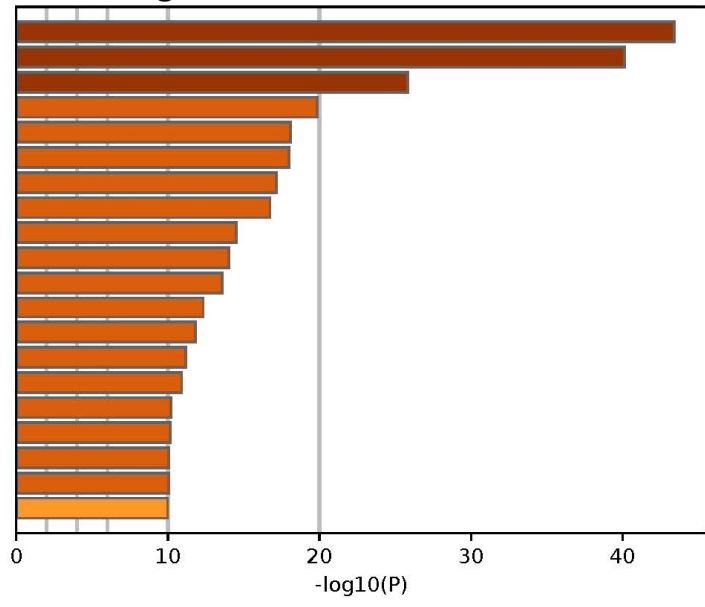

GO:0006412: translation

R-HSA-8953854: Metabolism of RNA

GO:0022613: ribonucleoprotein complex biogenesis

CORUM:1181: C complex spliceosome

GO:0042254: ribosome biogenesis

GO:0006414: translational elongation

GO:0045055: regulated exocytosis

CORUM:1223: H2AX complex, isolated from cells without IR exposure

GO:0006457: protein folding

GO:0006417: regulation of translation

GO:0002181: cytoplasmic translation

CORUM:5199: Kinase maturation complex 1

CORUM:1335: SNW1 complex

M66: PID MYC ACTIV PATHWAY

R-HSA-114608: Platelet degranulation

GO:0042273: ribosomal large subunit biogenesis

R-HSA-445355: Smooth Muscle Contraction

R-HSA-447115: Interleukin-12 family signaling

GO:0006913: nucleocytoplasmic transport

GO:0060249: anatomical structure homeostasis

$-\log 10(\mathrm{P})$

Fig. 4. Top 20 enriched pathways and processes among COVID-altered autoAgs. Top: 298 COVIDaltered autoAgs. Middle: 231 up-regulated autoAgs in COVID. Bottom: 252 down-regulated autoAgs in COVID. 


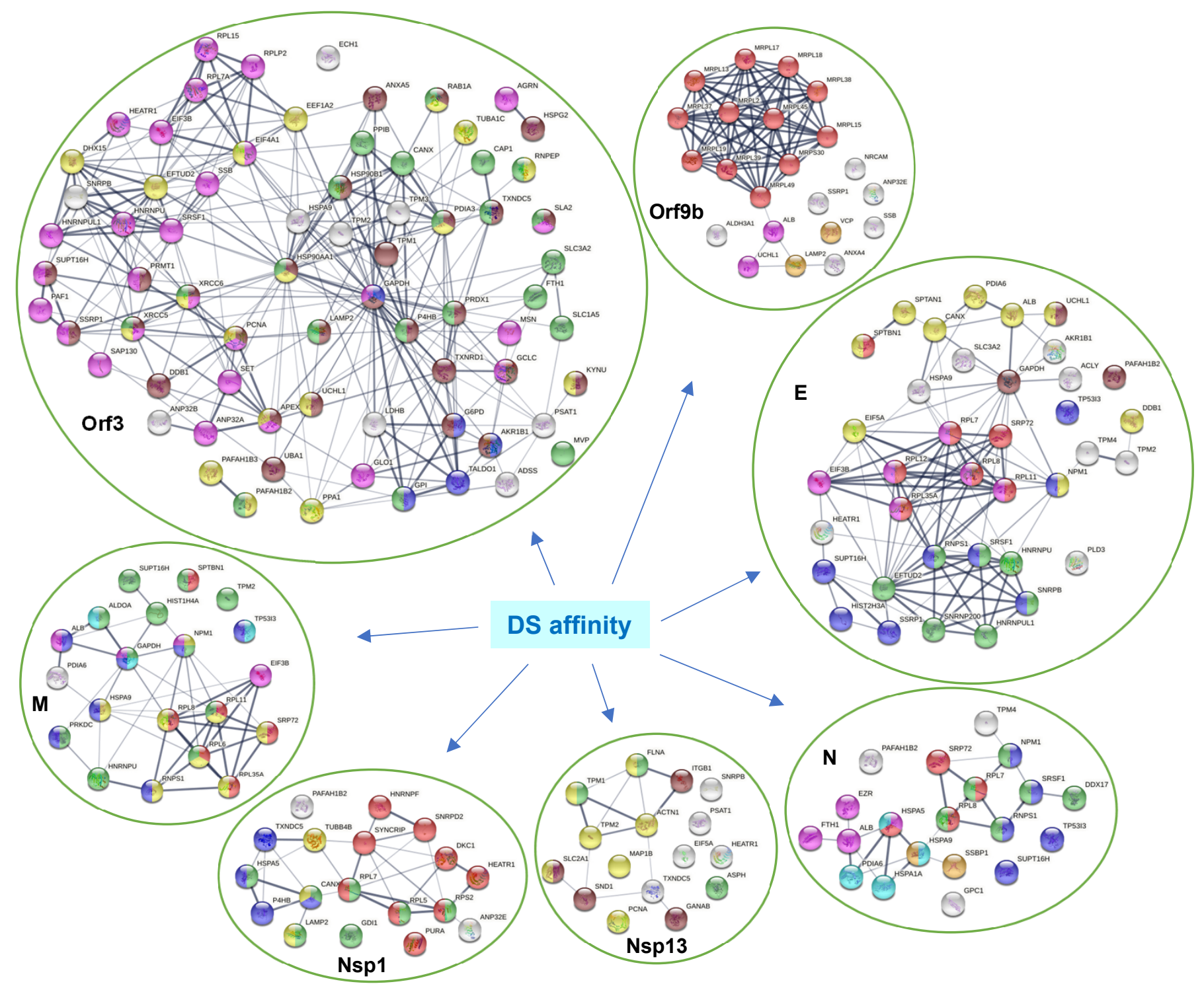

Fig. 5. DS-affinity proteins that interact with SARS-CoV-2 viral proteins or are perturbed in A549 cells expressing individual viral proteins. Orf3: regulation of gene expression (pink), cytoplasmic vesicle (green), monosaccharide biosynthetic process (blue), response to stress (brown), and hydrolase activity (gold). Orf9b: mitochondrial translation (red), mitochondrion localization (pink), autophagosome maturation (gold). E: establishment of protein localization to membrane (red), translation initiation (pink), mRNA splicing (green), regulation of macroautophagy (brown), post-translational protein modification (gold), RNA polymerase II transcription (blue). M: establishment of protein localization to membrane (red), intracellular protein transport (gold), organelle organization (green), nicotinamide nucleotide metabolic process (aqua), regulation of apoptotic process (blue), and symbiont process (pink). N: maintenance of location in cell (pink), protein localization to ER (red), protein folding (aqua), mitochondrial nucleoid (amber), RNA polymerase II transcription (blue), and RNA-binding (green). Nsp1: protein localization (green), gene expression (red), protein processing in ER (blue), and phagosome (gold). Nsp13: cytoskeleton (gold), regulation of muscle contraction (green), and melanosome (brown). 
bioRxiv preprint doi: https://doi.org/10.1101/2021.02 21.432171. this version posted February 22 2021. The copyright holder for this preprint (which was not certified by peer review) is the author/funder, who has granted bioRxiv a license to display the preprint in perpetuity. It is made available under aCC-BY 4.0 International license.

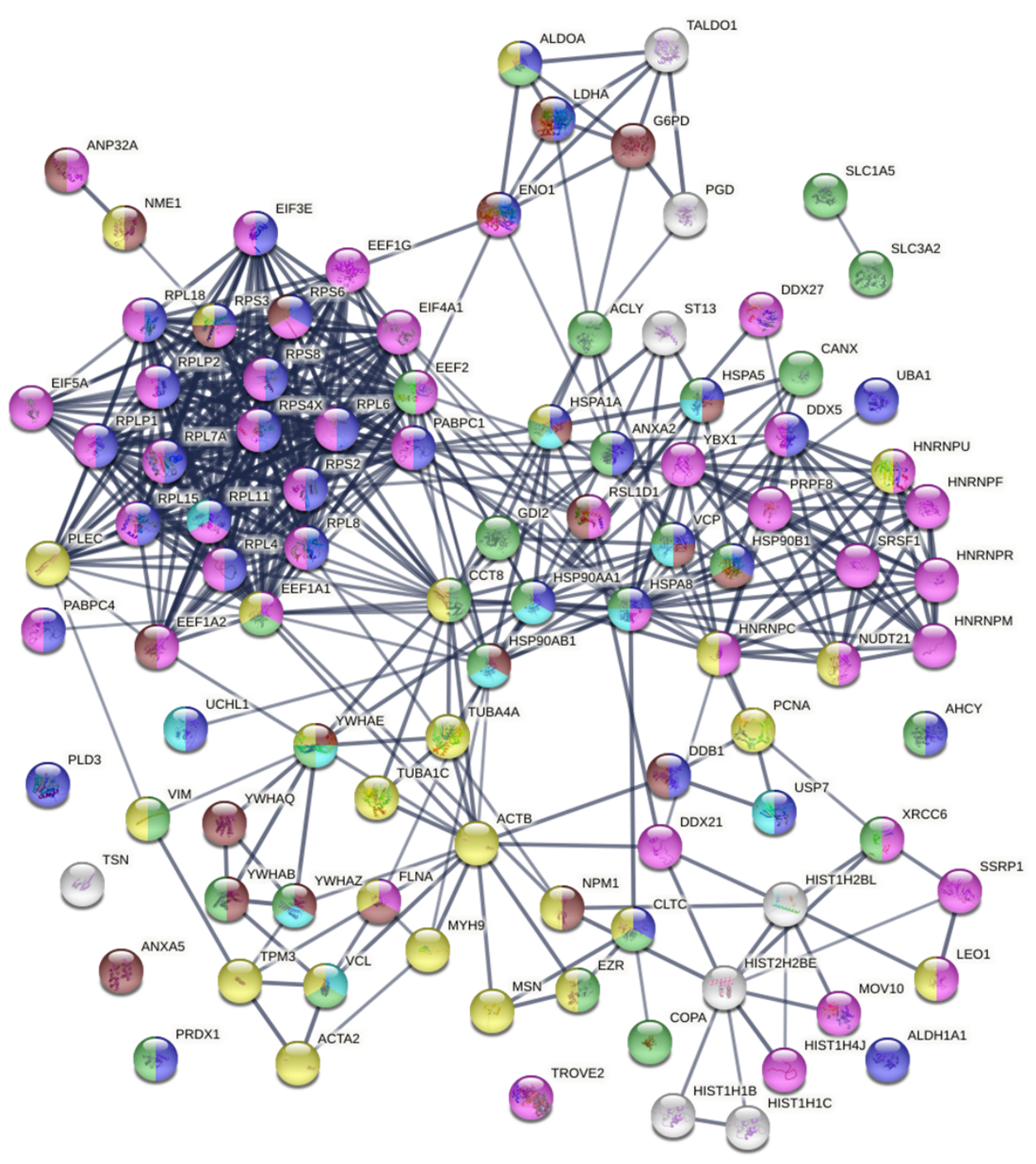

Fig. 6. Known and putative autoAgs derived from ubiquitination alteration in SARS-CoV-2 infected AF549 cells. Marked proteins are associated with catabolic process (37 proteins, blue), ubiquitin protein ligase binding (12 proteins, aqua), gene expression (46 proteins, pink), regulation of apoptotic process (22 proteins, brown), cytoplasmic vesicles (28 proteins, green), and cytoskeleton (26 proteins, gold). 
bioRxiv preprint doi: httos://doi. org/10 1101/2021 0221432171 this version posted February 222021 The copvriaht holder for this preprint (which was not certified by peer review) is the author/funder, who has granted bioRxiv a license to display the preprint in perpetuity. It is made available under aCC-BY 4.0 International license.

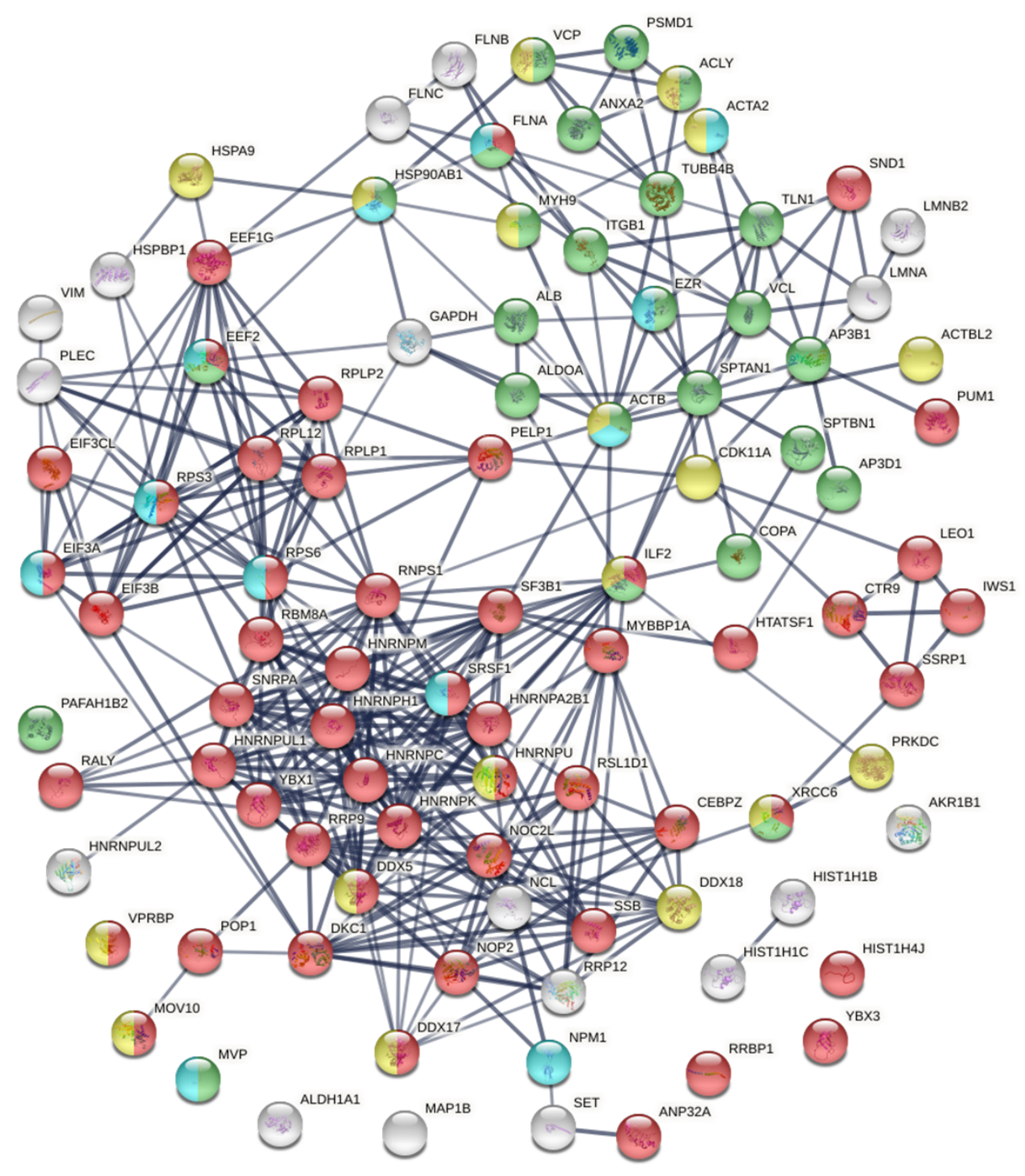

Fig. 7. Known and putative autoAgs derived from phosphorylation alteration in SARS-CoV-2 infected cells. Marked proteins are associated with gene expression (52 proteins, red), vesiclemediated transport (25 proteins, green), ATP binding (18 proteins, gold), and kinase binding (12 proteins, aqua). 